LBL-35336

\title{
A Review of China's Energy Policy
}

\author{
YANG Fuqiang, \\ DUAN Ning, ${ }^{\text {tt }}$ HUAN Zhijie, ${ }^{\dagger \dagger}$ Mark D. Levine, \\ Nathan C. Martin," Jonathan E. Sinton," WANG Qingyi, ${ }^{\dagger}$ \\ ZHOU Dadi, ${ }^{\dagger}$ ZHOU Fenqi,$" \dagger$ and ZHU Chengzhang ${ }^{\dagger}$
}

This work was supported by the Office of the Assistant Secretary for Policy, Planning and Program Evaluation, U.S. Department of Energy under Contract No. DE-AC0376SF00098

- Lawrence Berkeley Laboratory, Berkeley, Califomia, U. S. A.

$+\quad$ China Energy Research Society, Beijing, China

tt Energy Research Institute, SPC, Beijing, China

$\mathrm{tH}$ Environment Management Institute, Beijing, China 


\section{DISCLAIMER}

This report was prepared as an account of work sponsored by an agency of the United States Government. Neither the United States Government nor any agency thereof, nor any of their employees, make any warranty, express or implied, or assumes any legal liability or responsibility for the accuracy, completeness, or usefulness of any information, apparatus, product, or process disclosed, or represents that its use would not infringe privately owned rights. Reference herein to any specific commercial product, process, or service by trade name, trademark, manufacturer, or otherwise does not necessarily constitute or imply its endorsement, recommendation, or favoring by the United States Government or any agency thereof. The views and opinions of authors expressed herein do not necessarily state or reflect those of the United States Government or any agency thereof. 


\section{DISCLAIMER}

Portions of this document may be illegible in electronic image products. Images are produced from the best available original document. 


\section{A Review of China's Energy Policy}

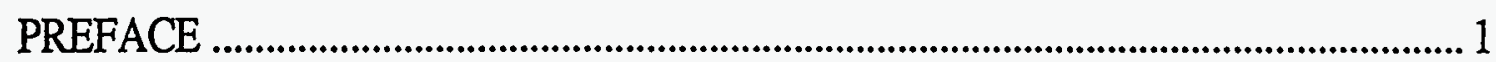

1. ENERGY POLICY UNDER CENTRAL PLANNING, 1952-1979 ...................... 2

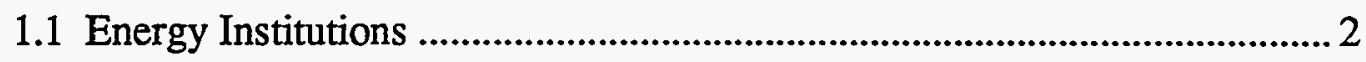

1.2 Energy Development................................................................................... 3

2. ENERGY POLICY DURING THE TRANSITIONAL PERIOD, 1979-Present ...... 6

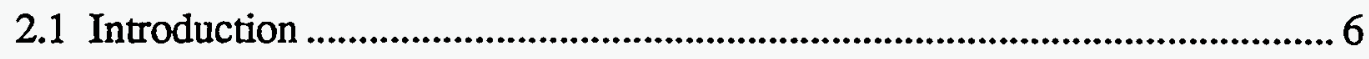

2.2 Changes In Energy Institutions ................................................................ 6

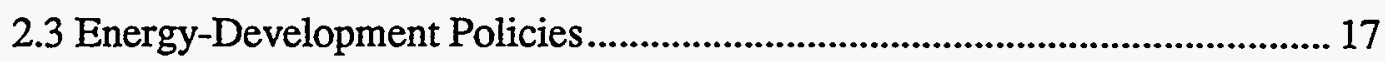

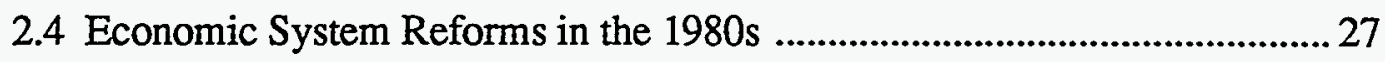

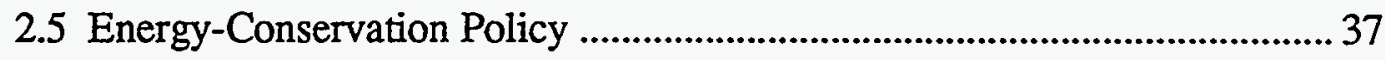

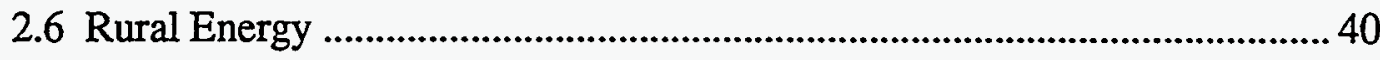

2.7 Evaluation of Policies in the 1980s ........................................................... 43

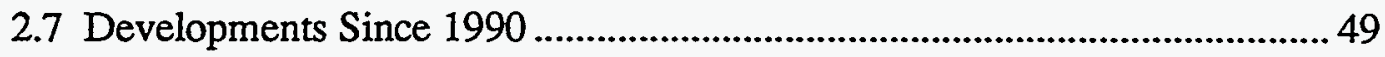

3. THE OUTLOOK FOR CHINA'S ENERGY SYSTEM ….....................................55

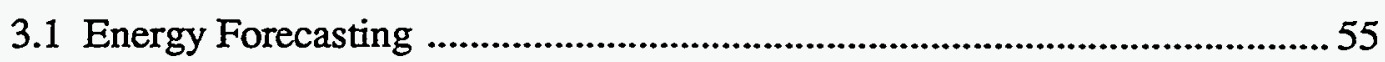

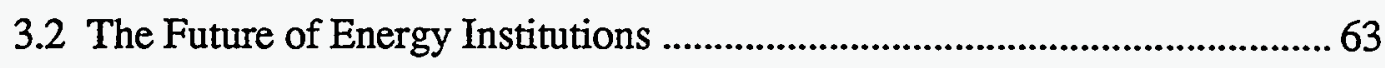

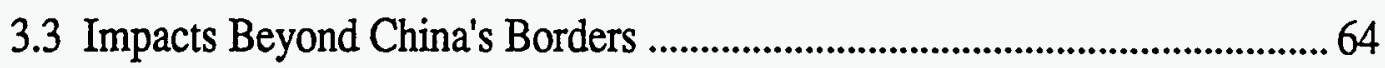

3.4 Prospects for Collaboration between China and the United States ................66

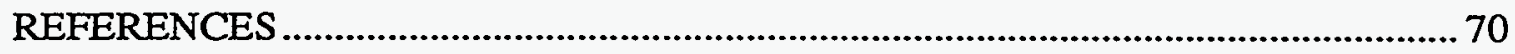

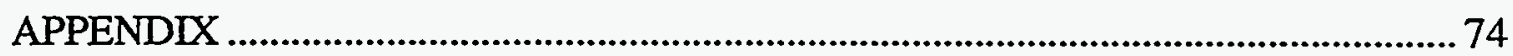




\section{List of Tables}

Table 1-1: Growth Indices for the Economy and Energy Consumption ........................ 4

Table 2-1: Reorganizations in the Energy Sector, 1981-1988 ...................................... 8

Table 2-2: Energy Production Indicators, 1980-1991 …................................................. 20

Table 2-3: Before-Tax Production Costs, Plan Prices,

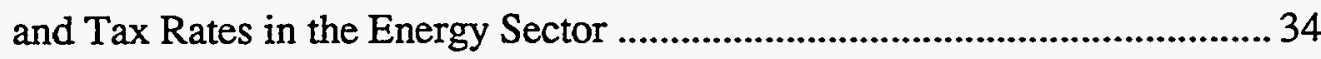

Table 2-5: Energy Consumption Indicators, 1980-1991 .................................................. 38

Table 2-6: Consumption of Primary Commercial Energy per Unit GNP ........................ 39

Table 2-7: Energy Consumption for Ten Energy-Intensive Products:

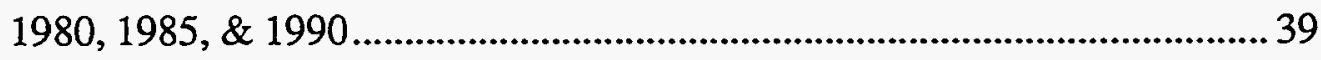

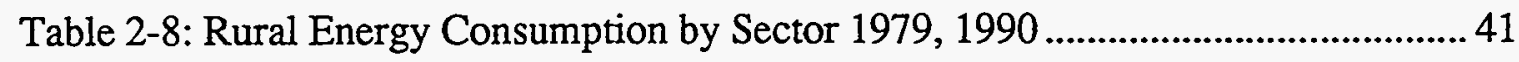

Table 2-9: Indicators of Rural Industrial and Enterprise Growth ................................. 42

Table 2-10: Review of Key Energy Policies, 1979-1993 ................................................ 46

Table 2-11: Oil Imports and Exports, 1990-1992 …….............................................54

Table 3-1: Domestic Energy Demand in the Long-Term Forecast ...................................59

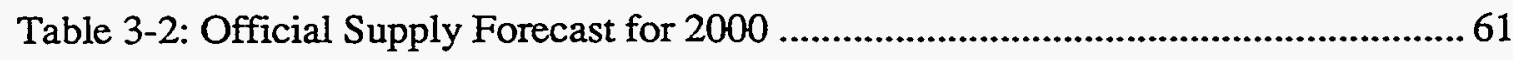

Table 3-3: Domestic Energy Supply Forecasts through 2050 .......................................... 62

Table 3-4: Comparison of Energy Consumption for Chinese and US Products, 1990 ... 67

Table 3-5: Desulfurization in Thermal Power Plants during 1996-2000 .......................... 69

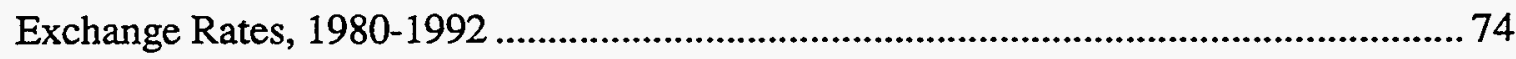

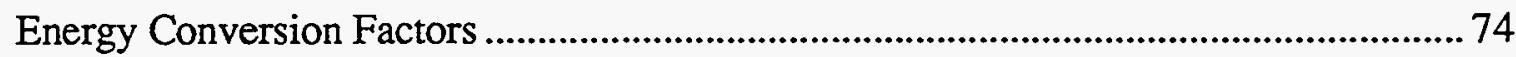

\section{List of Figures}

Figure 2-1: Structure of the Chinese Energy Bureaucracy, 1988 .................................. 9

Figure 2-2: Energy Conservation Institutional Framework (Early 1980s) ...................... 11

Figure 2-3: Shares of Gross Values of Industrial Output by Ownership Types,

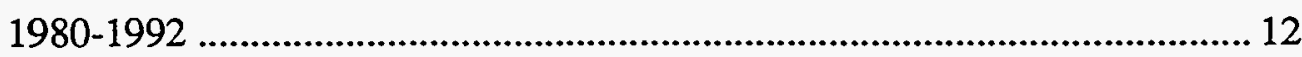

Figure 2-4: Primary Energy Production, 1980-1993 …................................................. 18

Figure 2-5: Electricity Generation, 1980-1993 ….................................................... 19

Figure 2-6: Investment in the Energy Sector, 1981-1990 ............................................... 19

Figure 2-7: Coal Production, 1980-1991 ................................................................... 22

Figure 2-8: Petroleum Production, 1980-1991 ............................................................ 26

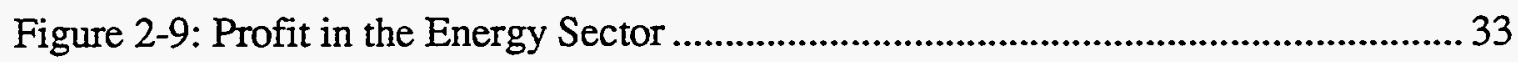

Figure 2-10: Investment in Energy Sector Capital Construction, 1986-1990.................. 35

Figure 3-1: Energy Intensity of GDP and National Income, 1978-1993 ........................ 56 


\section{Acronyms Used in This Paper}

CERS

CNONC

CNOOC

Huaneng

MOE

MWREP

SEIC

SETC

Sinopec

SPC
Chinese Energy Research Society

China National Oil and Natural Gas Corporation

China National Offshore Oil Corporation

Huaneng ("China Energy") Electric Power Development Corporation

Ministry of Energy

Ministry of Water Resources and Electric Power

State Energy Investment Corporation

State Economic and Trade Commission

China National Petrochemical Corporation

State Planning Commission 


\section{PREFACE}

China's rapid economic growth and transition to a market-oriented system in recent years has been hailed as an economic wonder. Real growth rates have soared-GDP grew over 13\% annually in both 1992 and 1993 - and are expected to remain at 8-10\% per year throughout the decade, despite recent attempts to cool China's overheating economy. ${ }^{[1]}$ This tremendous expansion not only will affect China's position in the world economy, but will also exacerbate the country's already serious energy and environmental problems.

Of particular concern from the international perspective has been the rise in greenhouse gas emissions. In 1992 China's primary energy production reached 1075 million tons of coal equivalent ( $\mathrm{Mtce}^{1}$; $31.5 \mathrm{EJ}$ ) - by far the largest in the developing world. ${ }^{2]}$ Because coal is the primary commercial fuel, and will remain so for many years, rapid growth of carbon dioxide emissions is fairly certain. China already ranks second globally in carbon dioxide emissions. Thus the attitude of the Chinese government toward energy and environmental issues becomes increasingly important to those involved in the study and analysis of global climate change and energy issues.

This report is intended to provide a basic understanding of the development of China's energy policymaking over the past four decades. ${ }^{2}$ The paper first reviews institutional development and policymaking under central planning from 1949 to 1979 and then describes at greater length the transition to the current, more market-oriented system. While energy has consistently received a great deal of attention from the central government, the institutional basis for setting and implementing policies has shifted often. Reforms during the past 15 years have been incremental, piecemeal, and occasionally contradictory, but overall have freed a large portion of the energy industry from the strictures of a planned economy and laid the basis for broad price liberalization, progress toward which has accelerated since 1992. Responsibility for energy planning is now dispersed among a number of organizations, rendering coordination of energy development difficult. Likewise, economic reform has rendered obsolete most of the policyimplementation means of the planning era, like massive direct investment. Even so, although the new tools of central control are not fully effective, the trend toward decentralized decisionmaking has been strengthened. The report ends with a summary of energy forecasts used by Chinese policymakers, highlighting current policy goals and the issues that will shape future policy. This report is based on information from Chinese energy experts and research reports and government documents from China.

1 Since coal is China's dominant fuel units of energy are usually expressed in terms of standard coal equivalent. One metric ton of standard coal equivalent (tce) equals $29.31 \mathrm{GJ}, 7.00$ million kcal, or 5.147 barrels of oil equivalent. The average conversion for one ton of Chinese coal is 0.714 tce.

2 For a recent detailed exposition on the topic see Lu Yingzhong, Fueling One Billion: An Insider's Story of Chinese Energy Policy Development, Washington, DC: The Washington Institute, 1993. 


\section{ENERGY POLICY UNDER CENTRAL PLANNING, 1952-1979}

\subsection{Energy Institutions}

When Mao Zedong assumed power in 1949, he made economic growth and rapid industrialization national priorities. His energy policies were directed at securing adequate supplies of primary energy to meet these goals. Between 1952 and 1979, bureaucratic structures and economic systems were often modeled along the lines of the Soviet Union's planned economic system. Within the central government, a web of constantly changing bureaucratic agencies managed the planning, production, and distribution in the energy sector. The State Planning Commission (SPC) included energy production and distribution and investment allocations in its five-year plans. The State Economic Commission coordinated and monitored the implementation of annual and short-term plans. Even the day-to-day energy policies and actual energy production were directed from a ministerial level.

Energy production at the beginning of the 1950s was limited, and one body, the Ministry of Fuels and Power, managed the production of all types of energy. However increasing diversification of supply and the rapid growth of the economy soon overwhelmed the single ministry. In 1955, to respond to the increasing demand for energy services and to impose a more responsive institutional structure, the State Council disbanded the Ministry of Fuels and Power and replaced it with several ministries: the Ministry of Coal Industry (MOC), the Ministry of Petroleum Industry (MOP), and the Ministry of Electric Power Industry (MEP).

During the 1960s the Cultural Revolution reshaped China's institutional structures, with the political turmoil of this decade detouring the country from its earlier developmental path. Since the prevailing ideology favored institutional simplification, in 1970 the central government merged MOC, the Ministry of the Petroleum Industry, and the Ministry of Chemical Industry to form the Ministry of Fuels and Chemical Industries. Similarly, MEC and the Ministry of Water Resources Utilization were combined to form the Ministry of Water Resources and Electric Power. At the same time, the central government transferred the management of all state-run enterprises in the energy sector to local governments.

This dramatic institutional shift contributed to a drop in coal production (China's largest energy source) ${ }^{[3]}$ that limited its ability to sustain adequate energy supplies to support development. The poor performance of the energy sector eventually led to a scaling back of the initial restructuring and by 1975 the central government had resumed control of the larger energy enterprises and reestablished separate ministries for the coal and petroleum industries.

Throughout the central planning period the central Ministries only concentrated on short-term planning for energy production; the well-known five-year plans established by the SPC provided only rough guides of long-term direction. Implementation of the plans relied on administrative 
means for allocation and production decisions, and each year's directions were based on incremental changes from the previous year. Target growth rates for output of industrial subsectors, as well as the selection of projects and allocation of capital, were chosen to serve larger national and social goals. In fact, aside from the 15-Year Electrification Program formulated in the early 1950s, no long-term thorough strategic plan was established for the development of the energy sector.

\subsection{Energy Development}

Although possessing few economic resources, the central government placed a high priority on investment in the energy sector. From the first five-year plan onward, energy-related investments made up nearly one-third of the central government's overall industrial investment ${ }^{[4]}$. China's initial energy production was modest: in 1949 the total output of commercial energy was only 23.7 Mtce. By 1979 however, after two and a half decades of heavy investment, China ranked third in global energy production and consumption, with production totaling some 635 Mtce $^{[3]}$. The annual growth rate for energy production between 1949 and 1979 was nearly 12\%, a rate higher than that of any other country during the same period [3]3

These investments were coupled with a determined effort to promote the development of heavy industry. This promotion ultimately led to industry consuming the lion's share of resources during this period; by 1980 the industrial sector was using about $80 \%$ of the country's primary energy. In the promotion of industrial growth, the central government did not allocate enough energy resources to meet demand in the commercial and residential sectors, which has led to an enormous pent-up demand for energy services in modern China.

As can be seen in Table 1-1, between 1953 and 1979 the growth rate of energy consumption consistently outpaced overall economic growth. During the 26-year period, energy elasticity averaged $1.26^{[3]}$, reflecting a high energy intensity during the period of initial industrialization.

3 In 1979 output of coal, oil, natural gas, and electric power (including both thermal and hydroelectricity) reached $635 \mathrm{Mt}, 106 \mathrm{Mt}, 14.5$ billion cubic meters, and $282 \mathrm{TWh}$. Average annual growth rates between 1952 and 1979 were $10.5 \%, 25.4 \%, 29 \%$ and $12.5 \%$, respectively. 
Table 1-1: Growth Indices for the Economy and Energy Consumption

\begin{tabular}{cccc} 
Year & $\begin{array}{c}\text { Total Output Index (real) } \\
(1953 \text { output }=100)\end{array}$ & $\begin{array}{c}\text { Energy Consumption Index } \\
(1953 \text { consumption = 100) }\end{array}$ & $\begin{array}{c}\text { Index Ratio } \\
\text { (Energy/Output) }\end{array}$ \\
\hline & 100 & 100 & 1.00 \\
1953 & 144.0 & 178.2 & 1.24 \\
1957 & 141.1 & 305.7 & 2.17 \\
1962 & 217.5 & 349.3 & 1.61 \\
1965 & 339.7 & 541.3 & 1.59 \\
1970 & 483.9 & 839.5 & 1.73 \\
1975 & 664.0 & 1082.8 & 1.63 \\
1979 & & & \\
\hline
\end{tabular}

Source: China Statistical Yearbook 1992, China Statistics Press, Beijing, 1992.

\section{Coal Use}

During the central planning period coal became-and to a large degree still is-the mainstay of China's energy supply. Coal is the country's most bountiful fossil energy resource. Easily mined reserves were often located near population centers, thus making its development and use an attractive option. Moreover, until the late 1960s China had few developed oil resources and had to imported oil using hard currency, a drain on state cash reserves. Concern about the cash drain led the central government to set prices for crude oil and oil products higher than international levels to reduce oil demand and to subsidize coal prices to further promote coal use.[5]

The pro-coal policies resulted in some benefits (energy independence, insulation from world oil shocks), but also clearly carried unintended consequences with which Chinese policymakers continue to struggle today. Although the country has since diversified its resource base, the large scale of the supply-and-distribution infrastructure and the ubiquity of coal-using equipment have hindered efforts to establish cleaner commercial energy sources. Today coal accounts for nearly $70 \%$ of primary energy production and consumption, and its share has even increased in recent years. The prolonged use of coal has aggravated urban air pollution, acidified precipitation in southwest China, increased greenhouse gas emissions, spoiled water resources, and overburdened the country's strained transportation infrastructure.

\section{Forces of Change}

Although central planning did allow for a phenomenal growth of the energy supply, nevertheless, the system tended to become inefficient after a certain stage of economic development. Tight controls on the energy sector and rigid institutional structures worked adequately when the size and scope of the economic enterprises were limited and resources could be pooled to meet the immediate demands of local enterprise development. But the growth and diversification of the 
economy over three decades complicated the central planners' attempts to orchestrate a sustained growth. By the mid-1970s, the need to decentralize authority to improve the country's prospects for future growth was becoming clear. Planning efficient production and allocating resources and outputs in an economy as large as China's requires an enormous capacity to gather and process information. Decisions based on incomplete information are necessarily crude and relatively unresponsive to changing circumstances at the local level.

There were other negative effects of China's planning system. Decisionmaking was so concentrated that little opportunity arose for an independent examination of potentially damaging policies (such as the subsidization of coal). Moreover, subjective judgment could significantly effect the course of economic development. Furthermore, lack of competition meant that enterprises had little motivation to improve product quality, develop new processes and products, and reduce costs. Many would have been unprofitable in the absence of state support.

These systemic features contributed to the misallocation of energy resources and hampered China from developing an energy system that could support rapid economic growth. After Mao's death in 1976, a consensus began to emerge among the leadership (especially within reformist circles) that market mechanisms ought to be harnessed to enable economic recovery after a decade of stagnation during the Cultural Revolution. 


\section{ENERGY POLICY DURING THE TRANSITIONAL PERIOD, 1979-Present}

\subsection{Introduction}

Although the Chinese economy developed rapidly between 1959 and 1979, central planning hindered growth and limited the efficient allocation of energy services. The system's inherent inefficiencies-political interference, relative absence of functioning markets, and subjective decisionmaking-all exacerbated China's already pressing energy-supply constraints.

Nineteen seventy-nine was a watershed year. Faced with pressure to improve the economic prospects to retain the government's and the Communist Party's legitimacy, Deng Xiaoping spearheaded a bold economic reform program that was officially sanctioned during the Third Plenum of the Eleventh Party Congress in December of 1978. The principal theme of the Congress was that China could no longer afford to be isolated from the world and that it needed to achieve faster economic development and greater international cooperation to realize its development goals. The goals themselves were ambitious: a fourfold increase in GNP (from 1980 levels) by the year 2000 and another fourfold increase of GNP from 2000 levels in 2050, allowing China to reach living standards of mid-level developed economies like Spain or Greece by the middle of the next century[6].

In this paper we divide the transitional period into two stages. during the first, 1979-1991, constraints on the traditional economic planning system were removed. Since Deng Xiaoping's famous southern tour in the spring of 1992 there has been a more radical and rapid turn toward market mechanisms, including the freeing of many energy prices. Some Chinese economists expect that this second stage will complete its course around 2000 , leaving in its wake average annual real growth rates of $8 \%$ to $10 \%$.

The development of energy policies and energy institutions during this first stage is difficult to characterize simply, since it has exhibited conflicting tendencies and occasional reversals. Nevertheless, throughout the period there has been reasonably consistent movement toward relaxation of centralized control, introduction of market mechanisms in the previously highly controlled energy sector, and even the promotion of international participation in energy development. This chapter first discusses changes in energy institutions and follows with an overview of energy development policies and economic system reforms.

\subsection{Changes In Energy Institutions}

Development and production of energy fall within the domain of energy ministries and corporations. Because of their high levels of consumption, state enterprises also play a key role in the energy institutional structure. Reforms of the economic system have left no sector or 
institution untouched. Responsibility for overall planning has remained the domain of the State Council, the SPC, and more recently the State Economic and Trade Commission (SETC), but ministries have been repeatedly reshuffled; at one time all energy ministries were brought together in one ministry, but have since been disbanded. Along the way, mirroring the trend in other sectors, ministerial authority for energy sector activities has increasingly been spun off to large state-owned corporations that are still closely associated with the government-and indeed retain many of the same personnel-but which have more freedom to allocate investments and manage production. The proliferation of institutions has led to overlaps in areas of authority and made coordination more difficult.

At the beginning of the 1980s the state sector was considered the mainstay of the economy, and the role of the central government was correspondingly large. In 1994 the situation is quite different: the state no longer has the resources to direct the economy through its line ministries and now seeks to influence development through institutions that use different means of control. Institutions currently in place may have more of the gloss than the substance of a market-oriented system, but they do reflect a recognition of the irreversibility of the shrinking state sector. Local institutions have become much larger players in the energy arena and are now capable of undertaking large development projects that were previously the province of the central government.

\section{Planning and Administration}

In the 1980s the organization of the energy sector was fluid, yet the changes tended to reinforce the separation of energy production and distribution from governmental administration. During the decade, two major reorganizations occurred in 1981-1983 and in 1985-1989.

The first reorganization focused on the oil sector. Since the discovery of large oil fields in the late 1960 s, a major concern of the central government was to create the proper institutional structures to stimulate oil production and eliminate direct governmental interference. The Ministry of Petroleum Industry was split into three organizations: the China National Offshore Oil Corporation (CNOOC), Sinopec (or the China National Petroleum Chemical Corporation, CNPCC), and the China National Oil and Natural Gas Corporation (CNONC) (see Table 2-1). CNOOC was organized to direct international cooperation in offshore petroleum development. It held the rights to exploration, development, production, and sale in predetermined offshore zones. Sinopec, run by the State Council, was established to utilize petroleum and natural gas for production of oil products, synthetic materials, and organic raw materials. CNONC focused on domestic exploration and production. This was the first time such a reform had been tried in any of the energy subsectors. 


\section{Table 2-1: Reorganizations in the Energy Sector, 1981-1988}

\begin{tabular}{ll}
\multicolumn{1}{c}{ Date } & \multicolumn{1}{c}{ Reorganization } \\
\hline 1981-1983 & Establishment of the State Energy Commission (disbanded in 1983). \\
January 1981 & Organization of CNOOC \\
February 1982 & $\begin{array}{l}\text { Merging of the Ministry of Electric Power Industry and the Ministry of Water } \\
\text { Resources Utilization into the Ministry of Water Resources and Electric Power }\end{array}$ \\
March 1983 & Establishment of Sinopec \\
July 1983 & $\begin{array}{l}\text { Establishment of the Huaneng Electricity Generation Corporation (in 1988 } \\
\text { renamed the Huaneng Group, Inc.). }\end{array}$ \\
\hline Sep5-1988 & $\begin{array}{l}\text { Establishment of the Ministry of Energy; abolishment of the Ministries of Coal } \\
\text { Industry, Petroleum Industry, Water Resources and Electric Power, and } \\
\text { Nuclear Industry }\end{array}$ \\
June 1988 & $\begin{array}{l}\text { Formation of the National Energy Investment Corporation } \\
\text { July } 1988\end{array}$
\end{tabular}

The second wave of reorganizations, in 1985-1988, was even more dramatic. The reorganization encompassed all energy subsectors and further removed the central government from the details of production. In place of central management, a number of special state-owned companies were formed to improve the performance of the sector. (see the "Energy Corporation" section on page 12 for details). The Ministry of Energy (MOE) was formed as a coordinating body, but its functions were limited to developing energy strategy, planning longterm production, and overseeing major energy-development projects. Even given this mandate, however, the Ministry was in fact active only in the electricity subsector; other subsectors would not coordinate planning and investment activities even though they were nominally under MOE supervision. As a result, once again no single institution was actively coordinating the various subsectors of the energy industry.

Figure 2-1 shows the Chinese government's bureaucratic structure in 1988. The newly created corporations were "supervised" by MOE, but this was only nominally. MOE itself received guidance from the SPC on long-term planning. 


\section{Figure 2-1: Structure of the Chinese Energy Bureaucracy, 1988}

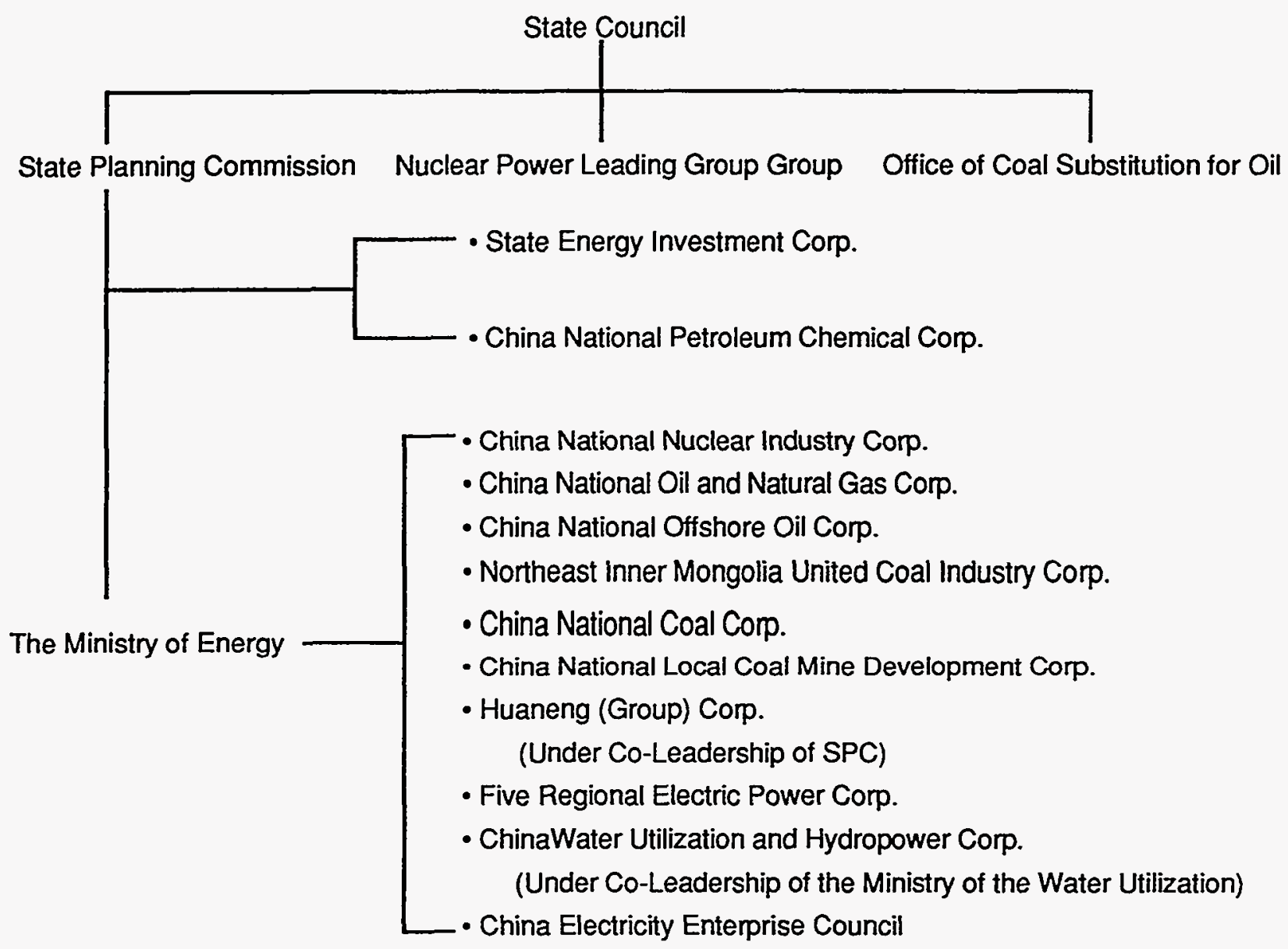

The State Energy Investment Corporation (SEIC), under the leadership of the SPC, was formed in 1988 with responsibility for the central government's energy project investments in the energy sector. ${ }^{4}$ SEIC also has access to foreign capital for joint ventures. For domestic projects SEIC shares responsibility for capital investment with local governments and enterprises. It oversees the bidding and issuance of contracts jointly with the boards of directors of individual projects. SEIC possesses the authority to entrust banks to issue bonds and stocks both domestically and abroad and to fund both enterprises abroad and joint-ventures with foreign companies.

In addition to the diversification of energy-production institutions, this transition period is also responsible for China's successful effort to comprehensively incorporate energy

4 Like other government investment funds, the funds at the SEIC's disposal are divided into two categories: capital construction and technological renovation. The former refers to large projects aimed primarily at creating new production capacity, and the latter to smaller projects intended to improve existing production capacity, but which may also increase production capacity somewhat. 
conservation into the country's institutional structure. 5 (see also the "Energy Conservation" section on page 12) Figure 2-2 identifies the institutional framework for energy-conservation activities in the transition period. The energy-conservation apparatus was developed in parallel at both the central and provincial levels as well as in the planning and production bureaucracies (commissions and line ministries) to improve the effectiveness of policy implementation. At the local level, more than 200 energy-conservation technology centers, with nearly 5000 employees, were set up in ministries and across the country. These centers provide technology consultation, monitoring, and training in energy conservation mainly related to energy use in the industrial sector ${ }^{[7]}$. Enterprises consuming annually $10 \mathrm{ktce}$ or more are required to designate an energy manager and report to the energy-conservation offices in local government branches.

\footnotetext{
5 China's energy conservation programs are credited with saving a total of 280 Mtce between 1981 and 1990. Energy conservation capacity in the end of 1990 reached $55.8 \mathrm{Mtce} / \mathrm{year}$ (compared to energy intensity of production in 1980). For further documentation, please refer to $[7,8]$.
} 


\section{Figure 2-2: Energy Conservation Institutional Framework (Early 1980s)}

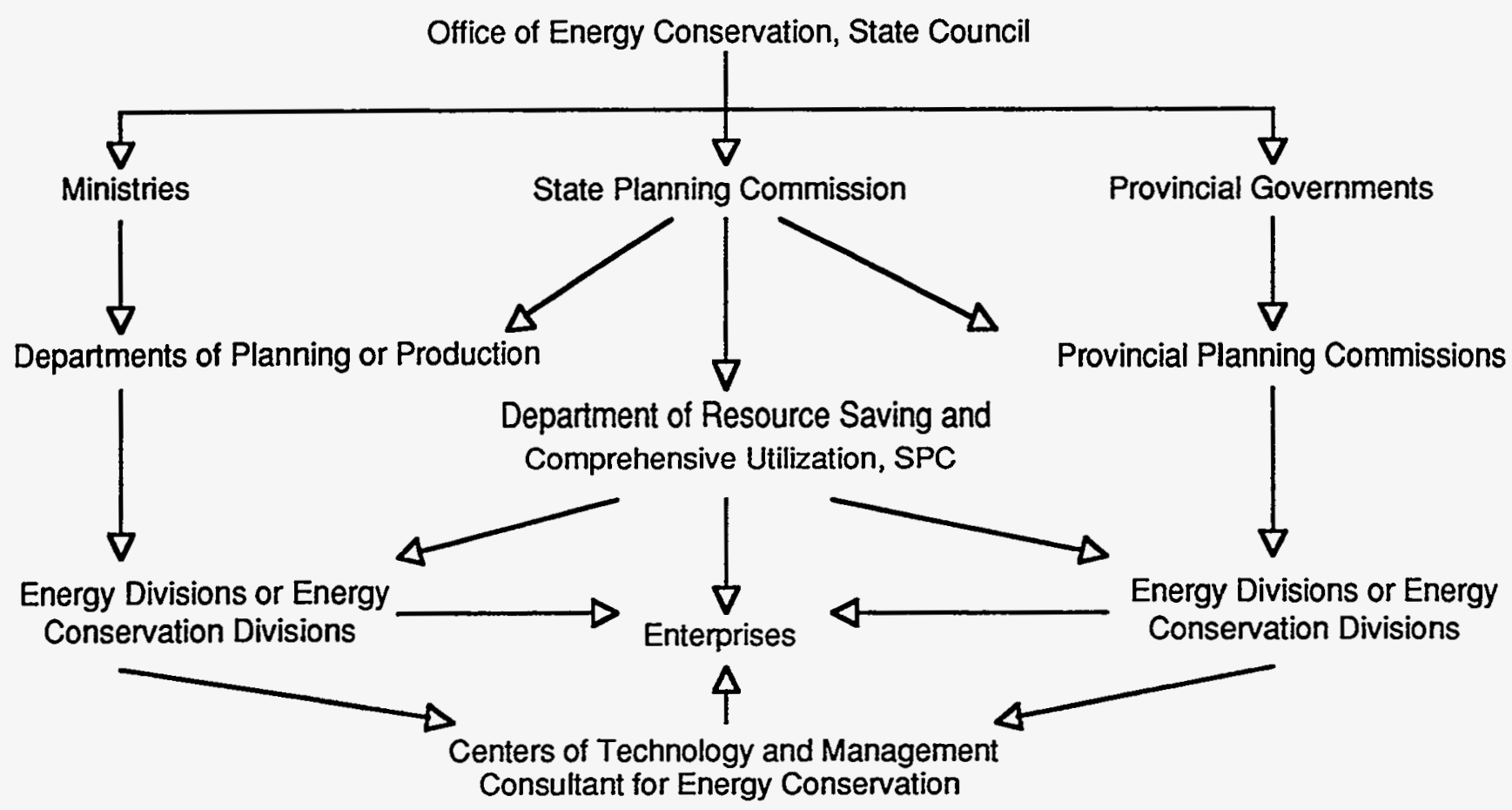

State-Owned Enterprises

Like many other centrally planned economies, China had developed and managed a complex web of state-owned enterprises in the various industrial subsectors. To achieve important goals, such as maintaining full employment and keeping the price of coal-based fertilizers low, the central government subsidized losses in many subsectors and regions. Reductions in central government revenues have made continuation of this practice impossible, and the lack of profitability of many state-owned enterprises is increasingly being recognized as a sensitive but critical hindrance to China's economic reform.

One of the aims of the current reforms has been to grant more independence to state-owned enterprises and separate them from direct government control and assistance. This goal is difficult to accomplish successfully, since enterprises had not been previously subjected to the rigors of markets and are burdened with responsibilities generally not borne by firms in capitalist economies. $^{6}$ Furthermore, the ownership of the enterprises is still unclear. For primarily political reasons, fully privatizing state-owned enterprises is still not possible. Many still require ministry approval for investment plans, product pricing, and marketing and export strategies.

6 State-owned firms are expected to provide workers with housing, schools, medical services, and often additional welfare services such as finding employment for children of workers. In addition, local governments often require enterprises in their jurisdictions to contribute to road building and other infrastructure projects. 
The management structure at some enterprises also remains ambiguous. Although some stateowned energy companies appear to be independent, informal linkages are still critical to effective plant administration and operation and affect decisionmaking in investment allocation, production planning, and even human resource management.

Figure 2-3 highlights the shares (by value) of industrial output by form of enterprise. The share of industrial gross output from state-owned enterprises has declined monotonically since 1980; between 1980 and 1992 real output of state-owned enterprises grew at an annual rate of $8 \%$, while non-state output grew at $23 \%{ }^{[3]}$. The shift toward collective ${ }^{7}$ and private enterprises in the industrial economy is repeated in the coal and electric power industries, but less so in petroleum extraction and refining, which remain dominated by state enterprises.

\section{Figure 2-3: Shares of Gross Values of Industrial Output by Ownership Types 1980-1992}

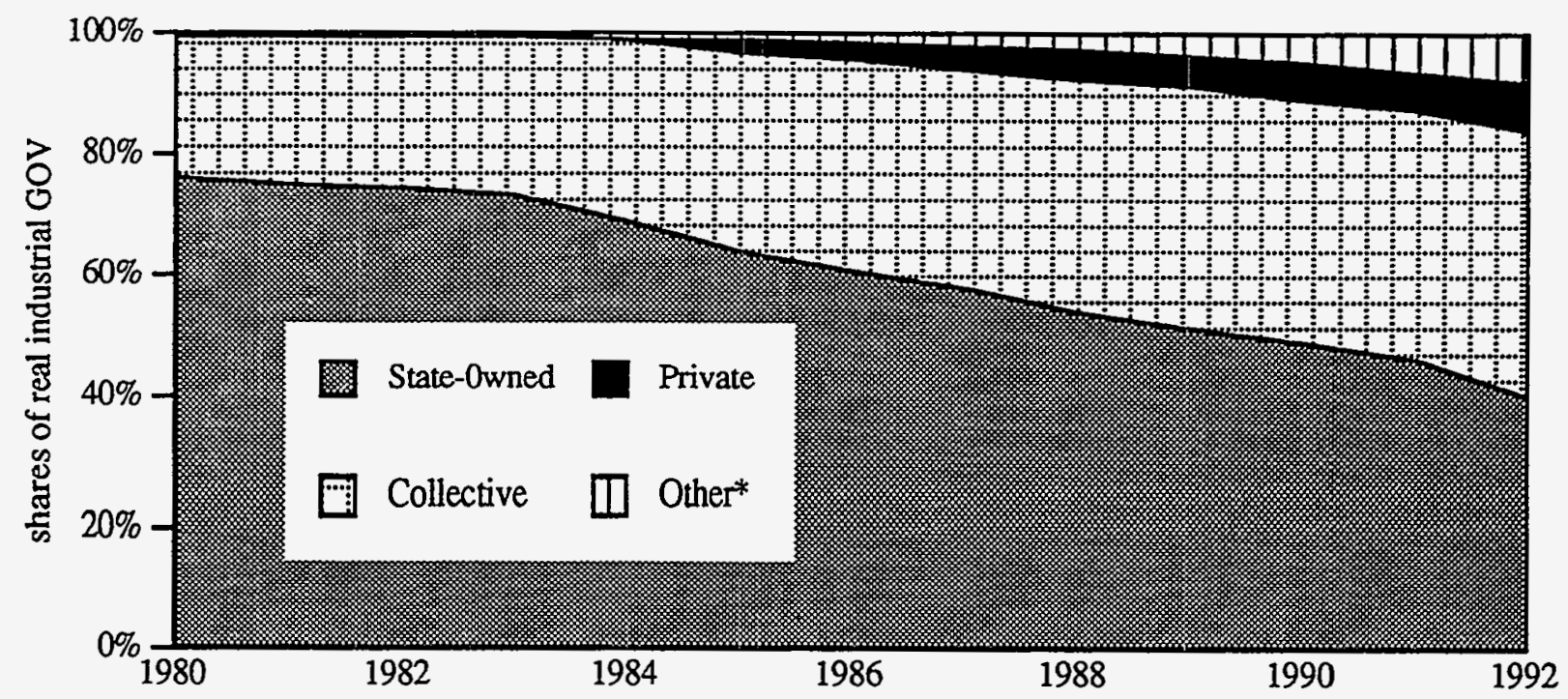

* Primarily joint ventures, both foreign and domestic.

Source: Zhongguo Gongye Jingji Tongji Nianjian (China Industrial Economy Statistical Yearbook), China Statistics Press, Beijing, 1993.

\section{Energy Corporations}

The introduction of energy corporations into China's institutional framework is also characteristic of the transitional period. By the time the Ministry of Energy was established in 1988, the entities responsible for energy production in the coal, oil, and electricity sectors were

7 The category of "collective" ownership should be treated with particular care, since it represents a continuum of ownership types rather than one clearly definable category. In many cases enterprises that are collective in name are effectively controlled by local governments, which may subsidize enterprises in the same way that the central government has done. In other cases, collective enterprises may in fact be privately owned and run, but use the collective label to avoid restrictions on private enterprise activity. 
transformed from direct government administrative entities into state-run, semi-public corporations. The former Ministry of the Coal Industry was divided into the China National Coal Corporation, the Northeast Inner Mongolia United Coal Industry Corporation, and the China National Local Coal Mine Development Corporation. The Ministry of the Petroleum Industry became the CNONC and managed on-shore petroleum development as well as other energy activities. The Huaneng Corporation was created to increase electricity investment and generation. The Ministry of the Nuclear Industry turned its administrative role over to the market-oriented China National Nuclear Industry Corporation.

In exchange for serving as primary production "contractors" for the central government, the energy corporations were given the right to make decisions on production management, personnel changes, and salary and bonus shares for employees. ${ }^{8}$ The aim of the corporations was to increase competition and efficiency in energy production, especially in the utility sector. The Northeast Inner Mongolia United Coal Industry Corporation was committed to developing extensive coal resources in the region as an alternative to depending on coal transportation networks from the Shanxi region.

Like the state-owned enterprises, the energy corporations were by no means fully independent. Much of the capital allocation for the corporations was controlled directly by the central government. For example, the Huaneng Corporation, which was responsible for developing much of China's new thermal generation, was initially financed from a special government coal-for-oil substitution (mei dai you) funds, obtained by diverting oil from domestic consumption to exports. The fund totaled 1.0 to 1.5 billion yuan annually and was generated by artificially maintaining a price differential between the price at which the government bought oil internally and exported it on the world market. ${ }^{[10,11]}$ By 1992, the cumulative fixed capital of Huaneng was more than 35 billion yuan (USD 6.1 billion).

Investment, pricing, and marketing decisions were often influenced by the central government, which has been reluctant to relinquish control over the critical area of energy supply years after many other industrial subsectors have been given relative freedom. Controls on energy prices effectively dictated which energy enterprises and subsectors would make profits and suffer losses; low coal prices, for example, consigned coal mines to a constant struggle to make ends meet. Even detailed construction proposals for some projects had to be approved by the MOE and other government agencies. ${ }^{[12]}$ Corporation management structures were unwieldy and difficult to change.

Factors internal to energy enterprises also presented barriers to more efficient operation. For example, management was very sensitive to worker satisfaction because of its importance to managers' career prospects, not to mention meeting output targets. Managers placed a high

8 The state-run enterprises in the oil, coal, and electricity sectors adopted the contract responsibility system in 1981, 1985 , and 1988, respectively. 
priority on increasing workers' wages through bonuses and on improving their livelihood through such means as improving housing. This made cost control very difficult, diverted funds that might have been used for investment, and contributed to an overall inflationary environment.

The country's energy industries, which are now being forced to improve production efficiency, continue to struggle with the consequences of belated reform. The government cannot afford adequate social insurance or retraining costs for laid-off workers. Some estimates place the cost of re-employment of a coal miner at 150,000 yuan (USD 26,0009 ). [13,14] Since nearly two-thirds of the labor force in the state-owned coal mines is redundant, the resources for retraining have been overwhelmed by the sheer number of retrainees. Some state-owned coal enterprises now face increasing unrest from unemployed workers.

In overall performance the coal corporations have definitely been the weakest. State-owned coal mines were not able to pay back 44.5 billion yuan (USD 8.36 billion) of loans for coal mine construction in 1991. Moreover, they had no way of raising the 5.6 billion yuan (USD 1.1 billion ${ }^{10}$ ) needed to recover land lost to subsidence (sinking of the earth due to underground coal mining) and the 4.0 billion yuan needed for safety equipment and production maintenance. [15] The central government faced increasingly heavy burdens in propping up failing enterprises. Subsidies totaling 7.73 billion yuan (USD 2.05 billion) were granted to state-owned energy enterprises in 1989 , accounting for $81 \%$ of total subsidies to industry. ${ }^{[4]}$

\section{Decentralization}

The historical relationship between the central government and local administrations has been characterized by a lack of cooperation and divergent development objectives. Under the central planning system, local administrations had little room to take initiative for development projects, and projects often did not fit in well with local needs and conditions, contributing to an antipathy between the central and local levels. Since the country's territory is so vast, local interests so strong, and ethnic issues so problematic in some areas (especially in the far west), coordinating policies from Beijing can be problematic. In recognition of these difficulties, one element of the economic reform program was to improve central-local government relationships. This plan was called "sharing power and benefits."

After 1987, local administrations gained more power over financial decisions and project selection and could ratify energy sector projects costing up to 50 million yuan. (The previous level had been 10 million yuan.) Local governments were also allowed to examine and approve fuel-fired power plants with capacities of up to $800 \mathrm{MW}$ and hydropower stations with capacities of up to $100 \mathrm{MW}$. The contribution by local governments to total investment in power plants 
increased from $1 \%$ in 1983 to $17 \%$ in 1990 , or from about 57 million yuan to 4.59 billion yuan. The revenue from a special tax on power development imposed in 1988 was earmarked for local power construction. The central government encouraged local administrations to cooperate in the development of energy projects in other ways as well, such as providing rights-of-way for long-distance power transmission lines ${ }^{[16]}$.

Before the reforms, local administrations were required to transfer a major part of their revenues to the central government. In 1980 a new treasury reform policy required local administrations to establish quota contracts with the central government. Under these contracts, local administrations were only obligated to pass on to the central government a fixed amount of the revenue they collected and could allocate the rest themselves. This trend continued, and in 1985 tax laws allotted local governments additional powers over their funds ${ }^{[15]}$. As a result of these policies, local administrations shared more financial power and were able to invest more in local projects.

In the special economic zones-Shenzhen, Zhuhai, and Shantou in Guangdong Province, Xiamen in Fujian Province, and Hainan Province-the local administrations became more independent than elsewhere. The market-oriented energy systems in these economic zones were well developed and have attracted more foreign investment in energy development than other areas. In 1991, Guandong and Fujian provinces received a total of $\$ 2.4$ billion of foreign investment, accounting for $42 \%$ and $10 \%$,respectively, of total investment in each province ${ }^{[4]}$.

In theory, the delegation of authority for energy investment to local administrations was a logical step; the reality was much less satisfactory for the central authorities. The increased revenue did make local administrations and enterprises stronger investors, but they did not spend much of the money investing in energy projects. Instead, a major portion of the new revenues were invested in light industry, processing industries, real estate, and small power plants (10 MW was a popular size), all of which yielded higher profits in the short term because they tended to be less capital-intensive. Energy projects tend to be long-term ventures requiring long construction periods and offering lower rates of return than these other investments. Therefore, local administrations and enterprises invested only small amounts of capital in energy sectors and tended to rely on the central government to provide financial credit and assistance to help meet energy supply shortfalls.

Because local administrations tend to take any opportunity to assert control over their territory (as has been the case historically in China), they often took steps to prevent imports of commodities from other regions and to duplicate production capacity already found in other regions. This tendency was encouraged while Mao Zedong was in power through policies, in part motivated by strategic reasoning, stressing the need for localities to become self-sufficient. This unnecessary duplication of investment resulted in the development of small energyintensive manufacturing plants that consumed more energy than larger plants for the same 
processes. Local administrations also imposed many energy taxes and fees on industrial customers and forced centrally-owned enterprises to pay higher rents for land, pollution fees, and other service fees.

The relationship between central government and local administrations is complicated and requires careful coordination. On the one hand, it appears that a reliance on central government planning dampens economic activity. On the other hand, local administrations respond to local concerns that are often at odds with national energy investment needs. In recent years, the central government's financial deficit has increased continuously while local administrations have become financially better off through increased tax revenues, weakening the central government's ability to control the pace and geographic distribution of development. Central planners find themselves in a dilemma, desiring at once to encourage rapid development (which has occurred almost entirely in the coastal provinces) and to ensure that such development is rational and does not result in large inequities in the distribution of wealth. Regional economic disparities have increased, and social instability resulting partially therefrom has become a recognized issue.

\section{Nongovernmental Organizations}

Nongovernmental organizations (NGOs) have been conspicuously absent in most areas of Chinese policymaking. Research organizations have been attached to the various commissions and ministries of course, and academic institutions have had some input into the workings of the government, but NGOs in the forms found in Western countries are a rarity. In the energy arena, however, there is a major exception: the China Energy Research Society (CERS). While it cannot be considered a grassroots organization, since its founding it has been a credibly independent voice in the arena of energy policy.

Concerned with China's critical energy situation - the problems of meeting the energy demands of economic development and the prevention of environmental degradation - a group of energy experts formed CERS in January 1981. Its members came from various universities, research institutes, consultant firms, state energy corporations, other enterprises, and government agencies. Consequently, it was able to open lines of communication across institutional boundaries that would otherwise have been difficult to bridge. Many members brought with them powerful connections to decisionmakers within the government. Since its founding, CERS has been committed to creating an academic free speech atmosphere for the free exchange of ideas and to providing support for governmental policies and decisions in energy and other related areas. CERS has been influential in charting the course from the central planning of the energy system to one that relies much more heavily on markets and relatively more independent corporations. Its members were among the first to recognize the inadequacy of energy supply to 
meet development targets, and they were critical to the establishment of the central government's program of energy-conservation investments. Currently CERS has 27 provincial branches and more than 1400 members, giving it wide geographical and sectoral coverage. Eight committees have been established: Energy System Engineering, Energy Economics, Rural Energy, Urban Energy, Geothermal Energy, New and Renewable Energy, Energy Conservation and Enterprise Energy Management, and Energy and Environment.

CERS functions as a consulting body for energy planning and the development of energy policies, regulations, rules, and programs at national, regional, and sectoral levels. Virtually every important energy-related decision made since 1981 has involved CERS members, including areas such as choice of energy supply technologies, forecasting and planning for China's energy system in 2000 , energy-conservation policy, rural energy development strategies, economic reforms in energy sectors, energy resource development, and the Three Gorges hydropower project. Besides advocating various positions, CERS also organizes its members to carry out feasibility studies, project evaluations, and policy analyses for clients. It holds seminars, workshops, and conferences on both domestic and international issues and publishes papers (more than 2500 to date), proceedings, and two journals, World Energy Guide and Energy Policy Research Communiqué, which are circulated only within China. To promote public awareness and knowledge about energy issues and environmental protection, CERS uses the media to disseminate information, promotes adoption of energy conservation technologies, and has trained more than 2000 energy managers.

\subsection{Energy-Development Policies}

Energy development policies in the early 1980s were concentrated responses to the failure of oil output to match earlier predictions and the consequent inadequacy of the energy supply to support ambitious economic development goals. On the demand side this response took the form of an emphasis on energy conservation, funded on a scale unprecedented in any other country (see Section 2.5), and an effort to switch oil-using facilities to coal. Since ailing state-owned coal mines would not be able to invest enough to provide for the anticipated growth in demand, small collective and private mines were allowed to develop, which they did beyond all expectations. By the middle of the decade, electric power had become the focus of most of the government's development efforts, and even today electric power, including nuclear power, accounts for the largest share of government investment in the energy sector. Price reforms and new funding mechanisms were introduced to attract investment from other sources. Petroleum and natural gas were relatively neglected. With little exploration activity, efforts centered on maintaining output from existing fields.

Figures 2-4 and 2-5 reveal that the scale of energy development under these policies was 
quite rapid. Growth in primary energy production was achieved through expanding coal supply. Electricity generation doubled in a decade, primarily by burning much of the increment in coal production in new power plants. Figure 2-6, displaying investment in energy sectors, shows the primacy given to electricity development. Petroleum and natural gas investment rose, but by a lesser amount, and the coal industry relied on development of low-cost, labor-intensive rural mines.

Figure 2-4: Primary Energy Production, 1980-1993

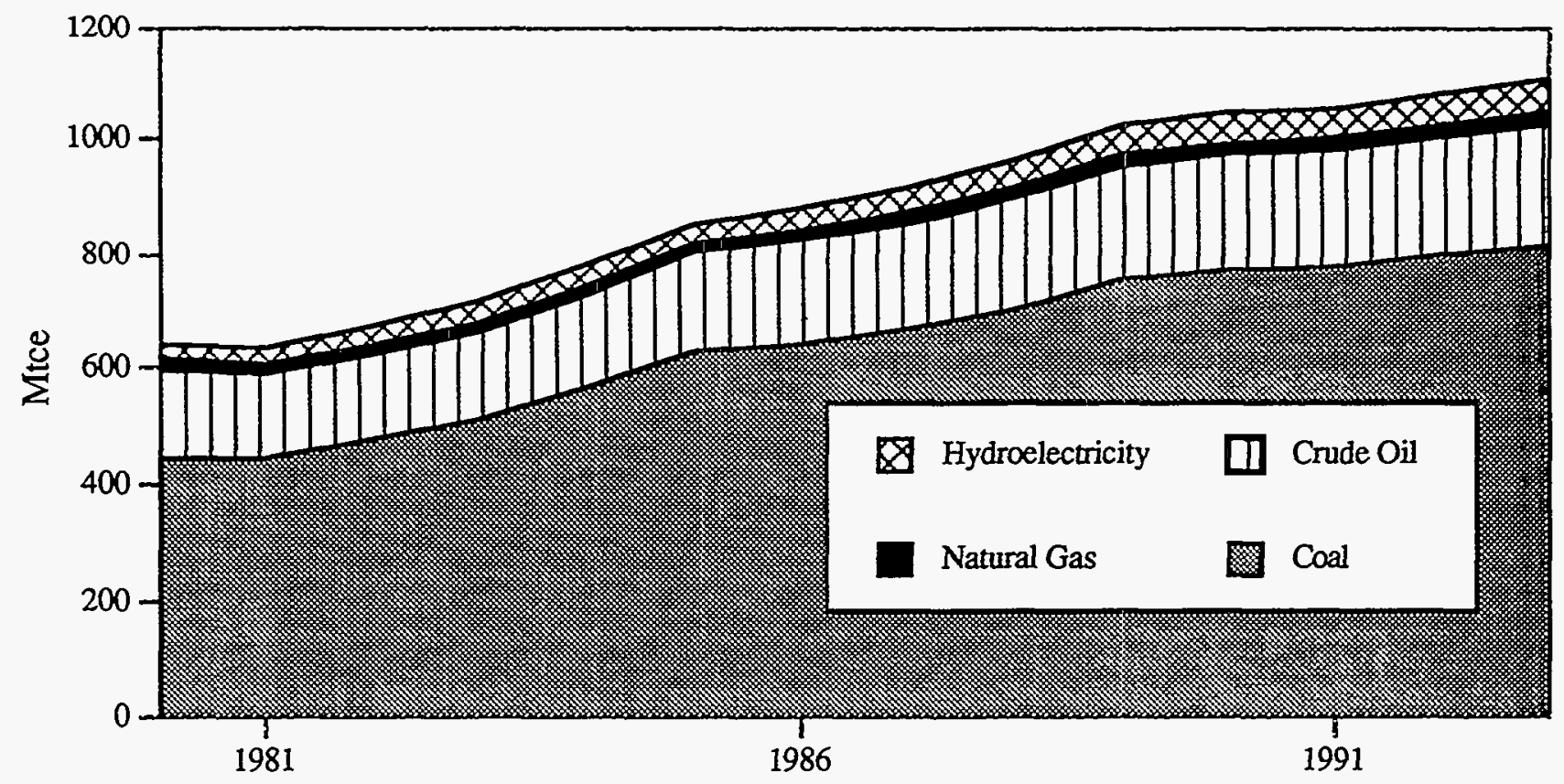

Source: Zhongguo Tongji Zhaiyao (Statistical Survey of China), China Statistics Press, 1994. 
Figure 2-5: Electricity Generation, 1980-1993

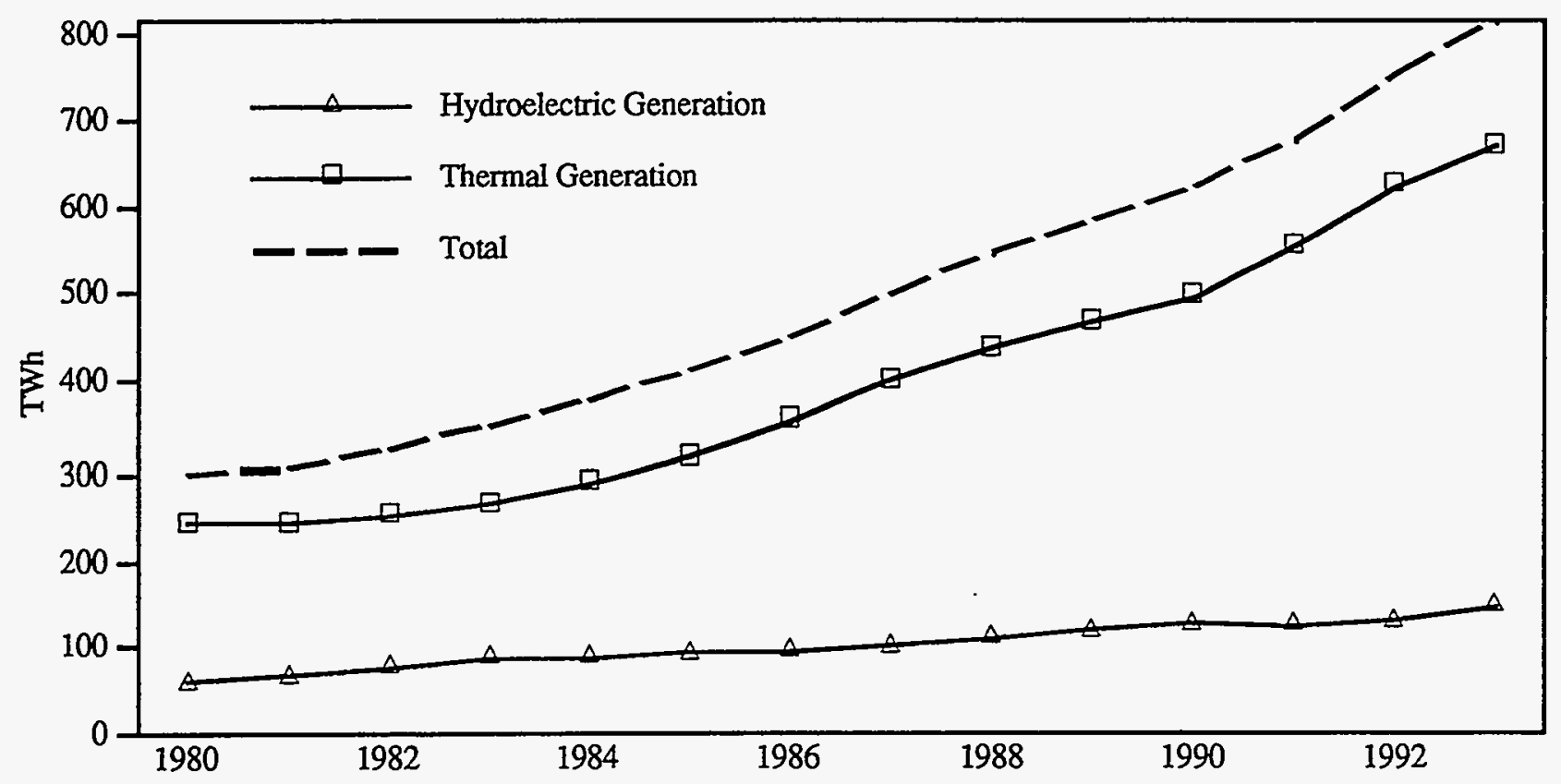

Source: Zhongguo Tongji Zhaiyao (Statistical Survey of China), China Statistics Press, 1994.

Figure 2-6: Investment in the Energy Sector, 1981-1990

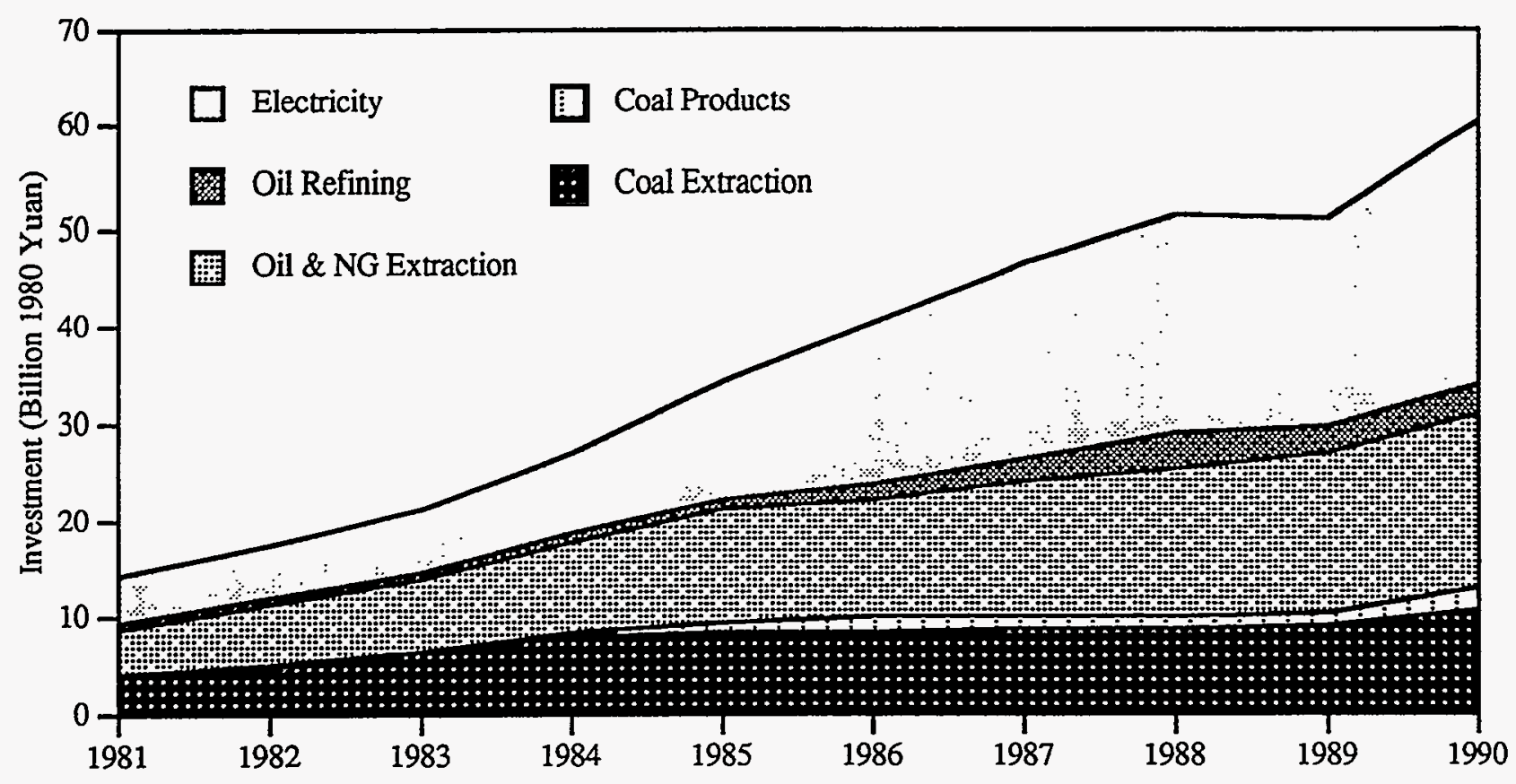

Source: [4] 
Targets for Socioeconomic Development

In 1980, as part of its long-term economic development plan, the central government established a long-term economic goal to double GNP per capita for 1990 to $\$ 500$ and to raise it to $\$ 1000$ by the year 2000, and a further $\$ 4000$ by the year 2050 (in 1980 US constant dollars) ${ }^{[6]}$. Although viewed as very ambitious, the 1990 target was realized; GNP per capita (925 yuan) was double of 1980 levels (465 yuan/capita) [4]. To place the central government's efforts at market reform and energy development in a better context, we present a brief overview of the subsectoral trends in energy development policy.

China's ambitious development targets required enormous growth from the energy sector, which became a priority investment area for the government. From 1979-1991, primary energy output increased more than $62 \%$, from 646 Mtce to 1048 Mtce. Electricity generation grew from $282 \mathrm{TWh}$ to $678 \mathrm{TWh}$, increasing $140 \%$. Table 2-2 shows that the average annual growth rate of GNP from 1980 to 1991 was $8.8 \%$, while the elasticities for total energy production and power generation were 0.46 and 0.95 , respectively.

Table 2-2: Energy Production Indicators, 1980-1991

\begin{tabular}{|c|c|c|c|c|c|}
\hline & \multicolumn{3}{|c|}{ Annual Growth } & \multicolumn{2}{|c|}{ Elasticities } \\
\hline & GNP & $\begin{array}{c}\text { Energy } \\
\text { Production }\end{array}$ & $\begin{array}{l}\text { Electricity } \\
\text { Generation }\end{array}$ & $\begin{array}{c}\text { Total } \\
\text { Energy } \\
\end{array}$ & Electricity \\
\hline 1980 & $7.9 \%$ & $-1.3 \%$ & $6.6 \%$ & -0.16 & 0.82 \\
\hline 1981 & $4.4 \%$ & $-0.8 \%$ & $2.9 \%$ & -0.18 & 0.66 \\
\hline 1982 & $8.8 \%$ & $5.6 \%$ & $6.0 \%$ & 0.64 & 0.68 \\
\hline 1983 & $10.4 \%$ & $6.7 \%$ & $7.3 \%$ & 0.64 & 0.70 \\
\hline 1984 & $14.7 \%$ & $9.2 \%$ & $7.3 \%$ & 0.63 & 0.50 \\
\hline 1985 & $12.8 \%$ & $9.9 \%$ & $8.9 \%$ & 0.77 & 0.70 \\
\hline 1986 & $8.1 \%$ & $3.0 \%$ & $9.5 \%$ & 0.37 & 1.17 \\
\hline 1987 & $10.9 \%$ & $3.6 \%$ & $10.6 \%$ & 0.33 & 0.97 \\
\hline 1988 & $11.3 \%$ & $5.0 \%$ & $9.6 \%$ & 0.44 & 0.85 \\
\hline 1989 & $4.4 \%$ & $6.1 \%$ & $7.3 \%$ & 1.39 & 1.66 \\
\hline 1990 & $4.1 \%$ & $2.2 \%$ & $6.2 \%$ & 0.54 & 1.51 \\
\hline 1991 & $7.7 \%$ & $0.9 \%$ & $9.1 \%$ & 0.12 & 1.18 \\
\hline $\begin{array}{l}\text { Ann. Avg. } \\
\text { 1980-1991 }\end{array}$ & $8.8 \%$ & $4.2 \%$ & $7.6 \%$ & 0.46 & 0.95 \\
\hline
\end{tabular}

Source: China Statistical Yearbook 1992, China Statistics Press, Beijing, 1992.

These elasticities are relatively low for a country at China's stage of development, but they probably reflect the effect of energy shortages as much as structural change in the economy or intentional conservation. ${ }^{11}$ The high economic growth in the 1980 s exerted tremendous

11 Problems with statistical indicators, e.g., a degree of hidden inflation in the real output figures, may also be in 
pressures on the energy supply. The central government could not employ either the previous command-and-control methods or pure market tools to make effective macroeconomic adjustments in supply. In mid-1988, China was faced with a serious energy-supply crisis. Estimates indicated that nearly $40 \%$ of the total industrial capacity was idle across the country and that one-third of the electricity needed for agricultural production was not available because of a lack of energy supplies. The crisis resulted in a 400 billion yuan loss in GNP, and a 50 billion yuan loss in government revenues ${ }^{[17]}$. The poor state of China's transportation infrastructure was partly to blame; even in 1990, two years after the worst period of supply problems, about $100 \mathrm{Mt}$ of coal was stockpiled around the country, tying up 2 billion yuan of working capital $[17] .12$

\section{Coal Development}

China's richest high-quality coal resources (primarily bituminous coal) are in eastern and northern regions. Most investment in large mines has been directed to these areas (Shanxi, Shaanxi, Inner Mongolia, Shandong, and Heilongjiang Provinces), but a significant amount has gone to the southwest (Guizhou and Sichuan Provinces).

Even before the 1980s the government realized that state-owned mines would not be capable of meeting the growing demand caused by economic expansion. The government explored alternative approaches to stimulating coal production., beginning, in the late 1970 s, with the formation of collective and private coal mines in rural areas. The results were astounding. From 1980 to 1990 , the output of collective and private mines increased from $113.6 \mathrm{Mt}$ to $389.7 \mathrm{Mt}$ (the increase for private mines alone was $43.3 \mathrm{Mt}$ ), rising from $18 \%$ of total production in 1980 to $36 \%$ in 1990 . Sixty percent of the total national increase in coal production in the last decade came from these small coal mines ${ }^{[18]}$ (see Figure 2-7).

part responsible.

12 Compared with the $12.8 \%$ growth rate in GNP and $20.8 \%$ growth rate in industry in 1992, the growth rate in transportation capacity was much lower, only $3.8 \%$ [2]. Consequently, at least $30 \%$ of the freight in 1993 was not able to be shipped ${ }^{[18]}$. 
Figure 2-7: Coal Production, 1980-1991

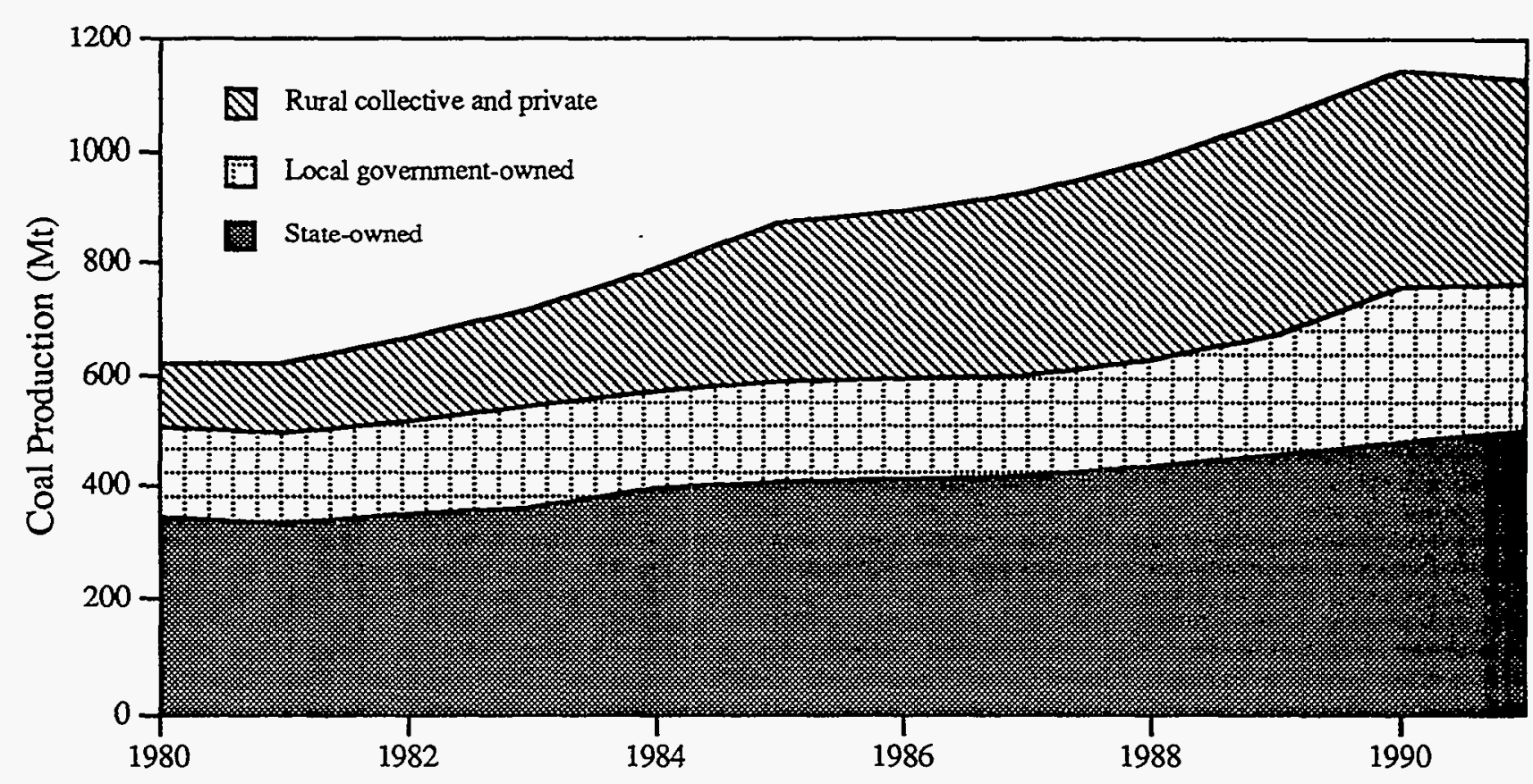

Source: [4].

Part of the expansion of output from state-owned mines was brought about by changes in the production control and pricing systems. Production and distribution of coal had been governed by a quota system, in which the central government fixed output and prices for each state-owned enterprise. There were three types of prices for coal: plan prices, indicative prices, and negotiated prices. The plan prices were the lowest, most heavily subsidized prices. Indicative prices were based on plan prices, with adjustments added, but were still lower than negotiated prices, which were effectively floating market prices. State-owned enterprises were required to sell $81 \%$ of their output at plan prices, $14 \%$ at indicative prices, and the remaining $5 \%$ for whatever they could negotiate.

Beginning in 1984, the government allowed limited free markets for coal to develop and permitted state-owned mines to sell $5 \%$ of their output at negotiated, or market prices. Following the precedent set with the oil industry, the State Council in 1985 made a five-year contract with the Ministry of the Coal Industry to guarantee output from state-owned mines in return for more freedom in managing mine operations. Output from state-owned mines did rise, but the real source of expanded coal production was the non-state sector, composed of small private and collective coal mines which, beginning in 1984, were not subject to quotas and able to sell coal at high market rates. ${ }^{13}$ The combination of policies had a strong effect on increasing the amount of

13 One consequence was that the generally higher quality coal from state-owned mines was much cheaper than the lower quality product from rural mines. 
coal produced and sold at free market rates. In 1990, $26 \%$ of coal output was sold on the free market. Of this amount nearly $90 \%$ came from rural coal mines ${ }^{[15]}$. The share of production capacity from state-owned mines continued to decrease and by 1990 fell to one-fourth of total capacity.

During the 1980s, economic reforms in the energy sector lagged behind those in other sectors. Poor profitability of state-owned mines limited their ability to purchase ever more expensive, new mining equipment, threatening many mines with bankruptcy. During the same periods, state investment allocations failed to meet plan targets. The five-year contract, while improving flexibility, also led state-owned enterprises to focus on short-term benefits, leading many mines to cut short the extraction from difficult seams, decrease their rate of coal recovery, and waste large amounts of coal resources ${ }^{[20]}$.

During this period the central government also began to look more carefully at ways to improve the efficiency of coal utilization. For example, the government promoted utilization of more efficient anthracite in urban households and planned for the development of bituminous coal and coking coal resources for power generation. There were efforts to improve coal resource-utilization efficiency by limiting the operation of unlicensed small coal mines that encroached on state-owned coal fields. It also became standard policy to encourage coal (and coal equipment) exports and to import advanced technology related to coal development, when feasible.

In 1982, the State Council issued plans to concentrate on building a coal base centered in Shanxi province, but also including areas in western Inner Mongolia, northern Shaanxi Province, the Ningxia Hui Autonomous Region, and western Henan Province. The plans called for development of minemouth power plants, dedicated railways for coal, and energy-intensive industries (e.g., chemical fertilizers, aluminum, and steel) in the name of building up the regional economy and alleviating national energy shortages. The policy has been considered a success by many. Coal output in Shanxi Province rose from $121 \mathrm{Mt}$ in 1980 to $286 \mathrm{Mt}$ in 1990, accounting for nearly $27 \%$ of national output in the latter year. During the same period, the net amount of coal exported from the region increased from $61 \mathrm{Mt}$ to $146 \mathrm{Mt}$, or about $58 \%$ of coal shipments. Electricity generation grew from $12 \mathrm{TWh}$ to over $31 \mathrm{TWh}$, and in $19906.5 \mathrm{TWh}$ was wheeled to other regions-the equivalent of 3.5 million tons of coal[21].

\section{Electric Power Development}

China's long-term plans call for the installation of about $310 \mathrm{GW}$ of capacity by the year $2000^{[22]}$. For most of the transition period, China's growth in capacity and generation has been substantial. Electricity generation between 1979-1992 nearly tripled from 282 TWh to 747 TWh ${ }^{[17]}$, while capacity grew from $63 \mathrm{GW}$ to $167 \mathrm{GW}$. In order to stimulate investments in new 
capacity, the central government increasingly relied on market-based instruments and incentives for the power sector. In 1987, for example, the government began issuing bonds for state-owned utility construction and stocks for utilities to increase access to capital. The investment bonds soon became too expensive for state-owned utilities, however, bond prices in 1989 were $29.5 \%$ higher than in 1987. Three billion yuan in bonds were issued in 1987, but only 0.5 billion yuan in 1990[16]. Many local utilities, which were financed by local taxes or collective funds, set higher electricity prices based on the cost of construction of the plant plus a reasonable rate of return.

Other reforms intended to stimulate investment included special taxes and changes in pricing regulations. At the beginning of 1988 a tax of 0.02 yuan $/ \mathrm{kWh}$ was imposed on industrial and commercial consumers for the construction of large and medium power stations. Another step to increase the development of power was the reduction of quotas for electricity to be sold at plan prices. In 1990 state run-power stations were allowed to sell $10 \%$ of their output at higher indicative prices, instead of having to sell their entire output at plan prices ${ }^{[16]}$. This was the first step in releasing the rigid controls on electricity prices.

In order to balance the competing development interests, China adopted a policy called "walking on two legs," referring to the simultaneous development of both hydropower stations and thermal power plants. Recent electricity development has favored thermal-based systems since they require much less lead time and less capital investment. Hydropower development was emphasized in the upper and middle streams of the Yellow River, the upper and middle mainstreams and tributaries of the Yangtze River, and the Hongshui River. Medium and small hydropower stations and pumped storage power stations were built in coastal regions where electricity shortages were especially severe.

In some areas (especially in the North) the scarcity of water resources has limited development of coal-fired plants. When possible, large coal-fired power plants were constructed at ports along the east coast where there is convenient access to cooling water supplies and where coal transportation costs are relatively low. Other approaches include heavy investment in dedicated railway lines to transport coal to demand centers, which generally have more water. Most recently, the central government has agreed to allow $100 \%$ foreign ownership of new generation facilities in order to ensure adequate installation of new capacity[23].

Another major policy concern has been the attempt to improve the average efficiency of thermal power plants. Economic forces (e.g., lower first costs) tend to push regional utilities and industrial enterprises to build smaller plants, which run at much lower efficiencies and also run counter to China's long-term conservation goals. As a general policy, the central government has encouraged the construction of large fuel-fired power plants (greater than $300 \mathrm{MW}$ ) and the use of cogeneration in urban areas and industrial zones, and limited the development of less efficient condensing power plants with capacities under $25 \mathrm{MW}{ }^{[24]}$. Transmission networks have 
continued to expand rapidly, and there have been several upgrades to higher voltage systems during this transition period. Inefficiencies still exist, especially in rural grids, where line-loss rates of well over $25 \%$ are common. Transmission losses are high even in the larger, more efficient grids, and a solution of this problem appears still far off.

\section{Nuclear Power Development}

Government policymakers view the development of nuclear generation capacity in China as an integral aspect of meeting future energy demand in resource-poor, high-demand coastal areas. As a result, both a detailed technological policy and a schedule for nuclear power development have been in place for years. The policy emphasizes the construction of a $600 \mathrm{MW}$ capacity light-water reactor, research and development for advanced light-water reactors, and the construction of several more light-water reactors during the next few decades to reach a capacity of at least $2 \mathrm{GW}$ by 2020[26].14 Chinese specialists have also been interested in advanced nuclear-fuel cycle technologies. Development of capacity has been slower than initially planned however. Technological difficulties and construction lags slowed the startup of China's first reactors, but the domestically designed $300 \mathrm{MW}$ reactor at Qinshan (in Zhejiang near Shanghai).and two $900 \mathrm{MW}$ units built with French assistance at Daya Bay (in Guangdong near Hong Kong) are currently operational. Provinces that have nuclear power plants in the planning stages include Liaoning, Jiangxi, Fujian, and Guangdong.

\section{Petroleum Development}

Several oil discoveries in the late 1960s, the largest of which was the Daqing field in Heilongjiang province, boosted oil production (see Figure 2-8). Since oil export revenues have been a boon for the overall economy, China's approach has been to maximize production levels in existing fields and continue exploration and development in new fields. Oil exploration activities were carried out in the areas of Xinjiang, the Bohai Sea, and the East and South China Seas, as well as the development of the Tarim basin in Xinjiang.

\footnotetext{
14 Many people inside China view this as an overly optimistic goal. The expense of nuclear power, in this view, is likely to restrict its development to a few plants serving the wealthiest coastal areas.
} 


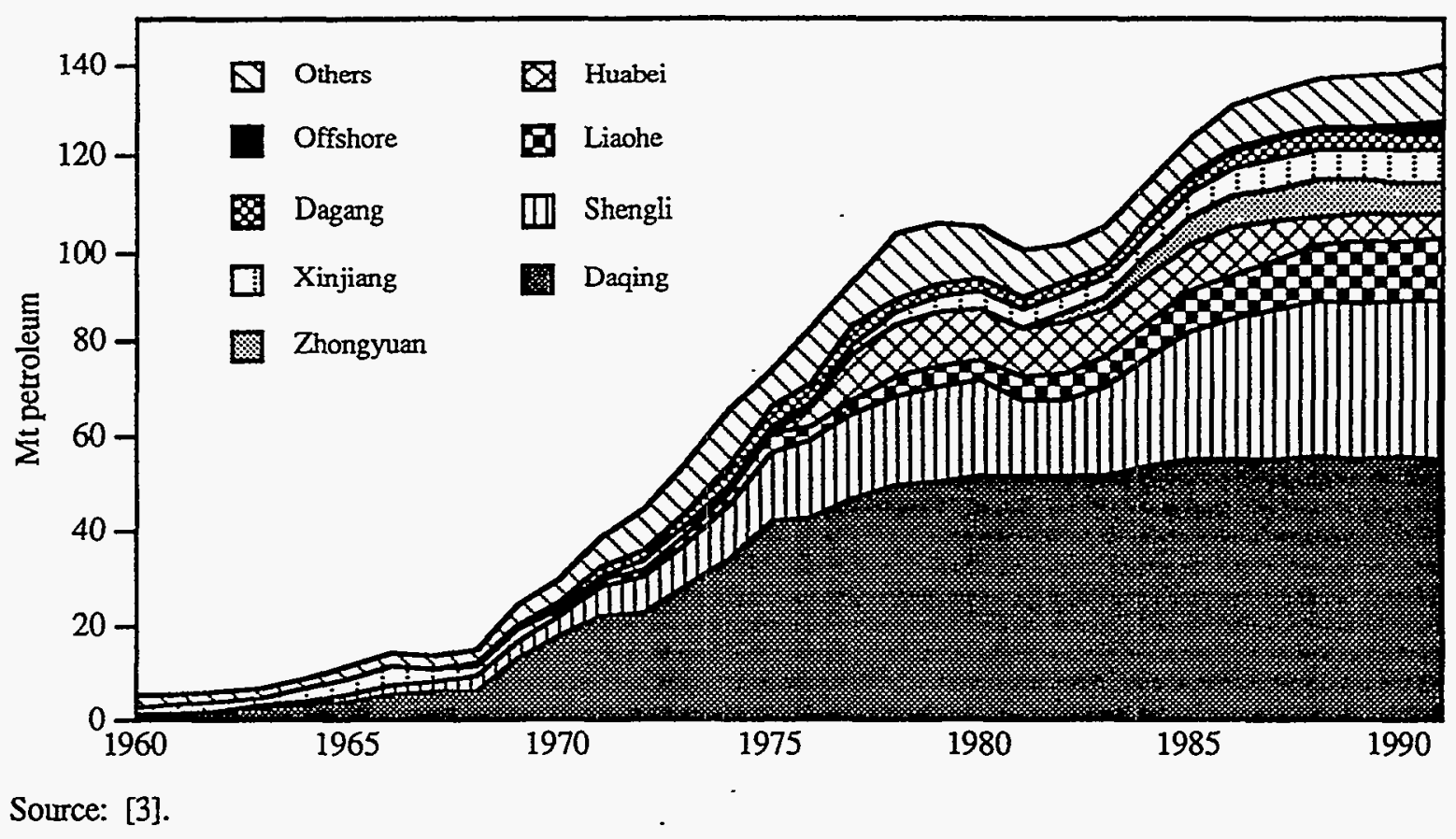

In 1981 the oil industry began to implement the contract responsibility system, a system similar to one employed in the coal sector a few years later. The government "contracted" with the oil and gas corporations for $100 \mathrm{Mt}$ of crude oil annually, which was distributed in accordance with the state plan. Oil output exceeding $100 \mathrm{Mt}$ was sold at free market prices. The incremental income was then placed in an internal fund for oil exploration. A total of 43.4 billion yuan of internal funds accumulated during the period of 1981-1990 was used for oil exploration. At the same time, only 23.2 billion of the state investment was available[25]. A similar contract system for natural gas became effective in 1987. The government contracted for 6.75 billion $\mathrm{m}^{3}$ annually, at a wellhead plan price of 0.13 yuan $/ \mathrm{m}^{3}$. Any "overproduced" gas could be sold at 0.26 yuan $/ \mathrm{m}^{3 .[25]}$ The income from the price differential was to be invested in exploration.

In the late 1980s taxes were added to crude prices. Beginning on January 1, 1988, a 5 yuan/t resource tax was imposed on each ton of oil extracted and was allowed to be factored into the production costs. This was a first-time government-imposed depletion taxation on oil resources. The tax was increased to 59 yuan/ton in 1991 [24].

For a good portion of the early transition period, natural gas production stagnated. One of the largest constraints was the lack of initial capital and the government's strict policies regarding foreign investment. Some natural gas development continued in Sichuan and Liaoning Provinces, the Tarim Basin in Xinjiang, and offshore areas. In recent years, exploration activities in the South and East China Seas have risen dramatically. 
An ongoing policy goal has been to reduce transportation and distribution losses of petroleum products, much of which can be attributed to pilferage. Early on, the central government limited the number of construction permits for refineries with capacities under $2.5 \mathrm{Mt}$ and required small plants (0.5 Mt capacity) to renovate their operations. Rural refineries located around oil fields were eliminated.

\subsection{Economic System Reforms in the 1980s}

Energy development projects were not, on their own, sufficient to solve China's energy crisis. The country's rapid economic growth forced policymakers to experiment with a variety of reform measures to stimulate energy suppliers to meet energy demand without government investment. Economic system reform has touched virtually every aspect of China's political economy. It has been a gradual, halting process that remains far from complete; contradictions between the new and old economic systems, administrative controls, and management methods impede any smooth transition to market-based structures. The changes in behavior required from individuals are substantial, and many years of habits formed under a planning system are not easily broken. Reforms have been successful in promoting, or at least not overly restraining, progress toward economic development goals. In the following sections we discuss price, enterprise management, and investment reforms that have affected energy sector development.

\section{Price Reforms}

Between 1979 and 1990 prices were partially decontrolled in all energy subsectors. In all cases the rationale was the same: market prices were needed to improve profitability in the energy sector and expedite the development of energy resources. However the political sensitivity of introducing market prices in China (especially when higher prices reduced the purchasing power for rural residents) slowed the pace of energy price reform. The central government tended to characterize price changes as "adjustments" rather than "reforms." In addition, not all reforms were based on sound macroeconomic planning. The central leadership described its approach to price reform as "crossing the river by groping for rocks." In other words, reforms were to be undertaken slowly, one at a time, so that each step would be taken without a clear idea of what exactly the next step would be, even though the overall goal was clear. The price reform debate within the energy sector also became mired in interest group politics. Although many policymakers were long ago convinced of the need to eliminate multiple pricing systems, energy price adjustments turned into negotiations among central government agencies and between Beijing and local governments.

Significant progress was made in the liberalization of energy prices by 1990. A two-tiered 
price structure was introduced for coal and petroleum prices, allowing for quantities beyond production quotas to be sold at higher prices. These higher prices were first restricted to within certain ranges of plan prices and were known as indicative prices, but later were allowed to float. Similar reforms were enacted for the electricity sector. Since 1990, the central government has openly begun to back a more radical series of reforms and has announced that significant changes in the energy price system will be implemented before the beginning of $1996^{[27]}$. The following sections provides additional detail by subsector on the details of the various reforms.

\section{Coal Pricing}

In the late 1970s markets and prices for coal were highly controlled, although a certain amount of activity in unofficial coal markets took place and some mines and customers made barter agreements. As early as 1979 losses in the coal sector due to low plan prices were large enough to warrant raising planned prices. although price controls were lifted cautiously, with the idea that coal sold at regulated prices would dominate the market, and coal at unregulated prices would fill in the gaps. In 1982 state-owned mines, which then produced just over half of China's coal, were allowed to sell coal beyond their production quotas at a higher, though still regulated, indicative price. By the end of the decade the indicative price was $100 \%$ greater than the regular quota price. In 1984 price controls on the output of smaller rural mines were lifted and their prices rose, further strengthening this "two-tiered" pricing structure. In the latter half of the 1980 s the central government again raised coal prices based on the thermal value and quality of the coal so that the average price at the minemouth rose from 22.7 yuan/t to 30.7 yuan/t.

Although the difference between prices at the beginning and end of the $1980 \mathrm{~s}$ was dramatic, the original price levels were so low that even with all of the later increases, the regulated price in 1990 still fell below production costs. By 1990 the average production cost at state-owned mines (by this time accounting for $45 \%$ of coal output) was about 60 yuan/t, so that the average regulated minemouth price only covered about $60 \%$ of actual costs. [61] Estimated market price for coal at this time was about 120 yuan/t, based on average returns for capital investment in the economy as a whole ${ }^{[29]}$. Strong concerns about the impacts of higher coal prices made raising prices a politically difficult problem. The bulk of China's nitrogenous fertilizer is produced using coal as feedstock, which is the largest cost in production, so higher coal prices would translate directly into more expensive fertilizer. Already concerned about increasing dissatisfaction in rural areas, the central government has been loath to further burden farmers.

The artificial difference in price between the output of state-owned and rural mines led to unfair competition among coal mines of different ownership types. Struggling under the price ceilings, state-owned mines did not have the capital to invest in increasing output. Relatively high prices for the low-quality products of rural mines, which typically have very low capital requirements, however, encouraged proliferation of such mines, exploitation of marginal 
resources, and irrational utilization of good resources.

Thermal value and quality for most coal types was and still is not fully accounted for in stateset coal prices. Unwashed coal has sold better, since controlled prices still do not fully reflect heat content. Consequently, the practice of coal washing developed slowly and at present less than $20 \%$ of coal is washed [30].15 The use of unwashed coal exacerbates air pollution problems, reduces the efficiency of the end use, and burdens the transportation system with waste material. In many parts of China anthracite prices have been considerably less than those for bituminous coal [61].

\section{Petroleum Pricing}

With the discovery and development of the Daqing and Shengli oil fields in the 1960s, the petroleum sector, and in particularly crude oil, have been quite important to the Chinese government. During the 1970 s and early 1980 s, oil and petroleum products accounted for about a quarter of export revenues. In 1980 China produced 106. Mt of crude oil and $78 \mathrm{Mt}$ of refined products. The combined value of exported crude oil (13.3 Mt) and other oil products (4.2 Mt) was $\$ 4.28$ billion for that same year[31].

Central control of wellhead prices contributed to slow growth in oil production during the 1980 s, even though a two-tiered pricing system was introduced in 1981. The in-plan price of crude oil price from the Yumen oil field in Gansu, for instance, was fixed at 130 yuan per ton-a significant decline in real terms ${ }^{[24]}$ - between 1980 and 1988 . Any output by the national oil corporations beyond the $100 \mathrm{Mt}$ joint "contractual" output was sold at prices approaching world market levels. Although the two-tier system did encourage increased production-crude oil output rose to $137 \mathrm{Mt}$ in 1988 - the increase was much less than production potential during the same period. In 1988 the government raised plan prices by an additional 10 yuan (Yumen oil field prices rose to 140 yuan/ton), a minuscule rise compared to market levels.

By the end of the decade, the declining profitability of the oil industry was all to evident (see Figure 2-9). By 1990 the cost of production (177 yuan/t) had surpassed the average in-plan wellhead price,(167 yuan/t). ${ }^{[15]}$. In addition, distortions in the pricing of upstream and downstream products allowed refineries to profit at the expense of oil fields. The historic ratio of crude oil to gasoline prices in world markets was very stable at 1.0:1.35. Within China, however, the ratios for the plan prices of these products were 1.0:5.8 and 1.0:4.0 before and after 1987, respectively [32]. The divergence between international and domestic prices helps explain the overdevelopment of refining facilities, many of which were small plants built by local governments that hoped to capture the rents created by the irrational pricing system. At the same time, oil exploration and extraction became much less attractive, resulting in a decrease in proven

15 Some coal vendors force customers of unwashed coal to take a small percentage of the shipment in washed coal, which sells at a large premium, in order to improve profits ${ }^{[63]}$. 
oil reserves and a slowdown in oil field development.

Price distortions have existed for diesel and heavy oil as well. The ratios of diesel/gasoline and heavy oil/gasoline production were about 0.93 and 0.6 in the world market, while they were about 0.65 and 0.2 in China ${ }^{[32]}$. The low price of diesel discouraged production, limiting the supply (especially in rural areas) for large trucks which instead must use less efficient gasoline engines.

Natural gas prices were generally too low to encourage significant investment in exploration and development as well. The wellhead price of natural gas was $0.08-0.13$ yuan $/ \mathrm{m}^{3}$ between 1985 and 1990, a price lower than the production cost and the crude oil price in terms of equivalent thermal value ${ }^{[15]}$.

\section{Electricity Pricing}

Pricing policy in the electricity sector has been motivated by attempts to ease the serious electricity supply shortages which plagued much of China. Even though annual growth rates for electricity generation averaged 7.6 percent between 1979 and 1991, electricity shortages throughout the country persist. 16

To encourage electricity production, the central government established a multi-tiered and diversified price system for the sector in $1985^{[24]}$. Prices for the enterprise-owned power plants (China's version of independent power producers) and the small hydropower stations were set higher than the plan price for state-run utilities. Even for state-owned utilities the multi-tier system was intended to have an effect: enterprises that were able to generate even one percent above the contractual level were allowed to raise tariffs on the extra amount by $50 \%$ of the plan price to stimulate further generation.

Capacity and generation shortfalls continued nevertheless. Shortages were especially severe between 1985 and 1987 when several thermal power stations did not receive adequate coal shipments. To defray the effects of these shortages, many enterprises began to contract to transport fuel to their local power stations and in return for preferable rates (based on fuel cost plus generation costs). Another response was for municipalities and industries to band together (sometimes by coercion) and provide "collective funds" to build new plants. In order to encourage the more rapid expansion of capacity, the central government allowed tariffs to be set on the basis of total costs plus a reasonable profit margin. Although the size of the profit margin largely depended on the subjective judgment of administrators, the long-term effect has been significant: collectively funded power plants have provided an increasing share of new generation capacity.

Other steps to rationalize electricity pricing have been taken as well. In 1987, peak load

16 Shortfalls in installed capacity (and subsequent electricity shortages) is common. As an example, shortages in 1988 , after the establishment of electricity price reforms, were still estimated to reach 15-20\% of total demand. [17] 
pricing began to be introduced in some areas. Hydropower prices were varied between dry and rainy seasons to reflect added resource costs. In 1988, state-owned enterprises were levied an added electricity consumption tax of 0.02 yuan $/ \mathrm{kWh}$ for national electric power development, although lighting use and highly electricity-intensive enterprises (e.g., aluminum smelters) were exempted.

Not all of the developments in electricity pricing were positive. Electricity price classifications, as well as rules and regulations for price settings, were confusing and not well established. Rates were still subject to negotiation, and enterprises faced with being cut off from the grid for nonpayment of bills could ask local authorities to intercede with the utility on their behalf. For state-owned utilities the choice of prices was sometimes subjective and prices were generally too low to cover loan interest payments. ${ }^{17}$ On top of this, local authorities added arbitrary fees onto the electricity cost, which further distorted prices. No one could fully understand how many electricity prices there were and how the prices were determined, effectively defeating any incentives there might have been for users to conserve.

In spite of the multiple-tier pricing system, the electricity sector historically was profitable. Part of this can be explained by the frequency of price adjustments, but the real cause has been the difference between the low cost of energy inputs for generation (mainly coal) and the marketbased tariffs set by many power plants in the sector.

\section{Enterprise Reforms}

Historical precedent and institutional rigidities have hindered rapid reform of factor pricing in the energy sector. In the past, social stability and full employment were principal tenets of Communist Party policy. Assuming that one met political obligations, a worker was guaranteed a position of employment. The energy sector has also been subject to full-employment objectives, and as a result, labor costs in the production of energy reached exorbitant levels. During the transition period China's energy enterprises had a very high labor input per unit output; labor costs for coal production account for nearly half of the total cost of coal production and are greater than ten times the labor cost per ton of output in the US [13,14].

An essential ingredient to successful reform of the energy sector was the reduction of the cost of labor in energy production. The most dramatic change in this regard was a salary system reform in 1987, part of the introduction of the "contract responsibility system." Unlike central planning, where wages were fixed and linked to the number of employees, the new system divided wages into several parts related to the employment period, performance, production quota, and position assignment. For the first time the total amount of salary in a state-owned

17 The profit rate for capital investment was $3.7 \%$ in 1989 , down from $12 \%$ in 1980 , while the average loan interest for the electricity sector was in the range of $8-10 \%[33]$. 
enterprise was directly linked to its profit. All new employees were hired based upon contract responsibility. Enterprise managers were now made more directly responsible for the enterprise's survival and development in a more competitive environment and also had to consider improving productivity and optimizing labor operation as a direct ingredient of cost-management. Managers' contracts contained targets for output of product, output value, profit and tax remittances, and other goals. In return, managers were given greater powers over the operations of their enterprises, although crucial decisions regarding investments still remained in the hands of bureaucrats. This set of reforms was the most dramatic step yet toward breaking the "iron rice bowl", the full employment system of the past, and sensitizing state-owned enterprises to market signals.

It is important to note however, that the contract responsibility system, by itself, will not create a fully responsive enterprise management. In the transition to capitalist management systems, enterprises have been hampered by the lack of clear cost-accounting procedures on which to base their decisions. Incorporating such procedures will fundamentally change the way costs are calculated and evaluated in an enterprise. The reevaluation of costs therefore presents a unique opportunity for policymakers to take a comprehensive approach toward energy-related enterprises. For example, exploration costs for all energy sources (coal, oil, electricity) and plant retirement funds should be made explicit costs Realistic rates of depreciation for capital investment should be established. And research and development, as well as environmental externally costs, should also be included in such a revision. ${ }^{18}$ If depreciation and other hidden costs are included in the accounting system, costs for the state-run coal mines and raw oil production as previously calculated are only $60 \%$ and $55 \%$ of the totals obtained using the new accounting costs.

A key to improving the performance of state sector enterprises is exposure to competitive pressure. The reforms of the 1980s allowed entry of many new players in the non-state sector (in coal production and electricity generation, if not in oil production and refining), which have not only filled in the gaps in supply that state-owned enterprises were unable to, but have forced state-owned enterprises to change the way they operate.

\section{Profit in the Energy Sector}

All areas of the energy industry faced dangerous cost increases during the transition period. The coal industry lost profits throughout the 1980s, as shown in Figure 2-9, and relied on substantial

18 The inclusion of the proper costs-accounting should not be overlooked. Before 1985, no capital depreciation was listed in relation to the interest-free investment for the energy enterprises by the central government. Even after 1985 capital depreciation were extremely small. In 1990, the depreciation for the coal, oil, and electricity sectors was only $4.43 \%, 3.18 \%$ and $3.88 \%$, respectively - not even enough to maintain a simple reproduction of sectoral assets. 
governmental subsidies for survival. The figure also illustrates that the petroleum industry, which had made substantial profits in the 1970s and early 1980s, began to incur heavy losses by the late 1980s. Profits from the power sector were partially made at the expense of subsidized coal prices, which lowered the initial cost of generation. Yet even power sector profits were not proportional to the tremendous expansion of power plant capacity during this same period.

\section{Figure 2-9: Profit in the Energy Sector}

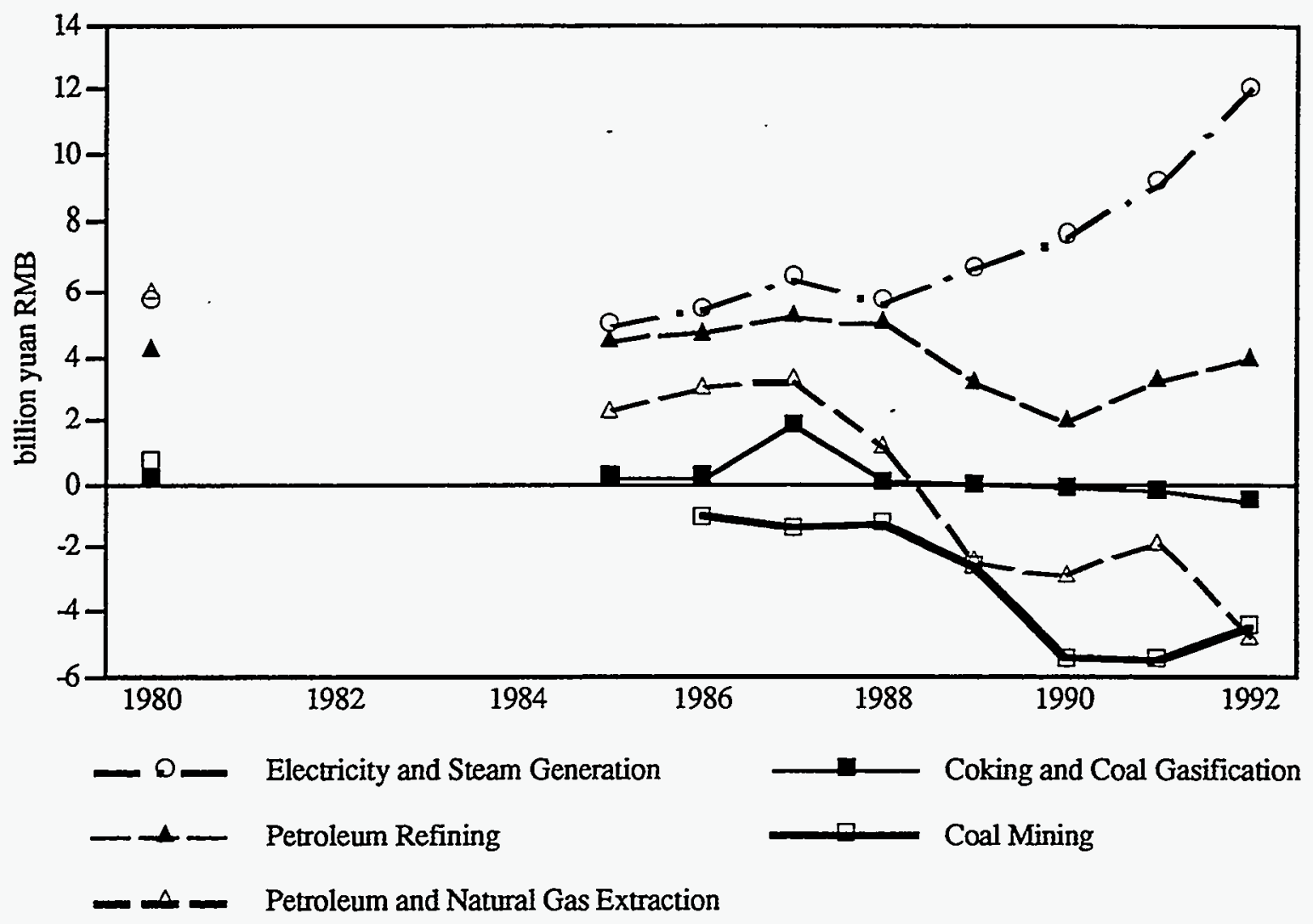

Source: Zhongguo Gongye Jingji Tongji Nianjian,(China Industrial Economy Statistical Yearbook), China Statistics Press, 1993.

The existence of low plan prices for energy combined with high labor and rising production costs has weakened a large financial part of the energy sector. Many believe that the economy will be in tremendous danger if the government and enterprises focus their attention on price adjustment or reform and ignore cost-control measures. Unless such measures are taken, gains from price reform will be offset by rapid production cost increases, and China may lose its lowcost competitive advantage.

Table 2-3 gives a more detailed breakdown of the cost, prices, and profits in the energy sector during the transition period. Pre-tax profit (defined as plan price minus cost) per unit of energy 
production consistently declined throughout the 1980 s, even for electric utilities. Although the Chinese cost accounting system is not comparable to US cost accounting, especially in the treatment of depreciation, and absolute figures should be treated with great care, the decline in profitability is evident. This decline is interpreted by many Chinese policymakers as clear evidence of the need to assist the sector in becoming profitable through more rapid adoption of market mechanisms and structures.

\section{Table 2-3: Before-Tax Production Costs, Plan Prices, and Tax Rates in the Energy Sector}

1980

State-Run Coal Mines
Cost (yuan/t)
Plan Price at Minemouth (yuan/t)
Tax Rate
Crude Oil Production
Cost (yuan/t)
Plan Price at Wellhead (yuan/t)
Tax Rate
Electricity Generation
Cost (yuan/MWh)
Plan Price (yuan/MWh)
Tax Rate

State-Run Coal Mines

Cost (yuan/t)

Plan Price at Minemouth (yuan/t)

Tax Rate

Plan Price at Wellhead (yuan/t)

Tax Rate

Cost (yuan/MWh)

Tax Rate

$\begin{array}{ccc}20.05 & 29.33 & 58.57 \\ - & 22.73 & 30.65 \\ 6.05 \% & 1.22 \% & -4.67 \% \\ & & \\ 43.56 & 61.16 & 177.60 \\ - & 102.00 & 171.00 \\ 55.8 \% & 24.96 \% & 0.16 \% \\ - & & \\ - & 32.66 & 83.9 \\ 20.58 \% & 70.79 & 115.5 \\ & 16.00 \% & 13.03 \%\end{array}$

Source: Wang Qingyi, "Analysis of Energy and Environment Policy in the Transition Period," working paper, the Chinese Energy Research Society, Beijing, 1993.

\section{Energy Supply Investment}

Between 1981 and 1990, energy sector investment gradually increased from $22 \%$ to $30 \%$ of total fixed capital investment in China. Energy, along with transportation, was recognized as one of the bottlenecks in China's development and became the focus of intense and creative efforts to raise money. Accordingly, the energy sector has increasingly relied on multiple sources of investment and has drawn capital from central and local government investment and loans, and from collective, private, and international funds. Figure 2-10 shows the sources of capital construction funds (investment funds for new additions to capacity) for the period 1986 to 1990. The coal industry relied on allocations for nearly two-thirds of its investments, far more than any other subsector, and the absolute amount of its allocations also exceeded that in other sectors. The coal industry's share of bank loans, which are often issued at the direction of government authorities, was also the largest. "Collected funds" (including an enterprises' own funds and funds raised by enterprises through other means) played an important role in providing capital for 
the sector, accounting for nearly half of all investment during the period. The role of collected funds varied among subsectors, being most important in the petroleum and electric power industries. Foreign funds were most important in the petroleum subsector. Significantly, the use of more diversified sources of investment resulted in more investment than was originally planned. Total capital construction investment was almost 230 billion yuan for the period, $28 \%$ more than planned.

Figure 2-10: Investment in Energy Sector Capital Construction, 1986-1990

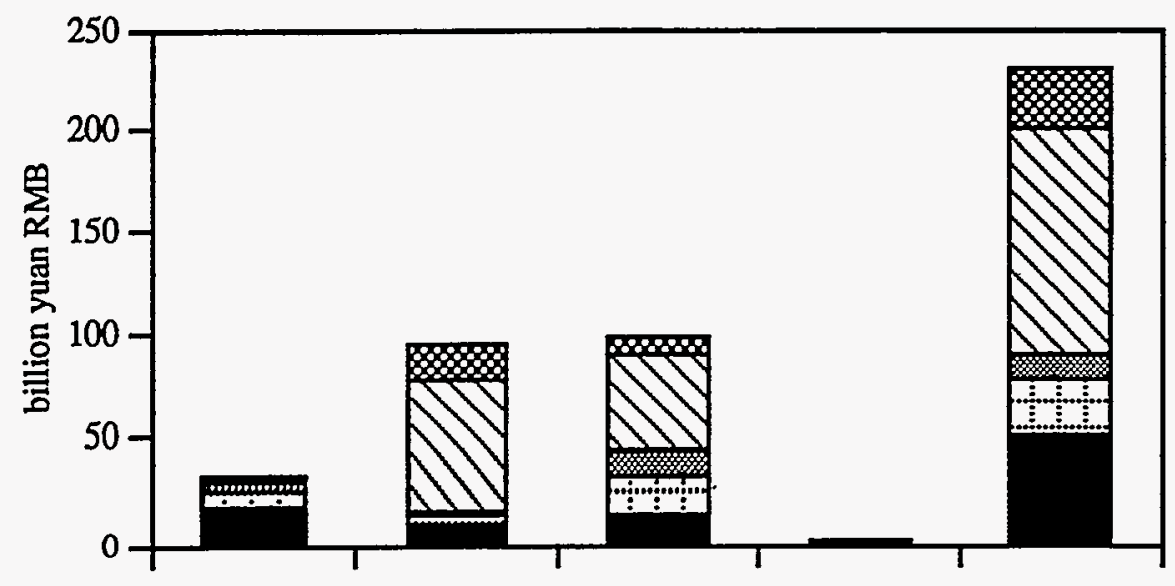

Foreign Funds

$\triangle$ Collected Funds $\dagger$

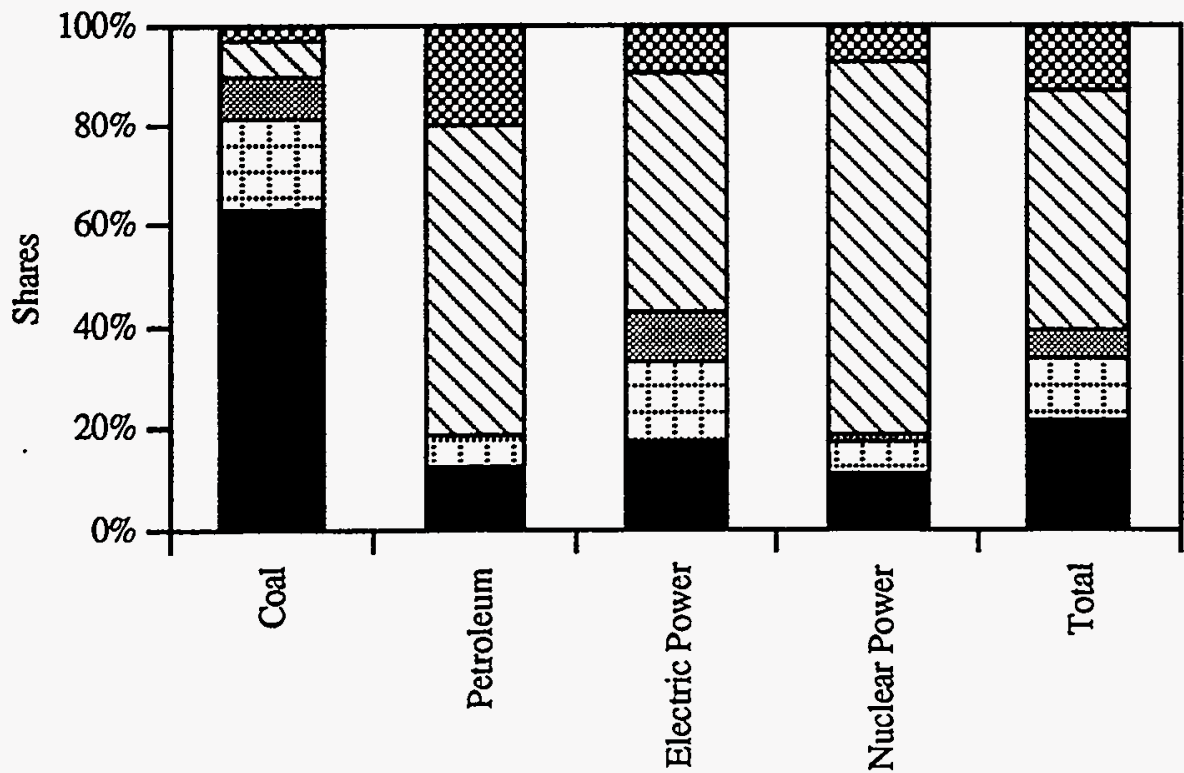

Special Funds

Bank Loans

Allocations

$\dagger$ Includes enterprise funds and funds raised by enterprises through other means.

Special funds are mainly "coal for oil substitution" funds, originally intended to be used to convert oil-fired boilers to coal.

Source: Wang Qingyi , "Analysis of Energy and Environment Policy in Transition Period," working paper, the Chinese Energy Research Society, Beijing, 1993.

In terms of investment, the coal sector has been weakest, and state investment in capital 
construction fell far below planned levels between 1986 and 1990. Instead of reaching the planned $180 \mathrm{Mt}$ /year of production capacity during 1986-1990, actual construction only reached half that amount ( $90 \mathrm{Mt} /$ year).

Investment in the electricity sector has been spurred by government regulations to increase the use of collective funds. In 1985, the State Council issued "A Temporary Regulation Regarding Incentives for Collected Funds in Electricity Development and Diversity for Price Setting." The regulation allowed for the sale of electricity at a floated or market price for certain utilities that accrued private investment into collective development funds. The investors then would receive $70 \%$ of the profit. By allowing an opening for private incentive and investment, this policy helped the electricity sector become more competitive. Between 1986-1990, collected funds for power plant construction ( 16 billion yuan) nearly matched state capital investment (16.5 billion yuan). Since 1990, collected funds have formed the majority of resources for new power development ${ }^{[16]}$.

The use of collective funds as an investment approach to the electricity sector has had mixed results. Although the plants are usually sited in the appropriate areas, they tend to be small ( 300 MW or less) with much lower thermal efficiencies than more optimal larger plants. Hydropower stations proved uneconomic for small-scale needs, and more importantly, did not provide sufficiently quick returns for investors. Finally, even with collective funds, there was still little incentive to build up transmission networks.

For the petroleum sector, attempts to stimulate further investment by allowing oil to be sold at above-plan prices have not been fully successful. A slowdown in proven reserves, a lack of capital investment, and no considerable increase in production caused the oil industry to fall on hard times. Oil industry investment by the state fell from $25 \%$ of the capital construction budget for the energy sector in 1981-1985 to $10.4 \%$ in 1986-1990[3]. At the same time, investment is needed for improving the efficiency of downstream processing, storage, and transportation infrastructure. During this same period, the cost of oil development rose by $70 \%$, resulting in even less allocation of capital for discovering new reserves. Natural gas investment was even worse, receiving only one-tenth of the amount the oil industry received between 1981 and $1990[3]$.

Foreign investment played an increasingly important role during the transition period. A total of $\$ 18$ billion U.S. dollars was invested in the energy sectors during 1979-1991, [15] which helped to accelerate the adoption of more efficient technologies. The electricity sector completed 45 projects with a total capacity of $26 \mathrm{GW}$ in electricity generation by using $\$ 9$ billion of foreign investment. Six billion dollars in foreign funds were invested in the petroleum industry, of which $\$ 3.36$ billion were invested in offshore oil exploration, gaining $1100 \mathrm{Mt}$ of proved oil reserves and 170 billion $\mathrm{m}^{3}$ of natural gas reserves. With $\$ 2.7$ billion invested in the coal industry, 14 projects in the coal subsector were undertaken, yielding an added production of 60 
Mt.[15]

In spite of the substantial government effort to ensure adequate energy supplies and the increasing foreign investment, a lack of capital still restricts development in the energy sectors. Government policy is increasingly turning to the use of outside sources and of placing investment-decisionmaking responsibilities within the enterprises themselves. Other policy measures have included establishing state-run financing entities, "special project" fund allocations, reducing heavy administrative apparatus, and actively encouraging the development of independent energy production entities. Yet the central planning system still dominates the investment activities, which too rigidly isolates subsectors and divisions between the central and local governments for benefit shares. For example, the classification of investment activities by capital construction and technology renovation (the former funds are administered by the SPC and the latter by the SETC) results in the complication of approval procedures, confusion for the administrative management, low efficiency, and contradiction of reforms in the finance, taxation, and accounting systems.

\subsection{Energy-Conservation Policy}

The establishment of institutional structures and the enactment of reforms to stimulate energy conservation in China were important aspects of energy policy during the transition period. As noted earlier, a variety of factors (investment, pricing, transportation bottlenecks, high labor costs) constrained the adequate development of energy to meet China's developmental needs. In a two-track approach, during the 1980s China invested substantial resources in the promotion of energy conservation as a means to reduce future demand. A total of 28 billion yuan was invested over the last decade, which resulted in the conservation of 66 Mtce of capacity in 1990 based on 1980 growth levels, and led to annual average savings of 21 Mtce. In many cases the investment costs for conserving energy were found to be only one-half to one-third of the investment cost for similar capacities for energy development ${ }^{[7,8]}$. The success of these policies has attracted world attention.

Table 2-5 indicates some of the general trends related to energy consumption during the transition period. The rate of energy consumption fell below GNP growth rates during the decade in part due to the success of energy-conservation programs. The framework for energyconservation policies was established by the SPC and related ministries under the supervision and coordination of the Office of Energy Conservation and the State Council. The major policies on energy conservation included: adjusting sectoral structure and product mix for energyintensive industries; substituting coal for oil and reducing the direct burning of oil; using technology to renovate inefficient equipment and processes; eliminating the most grossly inefficient equipment and production processes; issuing energy-consumption standards for 
energy-intensive products; using a system of rewards and penalties to encourage energyconservation activities; providing low-interest loans for some energy-conservation projects; and supporting research and development in energy-conservation technology.

Table 2-5: Energy Consumption Indicators, 1980-1991

\begin{tabular}{|c|c|c|c|c|c|}
\hline & \multicolumn{3}{|c|}{ Annual Growth } & \multicolumn{2}{|c|}{ Elasticities } \\
\hline & GNP & $\begin{array}{c}\text { Energy } \\
\text { Consumption } \\
\end{array}$ & $\begin{array}{c}\text { Electricity } \\
\text { Consumption } \\
\end{array}$ & $\begin{array}{c}\text { Total } \\
\text { Energy }\end{array}$ & Electricity \\
\hline 1980 & $7.9 \%$ & $2.9 \%$ & $6.6 \%$ & 0.37 & 0.84 \\
\hline 1981 & $4.4 \%$ & $-1.4 \%$ & $3.0 \%$ & -0.31 & 0.68 \\
\hline 1982 & $8.8 \%$ & $4.4 \%$ & $6.0 \%$ & 0.50 & 0.68 \\
\hline 1983 & $10.4 \%$ & $6.4 \%$ & $7.3 \%$ & 0.62 & 0.71 \\
\hline 1984 & $14.7 \%$ & $7.4 \%$ & $7.4 \%$ & 0.50 & 0.50 \\
\hline 1985 & $12.8 \%$ & $8.1 \%$ & $9.0 \%$ & 0.63 & 0.70 \\
\hline 1986 & $8.1 \%$ & $5.4 \%$ & $9.5 \%$ & 0.67 & 1.17 \\
\hline 1987 & $10.9 \%$ & $7.2 \%$ & $10.6 \%$ & 0.66 & 0.97 \\
\hline 1988 & $11.3 \%$ & $7.3 \%$ & $9.7 \%$ & 0.65 & 0.86 \\
\hline 1989 & $4.4 \%$ & $4.2 \%$ & $7.3 \%$ & 0.95 & 1.66 \\
\hline 1990 & $4.1 \%$ & $1.8 \%$ & $6.2 \%$ & 0.44 & 1.51 \\
\hline 1991 & $7.7 \%$ & $3.6 \%$ & $9.2 \%$ & 0.47 & 1.19 \\
\hline
\end{tabular}

Source: China Statistical Yearbook 1992, China Statistics Press, Beijing, 1992.

The reduction in consumption is further highlighted in the following tables. Table 2-6 shows that for each fuel, primary energy consumption per unit of economic output generally declined throughout the decade. Energy consumption decreased from $1.413 \mathrm{kgce} / \mathrm{yuan}$ in 1979 to 0.904 kgce/yuan in 1991 , almost $4 \%$ per year ${ }^{[4]}$. Other kinds of energy consumption also showed a similar decreasing trend. 19

The central government's energy-conservation programs targeted the reduction of energy use in China's most energy-intensive industrial subsectors-steel and iron, chemicals, building materials, and power generation. Together, these four subsectors accounted for $10.7 \%, 11.1 \%$, $9.8 \%$, and $3.9 \%$, respectively, of total 1990 energy consumption [3]. Targeted investment in technological renovation to improve manufacturing processes and equipment considerably reduced energy consumption per unit product output. Table 2-7 depicts the decrease in energy consumption of 10 major energy-intensive products during the 1980s. [8, 34] Tremendous progress was made in reducing intensities by factors of two or more in some cases. The most dramatic reductions took place in the steel, aluminum, and ammonia industries.[35-38] Yet physical energy intensities are still high compared to international values

19 Although there are differences in illustrating energy conservation using the index of energy consumption per unit of GNP, such an approach still makes sense in some contexts. 
Table 2-6: Consumption of Primary Commercial Energy per Unit GNP

\begin{tabular}{cccccc} 
Year & $\begin{array}{c}\text { Total Energy } \\
\text { Consumption } \\
\text { (MJ/yuan) }\end{array}$ & $\begin{array}{c}\text { Coal } \\
\text { (kg/yuan) }\end{array}$ & $\begin{array}{c}\text { Petroleum } \\
\text { (kg/yuan) }\end{array}$ & $\begin{array}{c}\text { units: energy/1980 constant yuan } \\
\text { Natural } \\
\text { Gas } \\
\text { (cm } 3 \text { /yuan) }\end{array}$ & $\begin{array}{c}\text { Electricity } \\
\text { (kWh/yuan) }\end{array}$ \\
\hline 1979 & 41.4 & 1.411 & 0.215 & 0.035 & 0.68 \\
1980 & 39.1 & 1.352 & 0.204 & 0.042 & 0.67 \\
1981 & 37.0 & 1.286 & 0.185 & 0.036 & 0.66 \\
1982 & 35.5 & 1.252 & 0.170 & 0.031 & 0.64 \\
1983 & 34.3 & 1.216 & 0.161 & 0.029 & 0.62 \\
1984 & 32.1 & 1.158 & 0.142 & 0.026 & 0.58 \\
1985 & 30.8 & 1.118 & 0.130 & 0.024 & 0.56 \\
1986 & 30.0 & 1.088 & 0.129 & 0.023 & 0.57 \\
1987 & 28.9 & 1.057 & 0.122 & 0.021 & 0.57 \\
1988 & 28.0 & 1.021 & 0.115 & 0.020 & 0.56 \\
1989 & 28.0 & 1.021 & 0.115 & 0.020 & 0.58 \\
1990 & 27.1 & 0.990 & 0.110 & 0.019 & 0.58 \\
$199 \dagger^{\dagger}$ & 26.5 & 0.962 & 0.104 & 0.018 & 0.59 \\
\hline
\end{tabular}

$\dagger$ Estimated based on collected data, LBL.

Table 2-7: Energy Consumption for Ten Energy-Intensive Products: 1980, 1985, \& 1990

\begin{tabular}{|c|c|c|c|c|c|}
\hline Product & Unit & 1980 & 1985 & 1990 & $\begin{array}{c}\text { Percent } \\
\text { Change } \\
(1980-1990) \\
\end{array}$ \\
\hline 1. Fossil-fuel electricity $(>6,000 \mathrm{~kW})$ & $\mathrm{MJ} / \mathrm{kWh}$ & 13.1 & 12.6 & 12.5 & $-4.7 \%$ \\
\hline 2. Steel (total energy) & GJ/ton & 59.8 & 51.0 & 47.2 & $-21.0 \%$ \\
\hline 3. Aluminum (large plants) & GJ/ton & 596.0 & 624.5 & 475.3 & $-20.2 \%$ \\
\hline 4. Ammonia (large plants) & GJ/ton & 41.9 & 40.1 & 39.3 & $-6.1 \%$ \\
\hline 5. Ammonia (medium plants) & GJ/ton & 71.5 & 65.5 & 63.8 & $-1.1 \%$ \\
\hline 6. Ammonia (small plants) & GJ/ton & 88.5 & 69.1 & 66.0 & $-25.3 \%$ \\
\hline 7. Cement (large plants) & GJ/ton & 6.1 & 6.0 & 5.9 & $-3.4 \%$ \\
\hline 8. Caustic soda & GJ/ton & 54.8 & 51.3 & 48.6 & $-11.2 \%$ \\
\hline 9. Calcium carbide (large plants) & GJ/ton & 75.3 & 73.3 & 64.8 & $-13.9 \%$ \\
\hline 10. Plate glass & $\mathrm{MI} / \mathrm{box}{ }^{\dagger}$ & 951.7 & 954.9 & 923.8 & $-2.9 \%$ \\
\hline
\end{tabular}

A box contains $50 \mathrm{~kg}$ of plate glass.

Source: [24] 
Many 2 the energy-conservation programs implemented during the transition period led to remarkable energy savings and required less investment than the equivalent development in new supplies. In addition to the energy-intensive industrial conservation efforts, other successful programs included cogeneration, promotion of district heating systems, manufacture of honeycombed coal briquettes, coal washing, use of heat waste in power generation, boiler and furnace retrofitting, renovating industrial boilers and furnaces, and the manufacture of higher efficiency equipment ${ }^{[39-44]}$.

These policies were implemented in spite of the uncertainties surrounding macroeconomic reform and the slow progress toward the introduction of market mechanisms within the energy sector. Necessity dictated that China implement energy conservation as a means to respond to the challenge of maintaining growth in the face of slower than needed expansion of energy supply. Some experts suggest that the existence of centralized institutional structures was partly responsible for the success of the conservation programs. ${ }^{[45]}$ To some degree, this appears to be true, but centralized control is no longer feasible on such a large scale. However, it appears that decentralization of authority for investment in energy conservation to local and municipal entities has resulted in lost conservation opportunities. One of the most glaring examples in the power sector is the proliferation of small (under $300 \mathrm{MW}$, and often as small as $10 \mathrm{MW}$ ) thermal power plants. In this sense the central government's policy of promoting local power development is at odds with its conservation policies. ${ }^{[46]}$

Unless China continues to push for a more complete and more radical transformation to a market-based economy in the energy sector, more conservation opportunities may be lost. Rather than implementing "top-down" or command-and-control conservation policies, the energy sector will need to develop the appropriate macroeconomic environment where energy managers will be able to respond to real market signals and thereby acknowledge and act upon the benefits of conservation investment in the context of enterprise management.

\subsection{Rural Energy}

From 1949 to 1979 rural population increased 1.6 times, but commercial energy consumption remained relatively flat. ${ }^{[19]}$ Increasing fuel needs were met through consumption of biomass resources, including firewood, crop wastes, grasses, and dung. Increasing numbers of trees were cut for cooking fuel, and even grasses and tree roots were dug for fuel. The results were serious deterioration in soil fertility, as biomass was not returned to fields as with traditional farming methods, and other environmental impacts.

The Chinese central government conducted the first national survey of rural energy in 1979 to provide a basis for its effort to slow environmental degradation. Table 2-8 displays the results of the 1979 survey and compares them to data gathered in 1990. Although agricultural output 
value had increased as much as four times since 1949, at the end of the 1970s biomass was still the principle fuel in rural areas, accounting for more than $70 \%$ of total energy use. The same 1979 survey discovered that $47.7 \%$ of the total households in rural areas lacked cooking fuels for 3-6 months ${ }^{[48]} .20$

Table 2-8: Rural Energy Consumption by Sector 1979, 1990

\begin{tabular}{|c|c|c|c|c|c|c|c|}
\hline \multirow[b]{2}{*}{ Energy Type } & \multicolumn{3}{|c|}{1979} & \multicolumn{4}{|c|}{ unit: EJ } \\
\hline & $\begin{array}{l}\text { Agriculture } \\
\text { \& Industry }\end{array}$ & Residential & Total & Agriculture & Industry & Residential & Total \\
\hline Straw & - & 3.332 & 3.332 & - & - & 3.857 & 3.857 \\
\hline Dung* & - & 0.185 & 0.185 & - & - & 0.095 & 0.095 \\
\hline Wood & - & 3.041 & 3.041 & - & - & 3.852 & 3.852 \\
\hline Electricity $\dagger$ & 0.395 & 0.091 & 0.486 & 0.198 & 0.730 & 0.062 & 0.990 \\
\hline Oil Products & 0.374 & 0.044 & 0.418 & 0.171 & 0.606 & 0.036 & 0.812 \\
\hline $\mathrm{Coal}$ & 0.749 & 0.955 & 1.704 & 0.516 & 3.875 & 1.884 & 6.275 \\
\hline Total & 1.519 & 7.649 & 9.168 & 0.884 & 5.211 & 9.787 & 15.882 \\
\hline
\end{tabular}

* 1990 figure for dung unavailable; substituted 1987 dung consumption.

$\dagger$ In 1979 electricity for production was split nearly evenly between agricultural and industrial uses $(0.202$ and 0.193 EJ respectively).

Source: Rural Energy Planning, Xu Xichun and Zhang Zhengmin, eds., Chinese Statistics Press, Beijing, 1990; Energy of China, September 1993, p. 20.

By 1990 fossil fuel use in burgeoning rural industry had pushed the share of biomass down to less than 50\%. The residential sector was still the largest consumer, with $60 \%$. Biomass remained the principal fuel, but newly developed commercial energy sources were significant as well. ${ }^{21}$ Residential electricity consumption grew from $49 \mathrm{kWh}$ per capita in 1979 to $102 \mathrm{kWh}$ per capita in 1990, an increase of more than $200 \%$ [3]. Among commercial energy, the shortage of electricity has been particularly acute.

Before 1979 policies guiding development of rural energy supplies were relatively lacking, even though more than $70 \%$ of China's population still lives in rural areas. The major exception was the central government's attempt in the 1970s to alleviate rural energy shortages through subsidization of a large-scale biogas digester program-especially in Sichuan Province. The

20 With estimated cook stove efficiencies of $12 \%$, the amount of the useful energy was $4500 \mathrm{Kcal} /$ day per household, the actual useful energy consumption in 1979 was only $3500 \mathrm{Kcal} /$ daily for each household, which meant that there was a lack of 3 months daily fuel on average, and sufficient energy was not available in rural areas [48]. 21 Commercial sources include coal, hydro, and solar. In 1991, the output of coal production in the small-sized coal mines was $400 \mathrm{Mt}$, the capacity of the small-sized hydropower stations reached $13.85 \mathrm{MW}$ and generated $37.3 \mathrm{TWh}$ of electricity across the country. In rural areas, there had been 4.75 million biogas digesters, 1 million square meters of solar collectors, 0.33 million square meters of solar green houses, 0.45 million square meters of solar passive houses, 120 thousands of solar cookers and 110 thousands of micro-sized wind mills. 
program aimed to reduce the overuse of biomass fuels by expanding the penetration of digester into the countryside. [49] More than 100 million yuan were poured into the program and over 7 million digester had been built by 1979 . At least one-third of the digesters operated poorly, however, because of poor design and materials, which slowed biogas development ${ }^{[50]} .22$

Since 1979 major efforts have been aimed at increasing the efficiency of biomass fuel use and making fuel wood more available. In the early 1980s a well-funded program aimed at introducing improved biomass cookstoves into rural households. These stoves had been distributed widely throughout China, and may have relieved some pressure on biomass resources. The rate of increase of biomass consumption for residential fuel was certainly below that for coal, but that may also be due to fuel switching. There is anecdotal evidence that many households with improved biomass stoves do not use them, but instead burn the coal that has become increasingly available from small rural mines.

Annual sustainable consumption levels of firewood are estimated to be 117 million tons (66.8 Mtce), but actual consumption during the 1970s was up to 180 million tons per year, exceeding sustainable amounts by 63 million tons annually. Soil and water erosion damaged a total area of over 1.5 million square kilometers in 1979 and conditions have continued to deteriorate. Although the Chinese government undertook large-scale afforestation projects, tree coverage in China barely increased from $12.7 \%$ in 1949 to about $13.4 \%$ in 1990 , partly because of neglect of seedlings and premature harvesting. Without the massive tree planting, the tree coverage would have dropped to $10 \%$ of total acreage) $)^{[47]}$.

The expansion of rural industry, which experienced double digit growth rates in the 1980s, has contributed to a significant increase in rural energy use (see Table 2-9). Output value grew more than tenfold over the decade and accounted for $54 \%$ of total rural output by 1990 . Some rural enterprises in coastal areas now rival large state-run enterprises in scale and output. If such trends continue, rural areas will have a tremendous impact on future energy supply and distribution patterns.

Table 2-9: Indicators of Rural Industrial and Enterprise Growth

\begin{tabular}{|c|c|c|c|c|c|c|}
\hline & \multicolumn{2}{|c|}{ Energy Consumption } & \multicolumn{2}{|c|}{$\begin{array}{l}\text { Rural Industrial Output } \\
\text { (current value) }\end{array}$} & \multicolumn{2}{|c|}{$\begin{array}{l}\text { Total Rural Output } \\
\text { (current value) }\end{array}$} \\
\hline & Mtce & $\mathrm{EJ}$ & billion yuan & billion US $\$$ & billion yuan & billion US \$ \\
\hline 1979 & 32.2 & 0.94 & 54.8 & 36.5 & 230.0 & 153.0 \\
\hline 1990 & 177.8 & 5.21 & 895.7 & 186.6 & 1661.9 & 347.7 \\
\hline
\end{tabular}

22 See Smil, 1993, for more details on this and other rural energy issues [64]. 
Compared with the rural industrial and household sectors, energy consumption in agriculture increased slowly. Agriculture relies more on technology and labor inputs, and agricultural energy use appears to be much more sensitive to price increases. During the 1980s, the central government's "family responsibility" policy (which originated as an innovation in poor areas in southern China, and replaced the communal responsibility system) encouraged the use of laborintensive agricultural practices. For now this policy has successfully reduced agricultural energy intensity. In the long term, however, both intensity and energy use are expected to increase as more capital equipment penetrates the sector.

\subsection{Evaluation of Policies in the 1980s}

The enactment of market oriented reforms in the energy sector during the transition period has not been an easy task. Many of the policies and approaches that were attempted-sectoral contract system, partial freeing of prices in the multi-tier system, increasing the local and municipal roles in energy investment-led to some positive near-term achievements. The continued presence of, and in some cases domination by the central planning system, however, contributed to structural inefficiencies.

The official attitude toward market reforms in the energy sector has been to promote a very slow approach, which could worsen development of the sector in the long term. If substantial opposition develops over the supply and distribution problems engendered from a "halfway" approach, decisionmakers are likely to return to the framework of the old system to meet the ensuing shortages. Any sectoral reform program needs both articulate orators and well-stated goals. Yet market reforms in China's energy sector have not proceeded in a coherent fashion. Reforms, strategies, and specific programs were developed independently for each subsector, and there has been little effort to integrate these reforms into a unified framework and message. The result is that guidelines for enterprise managers have often been confusing and even conflicting.

In general, many energy policies and their implementation successfully contributed to improving the productivity and efficiency of the energy sector. Specific policies failed because of either poor conceptualization or poor implementation in the hybrid, quasi-market structures of the energy sector. Table 2-10 lists the main (though by no means all) energy-related policies adopted in the 1980s. The third column of the table indicates the opinion of Chinese energy experts as to effectiveness of the various policies. Major themes of the evaluations include the following:

\section{- Weak energy price reform}

Energy price reform during the decade was slow and unfocused. Social and political considerations delayed any rapid reforms, weakening the sector in the long term by reinforcing 
suboptimal energy use and consumption patterns. Incremental adjustments distorted market signals in energy production, distribution, and utilization activities. The price system also discriminated against certain energy customers and limited energy enterprises' ability to survive and develop.

\section{- Poor investment signals}

In spite of efforts to diversify sources and to increase investment, the energy sector still lagged behind other growth sectors in terms of its attractiveness to domestic and foreign investment. Capital productivity continued to be much lower than the average of industrial sectors overall, in large part because of incomplete price reform. In 1990 capital productivity in the energy sector was 43 yuan per 100 yuan of capital, while the figure for industry as a whole was 130 yuan.

\section{- Poor implementation mechanisms}

Although many of the policies developed were well intentioned, they suffered from a lack of supervision and implementation mechanisms. For example, although the government had issued a number of regulations to eliminate the most backward processes and equipment, the use of such antiquated equipment (especially in rural areas) persisted.[38] Policies based on the central planning paradigm ran afoul of important elements of economic system reform, i.e., those that gave greater decision-making power to localities and enterprises. Since command and control approaches to energy conservation are becoming less effective, the central government will need to pay more attention to achieving its objectives through the use of market mechanisms, such as the use of taxation and investment credits.

\section{- Lack of development of clean energy sources}

Although official energy technology policy emphasized the development of hydropower and the equal treatment of natural gas and oil, the reality was much different. Hydropower capacity as a percentage of total power capacity fell from $31 \%$ in 1980 to $25 \%$ in 1991 . Investment in hydropower was only one-sixth of total investment in the electric power industry between 1986 and 1990; between 1976 and 1980 hydropower accounted for one-third of investment in electric utilities. One barrier to hydropower development has been the disregard of relative environmental impacts of hydroelectric and thermal alternatives. Rather, the primary criterion in project choice has been the ability to achieve large, short-term returns on investment. Similarly, the pace of natural gas exploration and development has lagged, largely due to the low plan price for gas. In the Sichuan region, the wellhead price in 1991 was only $66.5 \%$ of cost. Unless these patterns are reversed, continued weak investment in clean energy sources will increase the risk of long-term environmental damage to China and to the world. 


\section{- Lack of attention to least-cost supply}

One of China's traditional guiding principles in energy development has been self-sufficiency, especially when the government had little ability to generate hard currency. Unfortunately, this approach still persists and has caused the government to overlook the potential of importing cheaper (and cleaner) energy sources to meet demand in the current period. One lost opportunity took place when China did not take advantage of low oil prices during the glut in world markets in the mid-1980s, even though domestic demand was increasing during the same period. Given the rising costs of petroleum development, oil importation is an increasingly attractive option.

\section{- Imperfections of the contract responsibility system}

Although the contract responsibility system established within the various subsectors throughout the 1980s helped improve production, the system is not a feasible long-term mechanism compatible with a market-based framework. Eventually, the contract system weakens costcontainment measures and inhibits independent competition for energy development.

\section{- Uniqueness of rural energy situation}

Rural enterprises usually have little opportunity to procure energy at the state-controlled prices and must instead buy high-priced energy products. Because of electricity shortages, small coaland oil-fired power plants, at which generation costs are much higher than large-capacity plants, were rapidly constructed. Electricity prices that have been high for years have had little effect in stimulating conservation. Rather, administrative regulations and enforcement of energy savings should be further strengthened to meet the diversity in the enterprise spectrum.

\section{- Momentum for nuclear electricity}

In spite of the great expense involved, Chinese planners began to put large amounts of funding into the development of nuclear power plants. The central government has been supported by, among others, administrators of regions where sufficient electricity is lacking, environmental protection officials concerned about air and other pollution from thermal power plants, and advocates in China's. energy research community. No policies were announced to prepare for nuclear fuel and waste transportation and processing. 
Table 2-10: Review of Key Energy Policies, 1979-1993*

$\begin{array}{lll} & \text { Impact } & \\ \text { Policy Description } & G \text { S P } & \text { Evaluation }\end{array}$

7/8/79 "Joint Venture and Joint Venture Management Act" allowed foreign investment in energy sectors.

1980 Change in China's energy strategy to give the same priority to energy supply development and conservation, and to give special treatment to conservation in the near term.

1981 Contract responsibility for most (100 Mt) of oil production at petroleum industry enterptises.

1982 State Council determined to develop Shanxi Province as a energy/chemical base.

1982 Prohibition of coke production in rural areas.

$12 / 82$ Construction of Daya Bay nuclear power station.

1983 State Council promulgated policy to simultaneously promote development of state-owned, collective, and private coal mines of all scales. Also promoted development of small coal mines without mechanisms for resource conservation.

1983 Dissemination of improved biomass-burning stoves G in rural areas.

9/83 State Council decided to build Daqing railway dedicated to coal shipments.

$12 / 83100$ counties were selected for demonstration projects in rural electrification.

1984 State Council established its Office of Rural Energy G Development.

1984 Contract responsibility system introduced to stateowned coal mines.
S Diversified investment sources, encouraged introduction of advanced technology and management methods. Further improvement needed in regulations and rules.

G More efficient use of the limited capital. Dual benefit of improving energy utilization efficiency and reducing environment pollution. Implementation initially good.

$S$ Encouraged enterprises to increase production.

S Good direction for policy but more specific programs need to be developed.

P Good policy but very weak implementation.

Leaders consider nuclear power to be an important energy source for coastal areas, but adequacy of safety and waste disposal mechanisms have not been publicly discussed.

S Greatly alleviated coal supply shortages, but small mines were inefficient, wasted resources, and suffered from poor worker safety.

Dual benefit: greatly improved utilization efficiency of biomass fuels and reduced pressure on limited biomass resources.

A necessary investment for alleviating coal transportation bottlenecks.

Speeded adoption of appropriate technologies.

Important institutional change for responding to critical rural energy problems.

$S$

Encouraged enterprises to maximize production, but still subject to weaknesses of central planning methods for production control.

\footnotetext{
*This column contains the opinions of Chinese energy experts on the appropriateness and impact of policies' formulation and implementation. $G=$ Good, $S=$ Satisfactory, $P=P$ Poor.
} 


\section{Table 2-10 (continued): Review of Key Energy Policies, 1979-1993* \\ Policy Description \\ Impact* \\ G S P \\ Evaluation}

1984 Acceleration of electricity development in coastal G areas.

1984 Tax rate imposed on electric power industry increased by $25 \%$.

1985 Temporary provisions for encouraging electric power development with enterprise funds (including those raised by enterprises from outside sources) and price diversification.

1985 Establishment of Huaneng Electric Power Development Corporation with special funds for substitution of oil for coal.

9/23/85 Development strategy in energy industry centered on electricity generation.

1/86 State Council issued temporary provisions for energy conservation.

3/19/86 "Mineral Resources Act" became effective.

3/26/86 State Council issued environment protection and $G$ management guidelines for energy sector projects.

5/86 Outlines for technology policy in 12 key energy fields drawn up.

9/5/87 "Air Quality Protection Act" issued.

1987 Contract responsibility system for natural gas production implemented in petroleum industry.

12/87 Special tax for electric power development imposed on consuming enterprises.

1988 Adjustment to plan and market well head oil prices and imposition of a tax on oil reserves development.

3/89 Prohibition of development of small thermal (condensing) power plants.

8/8/89 Incentive given to utilize low heat-value fuels and $G$ develop cogeneration.
Helped to diversify investment sources and stimulate electricity development.

P Slowed expansion of electric power sector.

S Diversified investment sources, but complicating price system by increasing subjectivity of pricing.

S Significant contribution to country's energy development, but Huaneng still reliant on public support.

S Necessary shift in focus, given that electricity shortages still exists today.

Important standardization of energy conservation activities.

Established law governing utilization of fossil fuels.

An important advance that increased emphasis on environmental protection.

S Well-conceived guidelines, but few specific implementation mechanisms.

S Good first step, but more teeth needed in enforcement. Air pollution is still serious in most urban areas.

S

Encouraged enterprises to increase production but still subject to weaknesses of central planning methods for production control (e.g., natural gas price still very low).

S Increased investment resources. Impacts across subsectors still unclear.

S Gave incentives for enterprises to increase production, but bolder price reform still needed.

S Good policy but little implementation. Rapid and widespread construction of small (e.g., $10 \mathrm{MW}$ ) thermal plants continued.

Policy helped accomplish both objectives.

*This column contains the opinions of Chinese energy experts on the appropriateness and impact of policies' formulation and implementation. $\mathrm{G}=\mathrm{Good}, \mathrm{S}=$ Satisfactory, $\mathrm{P}=$ Poor. 


\section{Table 2-10 (continued): Review of Key Energy Policies, 1979-1993*

Policy Description \\ Impact* \\ G S P \\ Evaluation}

Date

1989 "Policies and Strategies in Energy Sectors" issued.

1990 Reiteration of policy of making electric power development the focus of energy sector development.

1990 Program for combined development of coal and electric power begun.

$7 / 1 / 90$ Increase of maintenance allowance from $1.4 \%$ to $2.5 \%$ of enterprise output value announced.

1991 "Economic Reform for the Next Decade and the Eighth Five Year Plan" issued.

1991 Initiation of second round of contract responsibility system in electric power sector

1991 "Regulations for Energy Conservation in Coal Mines and Power Plants" issued.

$7 / 1 / 91$ Depreciation rate for power plants increased from $4.5 \%$ to $5.5 \%$

12/91 Independent electricity development corporations organized in 5 regional electricity grids

1992 Policies for replacing small power plants with large ones in electric power sector (reiteration of policy from 1980s) and promoting energy efficient pumps and fans in coal sector

1992 Fees for energy capital construction imposed.

1992- Price controls on directly planned coal supply 1993 relaxed and coal prices for mines in the northeastern and the eastem regions freed.

1/93 "Promote Energy Conservation and Rational Resource Utilization" issued.

1993 Prices of oil from certain oil fields allowed to rise to $G$ international oil market levels.

1993 Further acceleration of electric power development G encouraged
G
First formulation of policies for short- and long-terms plaming of pricing, financing, taxation, credit and trade.

Helped alleviate severe electricity shortages. but lacked coordination among energy subsectors.

Resulted in more efficient for coal-fired electricity projects and better use of investment funds.

Cost formulation policy helped improve operating conditions.

Continued economic reform policies at a slow pace.

Incrementally strengthened incentives to increase-electricity generation, but still not far removed from old system.

Further strengthened energy conservation efforts in energy sectors. Allowed quicker payback for capital
investments.

Decentralized control of electricity generation and strengthened competition.

Promoted.specific cost-effective measures for energy conservation.

P Collection of fees weakly implemented, and revenues often not allocated to intended uses.

Important step toward market adjustment. Increased coal supply and may have stimulated energy conservation through price signals.

Further emphasized efficient energy and resource utilization but lacked funancial support.

Improved finance situation of the oil industry.

Necessary to meet rapidly increasing demand.

*This column contains the opinions of Chinese energy experts on the appropriateness and impact of policies' formulation and implementation. $G=G o o d, S=$ Satisfactory, $P=$ Poor.

Sources: "Experience and Lessons of China's Energy Policies," working draft, Chinese Energy Research Society, July, Beijing, 1992; Zhou Shaoqian, "Review of the Energy Industry in the Past Five Years," Energy of China, Vol. 44, No. 8, pp. 15-21, August 1993. 


\subsection{Developments Since 1990}

\section{Continued Economic System Reforms}

Deng Xiaoping's tour of southern China in 1992 spurred a second wave of economic transition, which had been stalled since 1989. After the tour, economic growth skyrocketed to the levels seen today. The strong growth reemphasized the need to provide more commercial energy supplies. At the same time, central planners themselves were less able to predict and effectively react to the rapid growth. ${ }^{23}$

To defray a second domestic energy crisis, reform in the energy sectors accelerated. National and regional futures markets for coal and oil were established across the country. The plan price of coal was allowed to float at market levels in some regions and more oil was put on the free market in 1993. At the same time, the central government issued a new set of laws and regulations to push state-owned enterprises into the market and make them responsible for their own economic activities. The ensuing competition has already begun to have a dramatic effect. For example, 15 of the 34 state-run coal mines in Guangdong Province will be closed in the next five-year period, resulting in about 13,000 unemployed.

As in the past, some unique solutions are being tried at the local rather than central level. In 1992, the administration of Shanxi Province proposed a regional cooperation plan to develop new electricity capacity. Drawing upon its vast coal resources, the regional group plans to build $13 \mathrm{GW}$ of new capacity at the minemouth requiring an investment of 50-60 billion yuan. A joint venture agreement between the Shanxi and Jiangsu Provinces was issued to construct the Yangcheng power plant with $4 \mathrm{GW} .{ }^{24}$ Part of the success of the renewed economic activity will rest on the ability to generate and rapidly assimilate large amounts of capital to construct the power plant facilities. Since the utility sector will play a central role in this process (especially the construction of transmission networks), the provincial laws established to break the monopoly in the utility sector will need to be vigorously enforced in order to stimulate the new regional market for independent power suppliers.

In tandem with these domestic changes, China has continued to seek capital and expertise from abroad to assist its escalating growth. For example, in October of 1992 Sinopec opened an additional 11 regions to foreign companies for oil exploration, and onshore and offshore blocks (sometimes even those claimed by neighboring countries) continue to be opened up to foreign participation in exploration. The rise of foreign investment is increasing the pressure to

23 For example, China's Eighth Five-Year Plan (1991-1995) was based on the extremely conservative prediction of an annual growth rate of only $6 \%$. Using such low numbers in the Plan, it was difficult to properly evaluate the country's future energy supply needs.

24 People's Daily (Domestic Edition), June 6, 1993. 
accelerate price and market reforms that were begun earlier in the transition period, as investors attempt to reduce the riskiness of their ventures.

Continued energy price reforms (see the following section) are seen as key to attracting investment from domestic as well as foreign sources. In 1990, for instance, the electric power authority in the special economic zone of Shenzhen allowed power generators to charge market prices and recover up to a $15 \%$ return on investment from new facilities in order to alleviate shortages. Such private power producers are allowed to form corporations and issue stocks to obtain capital. This action has already reduced electricity shortages (though often by simply increasing the pressure on diesel supplies, since much of the rapidly built new capacity is from small and often imported diesel sets). Capital shortages may still restrict short-term development in energy sectors, however. The government has continued to push its new investment policies but will need to improve other macroeconomic conditions before they more effectively come to fruition.

State-owned enterprises continue to be reformed, albeit slowly. In July of 1992, the State Council issued "Regulations of Transformation in Management Mechanism for State-Owned Enterprises," intended to expand the scope of independent action of enterprise managers. There has been considerable resistance from both the government administration and, not surprisingly, enterprise managers. The administration is reluctant to relinquish the power to control decisions on investment, personnel, imports and exports, and price setting. Some enterprise managers still lack the ability to operate effectively in a market environment, and those in charge of moneylosing ventures are unwilling to forego the financial support that accompanies government control.

The introduction of a new tax system at the beginning of 1994 may have major impacts on enterprise performance. Instead of negotiating tax-remittance targets, as under the contract responsibility system, enterprises will now be assessed a value-added tax, the rate of which is to be subject to less negotiation. If effectively implemented, this tax may further shift managerial incentives toward producing at least cost and adjusting the scale of production to the most efficient level, and away from attaining a given level of output. This reform will not in itself rationalize enterprise behavior, but it is a necessary step.

\section{Energy Prices}

In early 1993 the central government announce that prices of all coal from all mines would be deregulated within three years; later that year deregulation was promised by the end of 1994 . In that year all coal prices in northeastern and eastern China and in Hunan Province were allowed to float freely, and restrictions on prices of washed coal (except to town gas plants) and utility boiler coal in all areas were lifted. The immediate impact on market coal prices in areas where 
prices were freed was not great, and rises of only 5 to 30 yuan/t were reported in the Northeast. [61] In many areas where controls are still in effect, market and plan prices are converging. In some areas there is now a buyers' market for coal, where agents from mines solicit orders from industrial customers. [63] The government also plans to stop subsidies to all mines by the time prices are completely deregulated. This promises to be a painful transition for mines, some of which in the Northeast are in arrears in paying their workers.

Problems with China's distribution system continue to distort coal prices. A wide variety of charges and taxes are levied by distributors, local authorities, ports, and any other entity that can extract a fee. In 1992, for example, the minemouth price of high-quality sorted steam coal from Datong, Shanxi, was 78 yuan/t after all fees and taxes were included. The prices for that same ton of coal at the ports of Shanghai and Guangzhou were 220 to 230 yuan/t and 260 to 270 yuan/ton respectively; actual shipping costs to both destinations totaled about 90 yuan per ton and 110 yuan per ton respectively, including transshipment. ${ }^{[61]}$ Pilferage and adulteration also raise the effective price of coal; factories regularly receive shipments of coal that may be $10 \%$ or more underweight, or that contain a high percentage of dirt and rock, but generally have no recourse and must pay mines for the full amount ordered. [63]

Coal users in many areas believe that coal prices have basically stabilized, and pressure to reduce costs through cutting back on coal use is not heavy. The already high and steadily increasing cost of electricity in many areas, on the other hand, is of concern to all customers. In some coastal areas, industrial enterprises that can afford to seek ways to self-generate. Industrial users see value in electricity-conservation measures, and demand for reliable, though expensive, efficient equipment such as adjustable-speed drive motors is increasing. ${ }^{[63]}$

In 1993, power plants that began operation in 1992 were allowed to set their prices based on a formula for return on investment. This measure was intended in part to improve the attractiveness of investment in the sector. Pricing policies aimed at regulating demand continued to suffer from uneven application. Peak load pricing, for instance, continues to be advocated, but implementation has been slow, even in coastal areas where the economic system and other reforms are typically most advanced.63] The equipment needed.to monitor loads at various times of day has not been installed at most industrial enterprises, and load management consists of agreements between utilities and customers, e.g., for large industrial users to shift electricityintensive operations to night hours during the summer months when cooling loads are high, or to shut down during periods when agricultural use is high.

In the middle of 1993, Sinopec began pay the world market crude oil price to all suppliers except the Daqing, Shengli, and Liaohe oil fields. Domestic oil prices will be adjusted to nearly world market levels by 1995 . In mid-1994, the average price for domestic crude was about 750 yuan/t, or about two-thirds of the international market price. ${ }^{[65]}$ Prices for oil products, especially gasoline, have increased steadily, at times in some areas to levels far higher than 
"ternational price levels. ${ }^{[51]}$ Currently oil product prices have leveled off, due in part to large s $\mathrm{ks}$ that accumulated at the end of 1993.

Natural gas prices have risen in recent years, but not by a large margin. Natural gas from fields in Sichuan was selling for between 220 and 240 yuan/tcm, and between 130 and 330 yuan/tcm in other parts of the country. ${ }^{[61]}$ Gas prices are still highly regulated and are set differently depending on the type of customers, with fertilizer plants typically receiving the lowest prices.

\section{Institutional Changes: Dissolution of the Ministry of Energy}

A major reorganization of the institutional structures in the energy sector was begun in 1993 and is planned to be completed within a three-year period. In line with the central government's attempt to step out of detailed management of the energy sector, the Ministry of Energy was dissolved in 1993 and the Ministry of the Coal Industry and the Ministry of the Electricity Industry were reestablished. Many energy experts in China criticized this change however, saying that the government's role in energy planning and decisionmaking would be weakened and confused.

Under the new system, the SPC and the newly formed State Economic and Trade Commission (SETC) will coordinate policies across energy subsectors. The SPC will still be responsible for long-term planning and will also play a role in macroeconomic policy and project selection. Within the SPC, the Department of Energy Savings and Comprehensive Resource Utilization was dissolved, and the responsibility for energy conservation that once rested in that department has been transferred to the Department of Energy and Transportation within the SPC. The other responsibilities of the Department of Energy Savings and Comprehensive Resource Utilization have been transferred to the Department of Raw Materials within the SPC.

The SETC manages short-term production planning and supervises the current year's production of energy. The Bureau of Production Control manages the production of coal and oil. The Bureau of Energy Conservation and Integrated Utilization (within SETC) remains responsible for implementation of national energy-conservation activities and will probably play an even greater role in energy conservation in the future.

In addition, oversight of the energy corporations has shifted. Sinopec and the Nuclear Industry Corporation are under the leadership of the State Council. CNOOC is temporarily managed by the SPC.

The missions of the ministries of the coal and electricity industries have been scaled back to conform to market practices and are composed of activities related to planning, regulation, and 
standards. ${ }^{25}$ The 300-person staff at the Ministry of the Coal Industry is now only a third of its pre-reorganization size.

This most recent reorganization does not necessarily support the move to reduced government involvement in the sector. The number of government agencies has expanded, thereby increasing inefficiencies and overlaps; coordination is dispersed and the frequency with which the reorganizations take place inhibits long-term planning and policy implementation.

In 1994 the central government restructured its investment corporation structure, unifying all of them, including the SEIC, into a national development bank under the authority of the SPC. The exception to this is the Energy Conservation Investment Company (ECIC), which remains an independent development organization, also under the SPC. The mission of the ECIC may change somewhat in the future. It has been a major funder of projects that are economically attractive for enterprises to undertake on their own. The ECIC may move away from providing what are essentially development funds and concentrate on demonstration projects, perhaps including projects that conserve energy indirectly by using energy-intensive inputs, like steel, more efficiently. [62]

\section{Energy Trade}

China currently exports the equivalent of $4.1 \%$ of domestic energy consumption. ${ }^{26}$ Since 1986 , net oil exports have dropped dramatically. (Table 2-11). It is expected that China will become a net energy importer by 1995 and import levels will run about 40-50 Mt annually throughout the next decade. Much of the new oil imports are feeding growth in the new economic zones and areas along the coast. The higher levels of trade, as well as China's desire to become a member of GATT, have led it to undertake considerable reforms in trade policy to reduce state interference. No doubt exists that the rise in oil imports will have repercussions on domestic energy policies. Already, China is more active in exploring, developing, and investing in oil fields domestically and internationally. In addition, the government will be forced to look for effective ways to reduce future oil consumption through market instruments.

25 There are 13 departments in the ministry, including the Office of Minister, Department of Policy and Legislation, Department of Planning and Development, Department of Production Coordination, Department of Science, Technology and Education, Department of Coal Shipment Control, Department of Safety, Department of International Cooperation, Department of Accounting and Salary Control, Department of Human Resources, Department of Examination and Supervision, and Department of Approval and Data Statistics. The Ministry of the Electricity Industry has a similar bureaucratic structure.

26 Domestic energy consumption in recent years has been more than 10 billion tce. In 1991, China exported 59.2 Mtce of energy, including 27.4 Mt in crude oil and oil products and $20.1 \mathrm{Mt}$ in coal, and imported 16.2 Mtce of energy, including $10.6 \mathrm{Mt}$ in crude oil and oil products and $1.2 \mathrm{Mt}$ in coal. The net energy for export was 43 Mtce ${ }^{[3]}$. 
Table 2-11: Oil Imports and Exports (Mt), 1990-1992

\begin{tabular}{lrrl} 
& 1990 & 1991 & 1992 \\
\hline Exports & 29.3 & 27.4 & 26.9 \\
Imports & 6.1 & 10.6 & 19.0 \\
\hline
\end{tabular}

Source: China Statistical Yearbook 1992, China Statistics Press, Beijing, 1992. 


\section{THE OUTLOOK FOR CHINA'S ENERGY SYSTEM}

Regardless of what changes occur in China's political and economic systems, leaders must have good energy supply and demand forecasts on which to base their decisions. In this chapter we summarize the results of several energy and environmental forecasting models as they bear on energy demand and supply, energy-conservation potential, and greenhouse gas emissions; we also discuss the impacts of economic conditions, resources availability, environmental constraints, technology progress, and social concerns in the forecasting models. [52] Most of the forecasts reviewed are national in scope and were prepared for use in energy and environmental policymaking. We also comment on both the future of energy institutions and the potential for energy-technology cooperation between the United States and China.

\subsection{Energy Forecasting}

\section{Factors Affecting the Future of the Energy Sector}

Energy demand and supply forecasts depend critically on assumptions regarding the future. Below, we identify several key areas that affect the variables used in the forecasting models that have been applied to China.

\section{Economic Development}

The general level of economic growth in combination with expectations about improvements in overall energy efficiency can be employed to roughly indicate growth within the energy sector. Energy-forecasting analyses generally depend on economic activity indicators at various levels. All demand forecasting models incorporate assumptions regarding GDP growth. Assuming that China continues on its course of rapid economic expansion with continued average annual growth rates of $9 \%$ (similar to those witnessed during the 1980s), living standards will reach those of the current middle-income countries by the middle of the next century ${ }^{[1] 27}$. Yet even now the country has been feeling the repercussions of "too much too fast" and has already instituted a series of measures to dampen economic activity in certain areas in order to hold down inflation. The drastic energy shortages and transportation bottlenecks since the late 1980 s have already demonstrated the limitations of the energy sector's ability to expand to meet such large short-term demand. These concerns are reflected in official plans. After 2000, the central government intends to hold annual GDP growth to 4-5\% until 2020. Even assuming these lower rates, per capita levels of GNP would reach $\$ 4000-\$ 5000$ (1980 constant US dollars) by 2050 ,

27 Growth rates in 1991 and 1992 were $7 \%$ and $12.8 \%$, respectively. $[4,12]$ Many economists expect that the economic and income growth rates in this decade will be $8-9 \%$ and $7-8 \%$, respectively, or even higher for the rest of the decade. 
and overall GNP \$6.5-\$8 trillion, making China one of the future's global economic powerhouses.

\section{Energy Intensity of and Economic Output}

In recent years the overall energy intensity of the economy has dropped considerably, and in fact, has declined far beyond the expectations of many observers (see Figure 3-1). Elasticity of energy consumption dropped below 0.3 in 1993 . Some researchers believe that this may reflect a growing price elasticity of energy demand, that has come about as energy prices are gradually freed up, that could limit energy demand growth. ${ }^{61]}$ This implies that China may soon face a situation similar to that confronting US utilities beginning in the 1970 s, i.e., overly high projections of demand led them to build more capacity than was actually needed. The changing relationship between energy use and economic output, and the increasing reliance on prices to mediate that relationship need to be carefully examined. The assumptions regarding this relationship built into models must be kept clearly in mind when interpreting their results.

\section{Figure 3-1: Energy Intensity of GDP and National Income, 1978-1993}

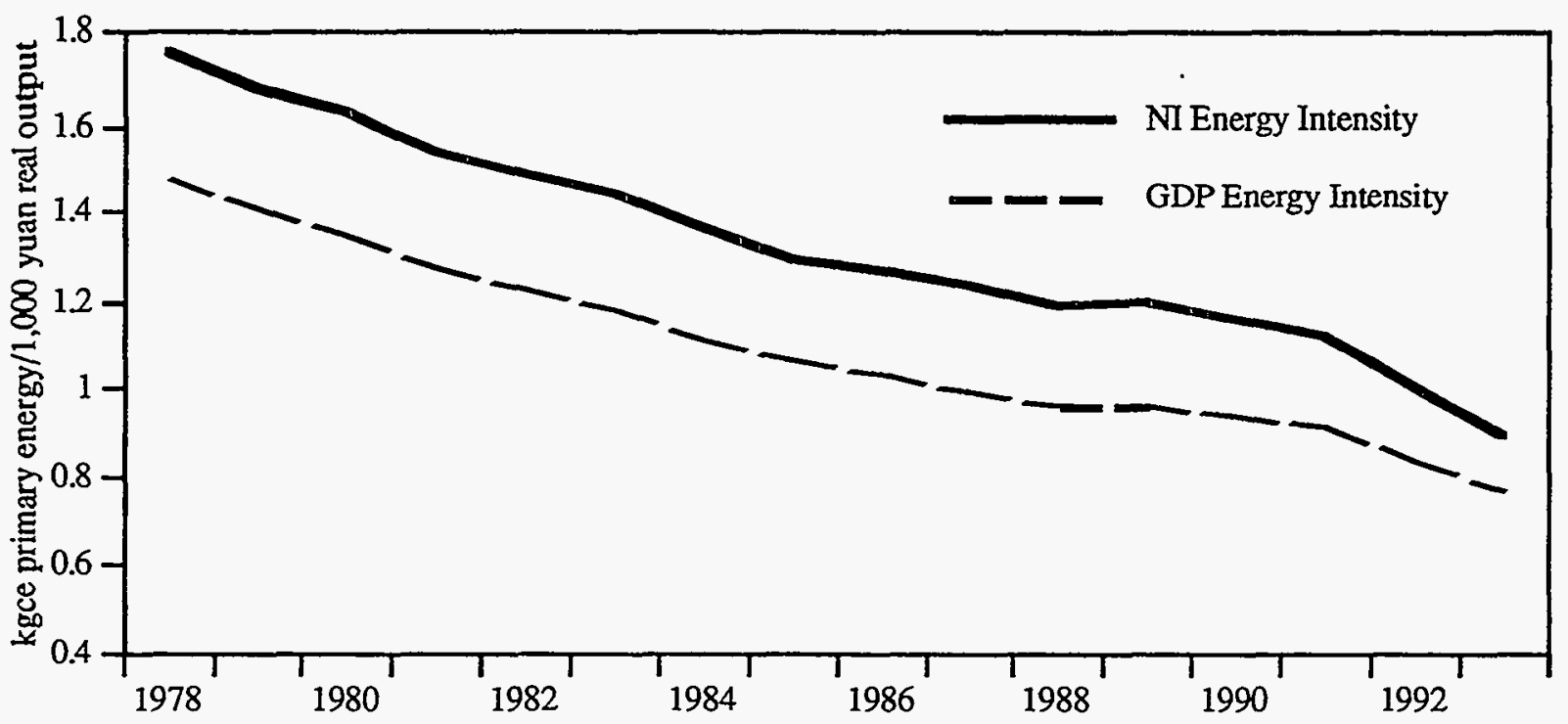

Source: Zhongguo Tongji Zhaiyao (Statistical Survey of China), China Statistics Press, 1994.

\section{Economic Structure}

One of the factors contributing to the decline in energy intensity in OECD economies was the move away from relatively energy-intensive economic activities to a service- and informationbased economy. Although China is aware of the energy-intensive nature of its industrial sector and has made efforts to reduce energy use in this area, the pace of structural change will also dictate future levels of energy consumption. One of the biggest concerns is the proliferation of 
small private enterprises and their increasing contribution to domestic output. 28 Although such growth is positive (increased flexibility, diversification) it also bodes poorly for future energy use, since many of these enterprises use energy much more inefficiently than large ones. It is unclear whether the proper macroeconomic signals and infrastructure will be in place to ensure that managers of small enterprises respond positively and improve the efficiency of energy utilization in their enterprises.

Currently, the residential and the commercial sectors account for a small portion of the total energy consumption, but a dramatic increase in energy demand is projected in the residential, commercial, and transportation sectors. Shortages of energy supply, however, will limit actual residential and commercial demand growth to more modest levels. Predicting what the actual growth in demand would be in the absence of shortages is difficult, although it is clearly higher than current forecasting may suggest. Some of the pent-up demand in rapidly growing sectors will be met with increased supplies of oil and liquefied natural gas, most of which will be supplied through increased imports. Although energy prices are critical to establishing a forecast, it is extremely difficult to incorporate price effects and energy-substitution effects in Chinese forecasting models.

\section{Population}

In addition to economic growth, the rate of population growth is one of the most significant factors affecting energy demand and consumption patterns. The sheer magnitude of China's base population (currently over 1.1 billion) means that even small percentage increases can dramatically effect future energy consumption as well as the demand for other services in the economy. Demographics are also critical. By 2020, the labor force and number of senior citizens are both expected to reach peaks of 1 billion and 300 million, respectively. The aggregate potential energy demand is one that is unparalleled in Chinese history. The Chinese government will continue to implement population control, but the reduction in centralized control will limit the effectiveness of such measures, particularly in rural areas where birth rates are higher.

\section{Urbanization}

Migration from rural to urban areas is also a large unknown factor when trying to understand future energy demand. Thus far, because of a relatively strict system of control over internal migration, the central government has been able to contain rapid increases in rural to urban migration. Economic development is almost inevitably accompanied by an increase in urbanization however, as the rural labor force moves to urban areas or forms new cities. Energy-

28 In 1980, state-owned enterprises accounted for 76\% of gross industrial output value. By 1991, the figure was slightly more than $40 \%$, the remainder produced by relatively small collective- and individual-owned enterprises. (China Statistical Yearbook, 1992) 
consumption patterns in urban areas differ considerably from those in rural areas. A transfer of population to urban areas will result in increasing demands for commercial energy.

\section{Resource Availability}

Although China has ample coal supplies, the use of this resource will become more and more complicated in an environmentally constrained world. Until now, the rate of expansion of coal and oil reserves (supply resources) has fallen short of population growth rates, but China's vast potential for energy efficiency improvements (demand resources) also needs to be taken into account when examining availability. The amount of non-energy resources such as cultivable land and fresh water is even more constraining.

Planners expect that coal will meet needs in most regions with the exception of Guangdong Province and some other coastal areas, ${ }^{[13]}$ yet overall shortages, especially of electricity, will persist. Oil security is expected to become a top priority for energy policymakers, especially as imports rise. The development of synthetic fuels is considered one of the main options for meeting the immensity of oil demand. [54]

Resource availability in the energy sector is dependent on both investment and technological progress. It is possible that private investment will gravitate to industries and sectors that offer higher rates of return or shorter payback times than the energy sector. Underinvestment in the energy sector exists now and could continue to be a problem in the future, but foreign investment may fill needed gaps, especially for development of oil and electricity.

\section{Environmental Constraints}

Economic development will be increasingly restricted by environmental conditions. The continued expansion of fossil fuel use could so considerably worsen air and water quality in urban areas that the higher costs of energy production could slow down economic growth. The degradation of forests could constrain the use of biomass in rural areas. It is important to improve on our assessments of environmental constraints and to incorporate them into the forecasts. Some models are used to show how the energy supply mix would differ at varying levels of carbon dioxide emissions.

\section{Political Factors}

While all these factors are important to help clarify China's future energy picture, political factors still have the biggest impact on the pace of China's economic transition and its future use of energy. Since the economic reforms are being led from the center, political attitudes are going to continue to be an important factor. Attitudes may not only be guided by how reforms contribute to economic growth, but may also depend on whether they allow for too much democratization in a still centralized political system. These political-economic linkages will also have an effect on the energy sector. 


\section{Energy Forecasts}

China initiated several studies on energy-forecasting methodology in the early 1980s. [53] Many of the models are notable for their practicality, ease-of-use, and policymaking orientation, which resulted from collaborations among model designers, energy experts, and policymakers. In particular, many models address the issue of $\mathrm{CO}_{2}$ emissions which will be of particular concern in the coming decades. In nearly all cases, model results clearly suggest that China's rapid economic expansion will require a substantial increase in energy use.

\section{Demand Forecasts}

Table 3-1 summarizes the results of the most recent major demand forecasts prepared in China. These primary energy demand figures are ranges based on the varying results of individual forecasts. ${ }^{29}$

Table 3-1: Domestic Energy Demand in the Long-Term Forecast

\begin{tabular}{lcccc} 
Energy Type & 1990 (actual) & 2000 & 2020 & 2050 \\
\hline Coul & & EJ & EJ & EJ \\
Oil & 22.03 & $29.3-32.23$ & $49.8-52.7$ & $71.6-86.6$ \\
Natural Gas & 4.83 & $5.86-7.32$ & $11.7-14.7$ & $20.5-29.3$ \\
Hydropower & 0.58 & $1.16-1.46$ & $3.80-4.68$ & $6.15-7.32$ \\
Renewwables* & 1.46 & $2.63-2.93$ & $5.27-6.44$ & $8.79-9.37$ \\
Nuclear Power & 0 & 0 & $0.14-0.29$ & $2.93-3.80$ \\
Total Commercial Energy & 0 & $0.29-0.41$ & $2.34-2.93$ & $8.79-13.18$ \\
Biomass & 28.91 & $42.2-45.4$ & $73.3-82.0$ & $117.2-128.9$ \\
Total Energy Demand & 7.70 & $8.79-10.25$ & $5.86-7.32$ & $1.46-2.93$ \\
& 36.62 & $51.3-55.7$ & $79.1-89.4$ & $118.7-131.9$ \\
& & & & \\
\hline
\end{tabular}

Note: Mtce $=$ million tons of standard coal equivalent; 1 Mtce $=2.93 \times 10^{16} \mathrm{~J}$.

* Does not include biomass.

Source: Fuqiang Yang and Mark D. Levine, "Modeling China's Energy Demand, Supply, and $\mathrm{CO}_{2}$ Emissions Futures: An Overview" LBL Energy Analysis Program, 1993 Annual Report, LBL-35240, forthcoming.

29 The forecasts were obtained from the following institutions, among others: the Energy Research Institute of the State Planning Commission and the Chinese Academy of Sciences; the Institute of Nuclear Technology, Qinghua University; the Institute of Energy System Analysis, Tianjin University; the Chinese Energy Research Society; the Energy Analysis Group of Zhejiang University; and the Center for Economic Development of the State Council. Each energy ministry, e.g., the Ministry of the Coal Industry and the Ministry of the Electric Power, has its own research institute (or group) carrying out forecast work. (These research groups continued to function throughout the periodic reorganizations of the energy sector administration.) For further information please see reference 52. 
Table 3-1 shows that overall primary energy consumption is forecast to rise from 1250 Mtce in 1990 to over 4000 Mtce in 2050 , which translates into an annual growth rate of $2 \%$-much lower than the $3.5 \%$ annual growth rate planners have targeted for economic growth in the same period. This rate represents a continuation of the current situation, in which elasticity of energy consumption has fallen well below unity. In the forecasts, energy-consumption elasticity stays relatively stable at about 0.6 between 1995 and $2050 .{ }^{30}$

Coal will still dominate the domestic energy mix. At least $50 \%$ of the total long-term energy demand will be served by coal; however the percentage of direct coal burning (as opposed to thermal power generation) will significantly decrease, in part due to limited expansion of transportation networks and more stringent environmental standards. Additionally, strong growth in oil demand (2.4\%-3.0\% average increase per year) will soon overwhelm domestic supplies, if it has not already.

Rural areas will continue to consume non-commercial energy in the near term, but most forecasts predict an eventual substitution of commercial energy for biomass. This substitution is reflected in a drop in non-conventional energy consumption from 300 Mtce in 2000 to 50-100 Mtce in 2050.

The forecasts for energy demand make several assumptions about sectoral development not reported in Table 3-1. Railroads will continue to dominate the transportation sector, although highway systems will receive an increasing share of the country's transportation burden. Private vehicles are assumed to develop faster than public transportation, while the energy consumption per ton-kilometer is predicted to decline considerably. Another important assumption is that residential energy in urban areas will be supplied almost entirely by gaseous fuels by 2050 . This would accompany an increase in the standard of living that allowed appliances for space heating, air conditioning, and cooling to become accessible to more of the population. Industry's share of economic output is expected to decrease, and the transportation and service sectors are expected to exhibit the most rapid economic growth.

In terms of final energy consumption, electricity demand will increase dramatically during this period and China will continue to face shortages of generation and distribution capacity in the long term. Average elasticity of electricity consumption between 1980 and 1990 was about 0.9 , much higher than for overall energy consumption. This parallels the experience of most developed countries during their developing stages, for which elasticities of electricity use were typically larger than 1. If we assume that China will follow this pattern in the 1990s, and if GNP grows at its target rate of $9 \%$ annually, installed capacity required to meet demand will need to be $325 \mathrm{GW}$ in 2000 . Carrying these same assumptions further into the future, installed capacities in 2020 and 2050 would be $640 \mathrm{GW}$ and $1800 \mathrm{GW}$, respectively.

30 It is projected that the energy elasticity in $1995-2000,2000-2020$ and $2020-2050$ would be $0.65,0.75$, and 0.6 . The commercial energy consumption elasticity would be about and even lower than 0.65 during the entire time period (2000-2050). 
For consistency with this trend, forecasts call for electricity generation's share of primary commercial energy consumption to increase from its current level of $25 \%$ to around $45 \%$ in 2050. Concurrent improvements in efficiency of energy transformation will have a positive effect on reduction of energy losses; energy consumption for the thermal power plants is assumed to decrease from $392 \mathrm{gce} / \mathrm{kWh}$ in 1990 to under $320 \mathrm{gce} / \mathrm{kWh}$ in 2050 . Forecasts are also highly optimistic about nuclear power development, which is expected to provide $300-450$ Mtce of primary demand by 2050 (although this conflicts with the supply forecasts presented following).

\section{Supply Forecasts}

Government agencies have performed energy supply forecasts up to the year 2000, although other forecasts extend much farther. The official projection for total primary energy supply in 2000 is shown in Table 3-2[54]

\section{Table 3-2: Official Supply Forecast for 2000}

\begin{tabular}{|c|c|c|c|}
\hline Energy Source & Supply (Raw Units) & Supply (Mtce) & Supply (EJ) \\
\hline $\begin{array}{l}\text { Raw Coal } \\
\text { Oil } \\
\text { Natural Gas }\end{array}$ & $\begin{array}{c}1.4 \mathrm{Gt} \\
200 \mathrm{Mt} \\
20 \text { billion } \mathrm{m}^{3}\end{array}$ & $\begin{array}{r}980 \\
280 \\
27\end{array}$ & $\begin{array}{r}28.71 \\
8.20 \\
0.79\end{array}$ \\
\hline Hydropower ${ }^{*}$ & $80 \mathrm{GW}$ & 88 & 2.57 \\
\hline Nuclear ${ }^{* *}$ & $5 \mathrm{GW}$ & 8 & 0.23 \\
\hline $\begin{array}{l}\text { Other } \\
\text { Total }\end{array}$ & 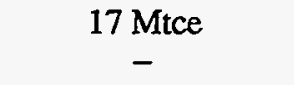 & $\begin{array}{r}17 \\
1400\end{array}$ & $\begin{array}{r}0.49 \\
41.02\end{array}$ \\
\hline
\end{tabular}

\footnotetext{
* Assuming hydropower capacity generates $250 \mathrm{TWh} / \mathrm{yr}$.

** On the assumption that nuclear power generates $25 \mathrm{TWh} / \mathrm{yr}$.

Mitce $=$ million tons of standard coal equivalent; $1 \mathrm{Mtce}=2.93 \times 10^{16} \mathrm{~J} ; \mathrm{EJ}=10^{18} \mathrm{~J}$
}

Source: Wu Zongxin et al., "Energy Demand Forecasting in the Year 2050," working paper, the Chinese Energy Research Society, Beijing, June 1990.

Installed generating capacity would reach $300 \mathrm{GW}$ in 2000 , more than half of which would be built in the 1990s. ${ }^{[55]}$ Based on the authors' electricity-demand predictions, there will be a shortage of at least $20 \mathrm{GW}$ of power generation capacity in 2000 . To reduce the gap between demand and supply, growth in electricity-generation capacity (or reduction in demand) needs to be $9 \%$ annually before 2000 and $5 \%$ annually before 2020 . Unofficial forecasts of energy supply also vary considerably, as shown in Table 3-3. 
Table 3-3: Domestic Energy Supply Forecasts through 2050

$\begin{array}{lcccc}\text { Energy Type } & 1990 \text { (actual) } & 2000 & 2020 & 2050 \\ & \text { EJ } & \text { EJ } & \text { EJ } & \begin{array}{c}\text { EJ } \\ \text { Coal }\end{array} \\ \text { Oil } & 22.59 & 29.30 & 44.0-48.1 & 66.95-77.35 \\ \text { Natural Gas } & 5.80 & 7.53-9.37 & 10.5-12.1 & 7.09-9.61 \\ \text { Hydropower } & 0.58 & 0.79-0.96 & 3.10-3.89 & 5.06-8.96 \\ \text { Renewables* } & 1.46 & 2.87-3.28 & 6.15-6.97 & 9.84-10.25 \\ \text { Nuclear Power } & 0 & 0 & 0.23-0.29 & 2.34-2.90 \\ \text { Total Commercial Energy } & 0 & 0.17-0.23 & 1.23-1.64 & 8.20-9.84 \\ \text { Biomass } & 30.44 & 40.4-42.2 & 65.0-73.0 & 99.62-119.0 \\ & & & & \\ \text { Total Energy Demand } & 7.70 & 8.20-9.37 & 4.39-5.27 & 1.46-2.93 \\ & 38.14 & 48.6-51.6 & 69.4-78.2 & 101.1-121.9\end{array}$

Note: Mtce $=$ million tons of standard coal equivalent; 1 Mtce $=2.93 \times 10^{16} \mathrm{~J}$.

* Does not include biomass.

Source: Fuqiang Yang and Mark D. Levine, "Modeling China's Energy Demand, Supply, and $\mathrm{CO}_{2}$ Emissions Futures: An Overview" LBL Energy Analysis Program, 1993 Annual Report, LBL-35240, forthcoming.

Among the forecasts, several assumptions are held in common. It is assumed that hydropower resources will be totally developed by 2050 , that coal will continue to dominate energy supply, that petroleum resources will be quickly depleted in the next two decades (necessitating imports), and that natural gas development will rise but still lag far behind demand. Forecasters also see environmental protection (specifically that of reducing the impacts of coal combustion) as a crucial factor in the acceleration of nuclear power development. A predicted $250 \mathrm{GW}$ of nuclear power capacity will be established by 2050 , accounting for $20 \%$ of the total electricity-generation capacity. Renewable energy development and energy efficiency will be relatively neglected compared to a conventional energy supply.

Within electricity generation, hydropower and coal-fired power will share $30 \%$ and $50 \%$ of the total electricity-generation capacity. A total of $80 \mathrm{GW}$ of hydropower will be developed in the 1990s, of which $43 \mathrm{GW}$ will be realized before 2000 . Long-range plans call for a total of $1900 \mathrm{GWh}$ of hydropower reserves to be built by 2050 . There are three hydropower bases: the upper and middle basins of the Yellow River (Huang He), the upper and middle basins of the Yangtze River (Chang Jiang), and the Pearl River (Zhu Jiang) basin. The Yellow River will provide peak load electricity for the northern region, including Beijing, Tianjin, and Hebei Province. Where possible, surplus amounts of electricity will be supplied to the eastern region near Shanghai. The Yangtze River, in the short term, will supply electricity for Sichuan Province and, in the long term will supply power to the south central and eastern regions, including Shanghai City. The Pearl River basin will supply the demands of Guangdong Province.

Total oil and gas reserves are estimated to be $100-110$ billion tons, of which $60-70$ billion tons are oil reserves. These reserves will be totally depleted sometime between 2030 and 2050 . 
Planners hope to commercialize coal gasification and liquefaction before 2030 as liquid fuel substitutes. Other energy products, particularly electricity, will also substitute for oil in the transportation sector.

\section{Carbon Dioxide Emissions}

Some analysts ${ }^{[54,56]}$ combined energy-demand models to forecast $\mathrm{CO}_{2}$ emissions. They predict emissions to be $0.81-0.85 \mathrm{Gt}$ of carbon (Gt-C) in 2000, 1.2-1.5 Gt-C in 2020, and 2.2-2.6 in 2050. These analysts argue that evaluations of alternative energy supply and end-use technologies should take into account both energy conservation and environmental improvement benefits and how these benefits influence energy supply, demand, and greenhouse gas emissions. They also feel that structural change in the economy and changes in end-use technology are likely to have a greater impact on $\mathrm{CO}_{2}$ emissions than fuel switching. In terms of average investment cost, it seems to be more cost-effective to reduce $\mathrm{CO}_{2}$ in China than in developed countries. ${ }^{[56]}$

\subsection{The Future of Energy Institutions}

As discussed in Chapter 2, the central government's energy institutions are playing less of a role in the day-to-day management of energy production and are becoming more concerned with questions of the adjustment to free-market conditions. Command and control regulation, with its associated bureaucracy, will not be as effective in the changing economic environment. Rather, the new tasks of government will require smaller, more integrated bodies that can evaluate developments and cross-cutting effects between energy subsectors.

With further development of the market economy, government control should center increasingly on improving the effectiveness of regulatory administration and less on administering and funding energy development. This in turn could bring about staff reductions in government entities that oversee energy institutions (SETC and SPC).

Breaking the Ministry of Energy into the Ministry of the Electric Power Industry and the Ministry of the Coal Industry definitely hampered the current movement toward market-based sectors, since it places institutional constraints on the government's ability to coordinate policies across subsectors. However, the inexorable push to market systems may eventually force a reworking and better integration of the current energy supply institutional structure.

The preponderance of central control and the lack (until recently) of non-governmental mechanisms to review energy policies have had detrimental effects on energy development. In particular, little regard was given to the environmental ramifications of rapid energy development or to China's sustained expansion of its coal base to fuel primary energy needs instead of the use of cleaner fuels such as natural gas. No useful comprehensive plan or policy 
yet exists to integrate and coordinate energy, environmental, and economic development.

Including larger numbers of energy policy experts in the 1980s in the governmental decisionmaking process has improved the effectiveness of policymaking considerably. Continuation of this trend would be beneficial, especially for long-term energy-strategy development, but such inclusion would also necessitate more openness regarding the successes and failures of past policies, something which all governments face with reluctance. It is difficult to tell whether a public hearing process would work effectively in China, but it is a model that might be considered.

\subsection{Impacts Beyond China's Borders}

\section{Greenhouse Gas Emissions and Acid Rain}

China currently accounts for about $10 \%$ of world energy consumption and about $11 \%$ of anthropogenic $\mathrm{CO}_{2}$ emissions. Both figures will surely rise over the coming decades, and China's participation in efforts to solve regional and global environmental problems will grow with them.

The Chinese government places much of the blame for the deterioration of the world environment on the currently developed countries, whose development was based on the consumption of massive quantities of fossil fuels. Even today, commercial energy consumption in developing countries (which have more than $60 \%$ of the world's population) is only onefifteenth of that in developed countries. The Chinese argue that for this reason developed countries should reduce their energy consumption and greenhouse gas emissions in order to provide developing countries leeway to expand their economies in the same fashion as the already developed countries. By this reasoning, the developed countries should bear the cost of environmental protection and reduction of industrial waste streams, including $\mathrm{CO}_{2}$ emissions. [57]

Such a perspective, however, should not be allowed to minimize the risk associated with pursuing current development practices. With the continuation of its coal-based development, China will remain the largest emitter of greenhouse gases in the developing world. Although per capita consumption in 2020 (1.2-1.8 tce) will still only be one-third to one-fourth current developed-country levels, the aggregate increases in $\mathrm{CO}_{2}$ emissions from such a growth will be tremendous. In order to meet the global stabilization targets envisioned in the 1992 Framework Convention for Climate Change, China will clearly need to reconsider its near-term position and consider stronger efforts toward emissions reduction.

To date, the Chinese government has expressed a great deal more concern and invested more resources in treating the local environmental impacts of pollutants from fossil fuel combustion$\mathrm{SO}_{\mathrm{x}}, \mathrm{NO}_{\mathrm{X}}$ and particulate-than greenhouse gases. There are still internal arguments over whether global climate change will really cause significant damage, so the Chinese government 
is reluctant to invest its limited capital in reducing greenhouse gas emissions. This also reflects the prevailing opinion in government decisionmaking circles that a stronger economy better enables a country to protect its environment. "Wait and see" is the government's strategy to answer the risk of global warming. Energy conservation and other "no regrets" improvements in technology are thought to be the best ways to cope with this uncertainty.

In addition to greenhouse gas concerns, China's combustion of high-sulfur coal (mainly in the Southwest) has worsened acid precipitation both in China and in Southeast Asia. Acid rain $(\mathrm{pH}<5.0)$ frequently occurs in Sichuan and Guizhou provinces. Moreover, due to prevailing wind patterns, emissions from the heavily industrialized Northeast are carried to Japan and Korea. Although the Chinese government is aware of these problems, capital constraints have prohibited it from purchasing desulfurization equipment for plants in the south. (Average cost for installing desulfurization technology in a power plant is about US $\$ 400$ million.) To date, only one coal-fired power plant, located in Chongqing in Sichuan Province, has incorporated desulfurization units. Japan has already indicated that it will begin to install desulfurization technology in China's coal plants in the Shandong peninsula as a test project, but this will not address the huge costs (up to $\$ 80$ billion) of widespread dissemination of such technologies. Improved cooperation is definitely needed. ${ }^{31}$.

\section{Impacts on World Energy Markets}

China will become a net energy importer by 1995 if it is not already. By relying almost entirely on domestic energy development, the country's economy had grown at a relatively high rate for more than four decades. Such growth will clearly not be sustainable for long, and China will soon be forced to expand its presence in international energy markets.

The reduction in oil exports is already a visible trend and crude oil imports should rise in the future. Already China has signed a contract with Saudi Arabia for the delivery of 21 million tons of oil per year (July 1993). By the year 2000, oil imports will reach 40-50 Mt per year, equivalent to $0.7-1.0$ million barrels per day, or 2-3\% of total international oil transactions. This is unlikely to have a substantial effect on world oil prices, but China's oil imports in the next decade may change the patterns of oil trade flows, especially if China cannot discover and develop significant new oil fields. If China's oil imports continue to increase beyond 2000 , the impact on the world oil markets will be no longer be small by the year 2020 .

China will probably be the largest consumer of Siberian oil. LPG is in great demand in the Chinese market. Fifty to sixty billion cubic meters of natural gas will be imported from Siberia, about $20 \%$ of total trade in LPG, and this will exert considerable influence on the international market. The uncertainties regarding LPG center on supply availability and the stability of long-

31 Christian Science Monitor, "Japanese Link Increased Acid Rain to Distant Coal Plants in China", November 6, 1992. 
term contracts rather than the demand and purchase capability.

Drawing on it, rich coal reserves, China will export more coal to the Japanese, South Korean, and Southeast Asian markets. Unless increases in coal production costs can be controlled however, Chinese coal will not be competitive. Because of shortages in transportation capacity and of some types of coal, China's coastal areas will import a small amount of coal from other countries, mainly Australia.

With the development of hydropower in the remote Southwest, China may be in a position to export electricity to Southeast Asia. Central government and provincial plans also call for nuclear power stations to become a major share of installed capacity. If these plans are realized, 20-30\% of electricity generation will come from nuclear plants in 2020. Unless there are unexpected discoveries of new uranium reserves, concentrated uranium fuel will have to be imported. Future international political configurations will therefore have a large impact on the availability of uranium fuel.

\subsection{Prospects for Collaboration between China and the United States}

Great potential exists for collaboration on energy and environmental issues between China and the United States. The two countries share some features and patterns of energy production and consumption.

\section{Clean Coal Technology}

China and the US are the two largest producers and consumers of coal, thus coal-related environmental pollution requires significant attention in both countries. In recent years the Chinese have shown great interest in US clean coal technology programs on both the R\&D and policy levels. The US Department of Energy (DOE) is currently proposing $\$ 50$ million in aid to China to help reduce the incremental cost of transition from conventional coal combustion to combined-cycle coal gasification power plants, although the actual total that will pass through Congress will probably be much lower. DOE is discussing a possible joint US-China effort to build an advanced coal gasification/combined-cycle power plant in China. It has also sponsored coal technology trade missions and reverse trade missions in this area. Such missions included educational components regarding coal safety and the recovery of coal-bed methane and safe coal storage. [60]

Cooperation in integrated utilization of coal will significantly reduce emissions in China and consequently carry with it global benefits. Rapid growth in electricity generation also opens doors for American manufacturers of generation and transmission equipment. 
Energy conservation, stimulated by the implementation of integrated resource planning, utility demand-side management, and competition in electricity supply may be introduced into and employed in the Chinese electricity industry to improve generation efficiency and reduce use.

Export and licensing to China of efficient end-use technologies developed in the US, such as variable-speed motors, efficient lighting, and equipment specific to various industrial processes, holds great promise as well. Table 3-4 compares the energy consumption per unit output for some principal energy-intensive products in which American technology could be extremely valuable for reducing energy consumption in Chinese industry [58].

Table 3-4: Comparison of Energy Consumption for Chinese and US Products, 1990

\begin{tabular}{|c|c|c|c|}
\hline Sector and Product & Unit & Chinese Product & US Product \\
\hline $\begin{array}{l}\text { Electricity Transmission } \\
\text { Losses }\end{array}$ & percent (\%) & 8.06 & $6.2^{\dagger}$ \\
\hline $\begin{array}{l}\text { Synthetic Ammonia } \\
\text { (natural gas, large plants) }\end{array}$ & GJ/ton & 37.8 & $27.2-29.3$ \\
\hline Ethylene (large plants) & GJ/ton & $37.4-43.7$ & 19.6 \\
\hline Soda & GJ/ton & 44.7 & 41.8 \\
\hline Freight Transport & $\mathrm{MJ} / \mathrm{km} / \mathrm{ton}$ & $\begin{array}{l}\text { diesel: } 1.62 \\
\text { gasoline: } 2.47\end{array}$ & diesel: 1.14 \\
\hline
\end{tabular}

$\uparrow 1989$ figure.

Source: Foreign Energy Consumption Data for Major Energy Intensive Products, Chinese Energy Research Society, Beijing, January 1993.

In a recent development, DOE, the Worldwide Fund for Wildlife, and the Energy Research Institute (under China's SPC) opened the Beijing Energy Efficiency Center (BECon) in December of 1993. BECon's mission is to develop energy efficiency policies and joint USChina business ventures to aid China's transition to an energy-efficient economy. BECon holds the potential to facilitate the transfer of appropriate US efficiency technology to China. The Center's activities will include energy efficiency policy analysis and formulation, energy efficiency business development, energy sector professional training, and providing information regarding energy efficiency measures to the public. Both Lawrence Berkeley Laboratory and Battelle, Pacific Northwest Laboratory, have been involved as founding US members and are working to facilitate US-China contacts in the area of energy efficiency. 
Renewable Energy Sources

China's immense hydropower resources have been the mainstay of installed renewable energy capacity. Harnessing of hydropower resources, however, is expected to level off in the near future. The Chinese government, in turn, has been pursuing other forms of renewable energy development. Since the late 1970s, biomass and solar energy R\&D development has led to the development of biogas digesters and solar cookstoves.

Wind energy, however, is an area in which the Chinese are looking to the US for R\&D sharing and technology transfer. Similarly, American private firms and DOE have become interested in the Chinese renewable technologies market as evidenced by a recent mission of US renewable technology representatives to China that broke the ground for US-China collaborations in renewable energy. Already a joint venture between the Ministry of the Power Industry and Zond Systems, an American firm, will help establish advanced wind turbinemanufacturing capabilities in China and should account for $500 \mathrm{~kW}$ of installed capacity by 2000.

\section{Nuclear Power}

China has ambitious goals for nuclear power development and expects to build up to $6 \mathrm{GW}$ of nuclear capacity by 2000 and $20 \mathrm{GW}$ by 2020 . The investment in capacity will be focused on the coastal regions that lack access to coal due to transportation bottlenecks. These areas include Guangdong, Hainan, Fujian, Zhejiang, Jiangsu, Shandong, and Liaoning provinces.

Since there are many obstacles to further nuclear power development in the United States, the Chinese market provides potentially good opportunities for participation by American companies. Until now, except for the Daya Bay project, the Chinese government has not instituted any blanket policy allowing for foreign investment in the country's nuclear power industry. The capital-intensive nature of nuclear power development, however, could necessitate a more radical shift in this area. The potential for cooperation also depends on the status of US export restrictions on nuclear-generating technology.

\section{Petroleum Development}

American energy corporations are already extensively involved in China's offshore and inland oil and natural gas development. Over the past year and a half, the Chinese government has accepted several bids by US companies to explore various tracts of the East and South China seas, the Tarim Basin in Xinjiang, and areas within Hunan province. 
Economic losses caused by acid rain run more than 10 billion yuan annually. In 1992, a total of 19.5 million tons of sulfur dioxide was emitted and the average annual increase in emissions for the last eight years has run about 3.8\%. Before 2000, China is expected to surpass developed countries in $\mathrm{SO}_{2}$ emissions and reach levels of 28 millions tons by $2000{ }^{[59]}$.

In 1991, thermal power plants, particularly coal-fired power plants, emitted a total of 4.6 million tons of $\mathrm{SO}_{2}$, which indicates that power plants are the major $\mathrm{SO}_{2}$ emitters in China. Table 3-5 shows the Chinese central government desulfurization plan and the total capital requirements for the period 1996-2000. Desulfurization projects should be accompanied with decreases in dust and toxic pollutants in power plants. As noted previously, desulfurization technology holds much promise as an area of US-China technology cooperation.

Table 3-5: Desulfurization in Thermal Power Plants during 1996-2000

\begin{tabular}{lccccccc} 
& Units & 1996 & 1997 & 1998 & 1999 & 2000 & Total \\
\hline Desulfurization & M tons & 0.3 & 0.6 & 0.9 & 1.2 & 2.0 & 50 \\
Related Capacity & GW & 8.6 & 12.9 & 17.2 & 25.8 & 43 & \\
Capital Requirement & B yuan & 1.875 & 1.875 & 1.875 & 1.875 & 5 & 12.5 \\
\hline
\end{tabular}

Source: Liu Xueyi, "Desulfurization in the Power Industry," working paper, Energy Research Institute, Beijing, October 1993. 


\section{REFERENCES}

N.B. These references follow the Chinese convention for ordering of Chinese names, i.e., surname appears first.

1. "Reform Accelerating Economic Development," People's Daily [domestic edition] October 20, 1993.

2. A Statistical Survey of China, 1993, China Statistics Press, 1993.

3. China Statistical Yearbook China Statistics Press, Beijing, 1992 and 1993.

4. China Energy Databook, 1992 Edition, Jonathan E. Sinton, et al., eds., LBL-32822, 1993.

5. Huang Zhijie, "Analysis of China's Energy and Environmental Policy During the Planning System," working paper, June 1993.

6. "Deng Xiaoping meets with Spanish Vice Premier", People's Daily [domestic edition], April 30, 1980.

7. Liu, Zhiping, Fuqiang Yang, Jonathan E. Sinton, and Mark D. Levine. Energy Conservation Investment Programs in China during the Seventh Five-Year Plan (1986-1990). forthcoming, 1994.

8. Mark D. Levine and Liu Xueyi, "Energy Conservation Programs in the People's Republic of China," LBL report, No. 29211, August 1990.

9. "China Will Adopt BOT to Attract Foreign Investors", People's Daily [domestic edition], April 23, 1993.

10. Wang Xirong, "History of Huaneng Corporation," presentation at U.S.-China Conference on Energy, Environment, and Market Mechanisms, LBL, Berkeley, October 29-30, 1992.

11. Huaneng Corporation, brochure, Huaneng, 1993.

12. Energy and Environment-References for Energy Policy and Planning, Vol. 8, edited by Wang Qingyi, Ministry of Energy and Chinese Energy Research Society, February 1992.

13. "Adopt New Measures for the Development of Energy-Forum of Senior Advisors of Ministry of Energy, Section 1", Energy of China, pp. 8-10, No. 1, 1992.

14. "Adopt New Measures for the Development of Energy-Forum of Senior Advisors of Ministry of Energy, Section 2", Energy of China, pp. 1-3, No. 2, 1992.

15. Wang Qingyi, "Analysis of Energy and Environment Policy in Transition Period," working paper, the Chinese Energy Research Society, 1993.

16. Gao Zhengzhu, "Effect Analysis of Fund Collection Policy in the Electricity Industry and Some Suggestions," working paper, the Chinese Energy Research Society, 1991.

17. Zhang Aling, "Energy Analysis and Forecasting", U.S.-China Conference on Energy, Environment, and Market Mechanisms, LBL, Berkeley, October 29-30, 1992.

18. "Transportation Situation in China," World Daily [Chinese edition], March 23, 1993.

19. China's Energy Statistical Summary in 1991, China Statistics Press, 1992.

20. Peng Shiji and Sun Jiangming, "Problems and Strategy for Development of Coal Resources," Energy Policy Research, the Ministry of Energy, August, 1992. 
21. Bian Xuehai and Sun Xihua, "Electricity Base and Strategy for Economic Development in Shanxi," Energy of China, Vol. 24, No. 12, pp. 29-31, December 1991.

22. "Accelerating Power Development by Expanding Foreign Investment", People's Daily [domestic edition], December 13, 1993.

23. Ibid.

24. Handbook of Rational Resource Utilization, edited by the Department of Resources and Integrated Utilization, State Planning Commission, China Science and Technology Press, 1992.

25. Gao Zhengzhu, "Effect Analysis of Fund Collection Policy in the Petroleum Industry and Some Suggestions," working paper, the Chinese Energy Research Society, 1991.

26. "Construction for Nuclear Power Stations for the Coming Decades, People's Daily, [domestic edition], December 17, 1993.

27. "Oil Price Gradually Released", People's Daily [domestic edition], December 31, 1992.

28. Coal Price in China, Liu Guangwen, et al., eds., Chinese Planning Press, 1990.

29. Miao Guoliang, "How to Make Sound Combination of Planned Economy with Market Regulation for Coal Production," Market Economy and China Energy Development Strategy, Nuclear Energy Press, December, 1992.

30. Ding Zhao, "Consideration and Assumption on the Reform of Coal Price," Market Economy and China Energy Development Strategy, Nuclear Energy Press, December, 1992.

31. Yu Cong, "Lessons on Energy Import Export Policies" Chinese Energy Research Society, Report on Energy Policy Analysis, July, 1992.

32. China Refinery Technology, edited by Xianling Hou, China Petroleum Press, Inc., December 1991.

33. Ding Zhao, "Consideration and Assumption on the Reform of Coal Price," Market Economy and China Energy Development Strategy, Nuclear Energy Press, December 1992.

34. Zhou Fengqi, "Energy Conservation Progress in China," Energy, No. 1, 1989.

35. Dai Yande, et. al., "An Analysis of the Potential in Investment-Cum-Energy Conservation in the Chemical Industry in China," working paper, Energy Research Institute, Beijing, June, 1992.

36. Zheng Guanan, "Reconsideration for Energy Conservation in the Chemical Industry", Energy of China, No. 9, 1992.

37. Marc Ross and Liu Feng, "The Energy Efficiency of the Steel Industry of China," Energy, Vol. 16, No. 5, pp. 833-848, 1991.

38. Liu Zhiping, et al., "The Investment-Energy Conservation Curve of the Iron and Steel Industry of China," working paper, Energy Research Institute, Beijing, June 1992.

39. Hu Xiulian, "Analysis of Energy Consumption in Electricity Generation", Energy Analysis on Energy Consumption for Major Domestic and Foreign Products, Guangming Daily Press, pp. 54- 73, December, 1988.

40. Zhao Yuying, "Analysis of Technology Renovation during the Seventh Five Year Plan," 
Energy Analysis on Energy Consumption for Major Domestic and Foreign Products, Guangming Daily Press, 1988.

41. Ye Qing, "Outlines of the Fifth Conference of Energy Conservation: Report for Energy Conservation Office, the State Council," Energy, No. 5, 1989.

42. Qin Shiping, "Evaluation of Technology Renovation during the Sixth Five Year Plan," Paper Selection on Energy Conservation during the Sixth Five Year Plan, Energy Press, 1989.

43. Jian Xianrong, "Review and Prospective for China's Energy Conservation," Energy Journal, No. 5, 1989.

44. Zhu Liangdong, "Achievement of Energy Conservation in the Past Decade and Targets of the Future," Energy Journal, No. 10, 1991.

45. Zhu Liangdong, "Overview and Prospects for Energy Conservation," in National Energy Conservation Propaganda Week, pp 1-18, State Planning Commission, October, 1991.

46. Department of Policy, Regulations and Systems, Ministry of Electric Power, "Problems and Policies in the Development of the Power Industry, China Energy, Vol. 46, No. 10, pp 5-9, October, 1993. [Note: The Department of Policy, Regulations and Systems was formerly referred to as the Office of Policy and Regulation. The use of the word "systems" has been added to indicate that the office is now responsible for overseeing the Ministry's response to the transition from a planned to a market system.]

47. Li Qicang, "Ecological Agriculture and Output Growth," Paper Collection for the Third National Conference of Rural Energy, 1988.

48. Integrated Planning and Implement for Rural Energy, Qiu Daxiong et al., eds., Qinghua University Press, October, 1991.

49. National Planning for Rural Energy Regionalization, Xu Xichun and Zhang Zhengmin, eds., China's Statistics Press, October 1990.

50. Deng Keyun, "Coordinative Development of Economy, Energy and Ecology in Rural Areas," Market Economy and Energy Strategy, pp 62-68, Nuclear Energy Press, December, 1992.

51. Shi Yong et al., "Improving the Competition of the Petrochemical Industry for as a basis for Complying with GATT Entry Requirements, China Energy. Vol. 44, No. 8, pp. 26-31, Aug. 1993.

52. Yang Fuqiang and Mark D. Levine, "Modeling China's Demand, Supply, and $\mathrm{CO}_{2}$ Emissions Futures: An Overview," Energy Analysis Program 1993 Annual Report, LBL-35240, forthcoming.

53. Development and Application of Energy Forecasting Models, edited by the Department of Energy Conservation, State Planning Commission, China Planning Press, July 1987.

54. Wu Zongxin et al., "Energy Demand Forecasting in the Year 2050," working paper, the Chinese Society of Energy Research, June 1990.

55. "China Will Build Nuclear Power Plants Along Coastal Areas", World Daily [Chinese 
edition], March 1, 1994.

56. Xi Xiaolin, "Energy Development and $\mathrm{CO}_{2}$ Emission in China," $\mathrm{Ph} . \mathrm{D}$. dissertation, Department of Engineering and Public Policy, Carnegie Mellon University, March 1993.

57. Zhu Chengzhang, "Perspective of China's Energy and Environmental Policies," working paper, April 1993.

58. Foreign Energy Consumption Data for Major Energy Intensive Products, Chinese Energy Research Society, Beijing, January 1993.

59. Liu Xueyi, "Desulfurization in the Power Industry," working paper, Energy Research Institute, Beijing, October 1993.

60. Ted Atwood, US Department of Energy, Clean Coal Technology program, personal communication, 8 March, 1994.

61. Wang Qingyi, Deputy President, China Energy Research Society, personal communication, 22 April 1994.

62. Fan Rongyi, Section Chief, Energy Conservation Corporation, personal communication, 29 April 1994.

63. Jonathan E. Sinton, Energy Analysis Program, Lawrence Berkeley Laboratory, interviews at cement factories in southern Jiangsu Province, May-June, 1994.

64. Vaclav Smil, China's Environmental Crisis: An Inquiry into the Limits of National Development, Armonk, NY: M.E. Sharpe, 1993.

65. Cui Fengwen, Division Chief, Planning Department, Sinopec, personal communication, 10 August 1994. 


\section{APPENDIX}

Exchange Rates, 1980-1992

Chinese yuan (Renminbi) per US dollar

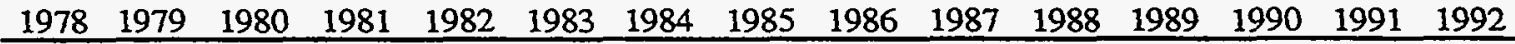

$\begin{array}{lllllllllllllll}1.58 & 1.50 & 1.53 & 1.75 & 1.92 & 1.98 & 2.80 & 3.20 & 3.72 & 3.72 & 3.72 & 3.77 & 4.78 & 5.32 & 5.75\end{array}$

Note: These exchange rates are median values for each year.

\section{Energy Conversion Factors}

\begin{tabular}{llll} 
& GJ & MBtu & toe \\
\hline & & & \\
1 tce & 29.29 & 27.76 & 0.654 \\
\hline
\end{tabular}

